Florida International University FIU Digital Commons

FIU Electronic Theses and Dissertations

University Graduate School

$11-12-2013$

\title{
Aspects of the Innate Immune System in the Caribbean Octocoral Swiftia exserta
}

Lorenzo P. Menzel

Florida International University, lorenzo.menzel@fiu.edu

DOI: $10.25148 /$ etd.FI13120907

Follow this and additional works at: https:// digitalcommons.fiu.edu/etd

Part of the Biochemistry Commons, Cell Anatomy Commons, Cell Biology Commons, Enzymes

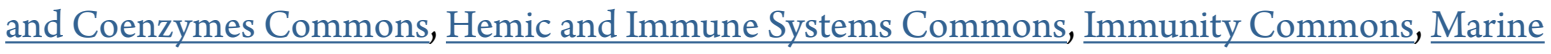
Biology Commons, and the Tissues Commons

\section{Recommended Citation}

Menzel, Lorenzo P., "Aspects of the Innate Immune System in the Caribbean Octocoral Swiftia exserta" (2013). FIU Electronic Theses and Dissertations. 1025.

https://digitalcommons.fiu.edu/etd/1025

This work is brought to you for free and open access by the University Graduate School at FIU Digital Commons. It has been accepted for inclusion in FIU Electronic Theses and Dissertations by an authorized administrator of FIU Digital Commons. For more information, please contact dcc@fiu.edu. 


\title{
FLORIDA INTERNATIONAL UNIVERSITY
}

Miami, Florida

\section{ASPECTS OF THE INNATE IMMUNE SYSTEM OF THE CARRIBEAN OCTOCORAL SWIFTIA EXSERTA}

\author{
A dissertation submitted in partial fulfillment of the \\ requirements for the degree of \\ DOCTOR OF PHILOSOPHY \\ in \\ BIOLOGY \\ by \\ Lorenzo P. Menzel
}

2013 


\section{To: Dean Kenneth Furton}

College of Arts and Sciences

This dissertation, written by Lorenzo P. Menzel, and entitled Aspects of the Innate Immune System in the Caribbean Octocoral Swiftia exserta, having been approved in respect to style and intellectual content, is referred to you for judgment.

We have read this dissertation and recommend that it be approved.

M. Alejandro Barbieri

John Makemson

J. Martin. Quirke

Sylvia L. Smith

Charles H. Bigger, Major Professor

Date of Defense: November 12, 2013

The dissertation of Lorenzo P. Menzel is approved.

Dean Kenneth Furton

College of Arts and Sciences

Dean Lakshmi Reddi

University Graduate School

Florida International University, 2013 
(C) Copyright 2013 by Lorenzo P. Menzel

All rights reserved. 


\section{ACKNOWLEDGMENTS}

I wish to thank the members of my committee for their support, patience, and good humor during some very trying times. They selflessly shared reagents, protocols, equipment, and advice; their help has been most appreciated.

From my days (years, nearly decades, really) at UCLA I am still indebted to Robert I. Lehrer, Sylvia S.L. Harwig, In-hee Lee, Alan Waring, and Tom Ganz for introducing me to the fascinating world of antimicrobial peptides and their associated techniques; and to Birgitta and Fritiof Sjostrand, and Alicia Thompson for showing me the wonders of electron microscopy.

At FIU I thank Armando Perez at Scientific Receiving for his diligence and thoughtfulness; the Inter-Library Loan staff for tirelessly finding reprints; the Biology Main Office staff (Helen Furlong and Eliana Guzman); FSRTA and QBIC staff (Aileen Soto, Isabel Sifuentes, Grisel Freire, Mevis Hidalgo, Amy Reid, Jenn Seda, Xiera Itayem); Nichole Hinds Vaughn and Liza Merly for moral and technical support; Herman Jordan, Ghalib Carmichael, and Ed, Mike, and Mindy Szrejter for judo support; Todd and Deanna Miller for 912 support; and Jeff Wells for innumerable career advising sessions. To my collaborators, Barry Stein at Indiana University for patiently taking yet another set

of electron-micrographs, and Kym Faull at UCLA for allowing me to visit his lab, use his mass spectrometers, and his time, I extend my heartfelt thanks.

Bob Lehrer deserves another mention for his prodding support and for setting a standard I still aspire to meet, not only with his science but also with his writing. 


\section{ABSTRACT OF THE DISSERTATION \\ ASPECTS OF THE INNATE IMMUNE SYSTEM IN THE CARRIBEAN \\ OCTOCORAL}

SWIFTIA EXSERTA

by

Lorenzo P. Menzel

Florida International University, 2013

Miami, Florida

Professor Charles H. Bigger, Major Professor

The immune systems of cnidaria are important to study for two reasons: to gain a better understanding of the evolution of immune responses, and to provide a basis to partially redress the precipitous world-wide die-offs of reef corals, some of which have been attributed to diseases and stress. Many immune responses share ancient evolutionary origins and are common across many taxa.

Using Swiftia exserta, an azooxanthellate ahermatypic local octocoral, as a proxy model organism to study aspects of innate immunity in corals and cnidaria allows us to address both of the reasons listed above while not using endangered species. Utilizing a coral that does not contain symbiotic dinoflagellates (zooxanthellae) simplifies the system by restricting the source of proteins to a single genome. The lack of zooxanthellae in Swiftia exserta also allows the animal's simple adaptation to lab settings.

This study of the innate immune system of an octocoral demonstrates: 1) a novel understanding of the microanatomy of octocoral tissues; 2) that Swiftia exserta has at least two cell types that function as constitutive immunocytes; and 3) the presence of two 
potent antibacterial peptides, one with a mass between 4694 and 4696 Daltons. My report on the microanatomy of the coenenchyme, the tissue between polyps, advances the understanding of octocoral anatomy by systematically comparing histology sections with electron micrographs. Applying various techniques of enzyme histochemistry, coupled with cryo-preservation, to the coenenchyme I have identified at least two populations of constitutive immunocytes in Swiftia exserta. Two antibacterial proteins are identified by protein purification and antimicrobial testing techniques. The more active protein is partially characterized with modern hyphenated mass-spectrometry techniques, and can be the focus of future study. 


\section{TABLE OF CONTENTS}

CHAPTER

PAGE

I. Introduction

1

References

II. Histology and Ultrastructure of the Octocoral Swiftia exserta, A Model Organism for Innate Immunity/Graft Rejection

A. Introduction

B. Materials and Methods

C. Results

D. Discussion

References

24

Appendix I (figs for this chapt)

III. Initial Functional Characterization, by Enzyme Histochemistry, of the Immunocytes in Swiftia exserta, an Octocoral

A. Introduction

B. Materials and Methods

C. Results

D. Discussion

References

Appendix II (figs for this chapt)

V. Swiftin, a Broad-Spectrum Antibacterial Peptide from an Azooxanthellate Octocoral

A. Introduction

B. Materials and Methods

75

C. Results

83

D. Discussion

References

91

Appendix III (fig for this chapt.)

98

VI. Conclusion

105

References

108

Appendix IV

109

VITA

110 


\section{LIST OF FIGURES}

FIGURE

Chapter 2 Figure 1a. Swiftia exserta colony in an aquarium

Chapter 2 Figure 1b. Cut branch, with centimeter scale

Chapter 2 Figure 2. Schematic octocoral diagram

Chapter 2 Figure 3. Coenenchyme and ectoderm micrographs

Chapter 2 Figure 4. Cell cords in the coenenchyme

Chapter 2 Figure 5. Mesoglea with assorted cell and cell cords

Chapter 2 Figure 6a-e. Solenia-type endo/gastroderm

Chapter 2 Figure 6f-h. Solenia-type endo/gastroderm, continued

Chapter 3 Figure 1. Normal Tissue, stained paraffin and control cryo-section

Chapter 3 Figure 2. Acid phosphatase micrographs

Chapter 3 Figure 3. Non-specific esterase micrographs

Chapter 3 Figure 4. Diaminobenzidine peroxidase micrographs

Chapter 3 Figure 6. Quinone and quino-protein stain micrographs

Chapter 4 Figure 1b. Antibacterial screening gel-overlay assay

Chapter 4 Figure 2. Graph of typical radial diffusion antimicrobial assay of fractionated Swiftia exserta extract

Chapter 4 Figure 3. Silver-stained SDS-PAGE of Swiftia exserta extract and Major Active Fraction, swiftin 
Chapter 4 Figure 4. FT-MS m/z ion trace of fraction 76

Conclusion Figure 1. Swiftia exserta host defense schematic 


\section{LIST OF ABBREVIATIONS AND ACRONYMS}

Figure Abbreviations

$\begin{array}{ll}\text { ae } & \text { axial epithelial cells } \\ \text { ax skel } & \text { axial skeleton } \\ \text { des } & \text { basal lamina-like structure surrounding solenia gastroderm } \\ \text { EcD } & \text { desmocyte plaques } \\ \text { EnD } & \text { Ectoderm } \\ \text { GaD } & \text { Gastroderm } \\ \text { ga } & \text { granular amoebocyte } \\ \text { mor } & \text { morula-like cell } \\ \text { M } & \text { Mesoglea } \\ \text { mc } & \text { mesogleal cell } \\ \text { nem II } & \text { type II nematocyst, atrichous isorhiza } \\ \text { og } & \text { oblong granular cell } \\ \text { sol } & \text { solenia } \\ \text { sclerocyte } & \\ \text { spicule }\end{array}$


Text Abbreviations

\begin{tabular}{|c|c|}
\hline APS & Ammonium persulfate \\
\hline AU & Acetic acid-Urea \\
\hline BLAST & Basic Local Alignment and Search Tool \\
\hline $\mathrm{BCA}$ & Bicinchoninnic acid \\
\hline cDNA & complementary DNA \\
\hline $\mathrm{Da}$ & Dalton, the atomic mass unit \\
\hline DAB & DiAmino Benzidine \\
\hline DNA & Deoxyribonucleic acid \\
\hline DOPA & L-dihydroxy L-phenylalanine \\
\hline EDTA & EthyleneDiamineTetraAcetic acid, chelates $\mathrm{Ca}^{2+}, \mathrm{Mg}^{2+}$ \\
\hline EGTA & Ethylene Glycol Tetra Acetic acid, chelates $\mathrm{Ca}^{2+}$ \\
\hline ESI & ElectroSpray Ionization \\
\hline FSW & Filter-sterilized Sea Water \\
\hline FT & Fourier Transform \\
\hline H\&E & Hematoxylin and Eosin \\
\hline HPLC & High Performance Liquid Chromatography \\
\hline Ig & Immunoglobulin \\
\hline $\mathrm{kDa}$ & kilo Dalton, 1000 Dalton \\
\hline MASCOT & a proprietary software tool for analyzing mass spectrometry data \\
\hline MS & Mass Spectrometry \\
\hline NBT & NitroBlue Tetrazolium \\
\hline NCBI & National Center for Bio Informatics \\
\hline
\end{tabular}




$\begin{array}{ll}\text { OCT } & \text { Optimum Cutting Temperature } \\ \text { PAGE } & \text { polyacrylamide gel electrophoresis } \\ \text { PAS } & \text { Periodic Acid Schiff's (Reagent) } \\ \text { ppt } & \text { parts per thousand } \\ \text { QTOF } & \text { Quadrupole Time-Of-Flight } \\ \text { RNA } & \text { ribonucleic acid } \\ \text { RP-HPLC } & \text { Reverse-Phase HPLC } \\ \text { SDS } & \text { sodium dodecylsulfate } \\ \text { SEM } & \underline{\text { scanning electron microscope }} \\ \text { TEM } & \text { transmission electron microscope } \\ \text { TEMED } & \text { N,N,N',N'-Tetraethylmethylene ethylenediamine } \\ \text { TFA } & \text { TriFluoro Acetic acid } \\ \text { uHPLC } & \text { Micro-bore HPLC }\end{array}$




\section{Chapter I}

\section{Introduction}

All metazoan animals, including invertebrates, are capable of protecting the integrity of their bodies. The means by which this is achieved may be non-specific (innate), or specific (adaptive). Invertebrates were long thought to have general and nonspecific defense mechanisms, such as phagocytosis and encapsulation (Metchnikoff, 1892). Specific immuno-competence leading to selectively inducible responses, with a memory component, is still considered to be restricted to vertebrates by some (Klein, 1989). However Hildemann et al. (1977) demonstrated that hard corals (cnidaria, anthozoa, hexacorallia) are capable of recognizing and defending against non-self in allograft reactions. Further evidence for the existence of defensive non-self recognition systems with some degree of specificity has been found in many invertebrate phyla (Hildeman, 1984). Highly specific immuno-recognition systems including allogeneic incompatibilities have been found in the most "primitive" metazoans, porifera (e.g. Buscema and van de Vyver, 1984) and cnidaria (e.g. Hauenschild, 1954,1956; Salter-Cid and Bigger, 1991; Cadavid, et al., 2004), and in the "higher" invertebrates, annelids, echinoderms, and tunicates (e.g. Sabbadin, 1988, De Tomaso and Weissman, 1998). Views on what can be considered an immune system vary widely (Lackie, 1980; Klein, 1989; Coombe, et al., 1984) generally trying to define invertebrate defenses in vertebrate terms (Ratcliff, 1985). Rinkevich (2012) argues passionately against this approach (of searching for mammalian cells and proteins) in invertebrates, he suggests instead that a functional approach would serve better. 
Body defenses in cnidarians may be specific or non-specific, and involve cellular and/or humoral (chemical factors such as agglutinins, opsonins, and antimicrobials) response components (Phillips, 1963; Bigger and Hildemann, 1982). As a first line of defense, surface mucus can serve as a physico-chemical barrier, entrapping and possibly killing potential pathogens (Ratcliff, 1985). Phillips (1963) demonstrated that the mucous secretions on the surfaces of sea anemones entrapped carbon particles, these particles were subsequently cleared from the surface, and the mucous secretions provided an acidic barrier against bacteria. Additionally, mucous has been implicated in the abrogation of aggression (Bigger, 1976).

Naturally occurring antimicrobial compounds are found in the tissues of hard corals (hexacorallia, scleratinia) and soft corals (octocorallia). These antimicrobial compounds from gorgonians are particularly potent antibiotics (Bigger and Hildemann, 1982) and first reported in 1958 (Burkholder and Burkholder).

Like all metazoans, cnidaria have cells capable of phagocytosis (Metchnikoff, 1892; Olano and Bigger, 2000). Cnidarian responses to foreign materials were first examined by Metchnikoff (1892) when he inserted dye-soaked thorns into the tissues of jellyfish (scyphozoa) and observed the migration of phagocytes to the thorn. In Swiftia exserta, different cell types have been ascribed phagocytic capability depending on their activation state: in the coenenchyme (tissue between polyps) constitutively phagocytic cells are restricted (in type and location), while activation induces phagocytic activity in multiple cell types within the coenenchyme (Olano and Bigger, 2000). Tissue phagocytes in cnidaria are described as scavenger cells and to have functions in wound healing, regeneration, and defense (Young, 1974; da Silveira and van't Hof, 1977; Olano, 1993; 
Meszaros and Bigger, 1999). Although phagocytosis is an innate capability, there seems to be selectivity toward different targets i.e., there is a specificity to the response (Lackie, 1980). Nevertheless, these cells do not seem to acquire specificity for new targets (Bigger, 1984).

When the invading foreign material is too large to be internalized by phagocytosis (e.g. large numbers of micro-organisms or large metazoan parasites) it may be surrounded by amoeboid cells or become encapsulated with a non-cellular sheath. The encapsulation may consist of polymerized dihydroxyphenylalanine (DOPA) - melanin, or the axial skeleton material, gorgonin, in response to invading algal growth (Goldberg, et al., 1984).

Cnidaria exhibit cellular responses to injury, and regenerate rapidly (Meszaros and Bigger, 1999). In scyphozoans and anthozoans, infiltration and accumulation of granular amoebocytes occurs after a lesion, e.g., thermal injury in actiniarians is followed by immigration of granular amoebocytes that eliminate necrotic tissue and promote tissue repair (Patterson and Landolt, 1979). In contrast, wound healing in hydrozoans exhibits no infiltration or accumulation of granular amoebocytes. If inflammation is as Metchnikoff states (1892, pg. 189), “...to be regarded as a phagocytic reaction ... carried out by mobile phagocytes..." then only scyphozoans and anthozoans, possess an inflammatory response to injury. Accordingly, body defense reactions may also be expressed as inflammatory type reactions involving cellular infiltration and phagocytosis (Bigger and Hildemann, 1982; Metchnikoff, 1892).

Metchnikoff, in 1905, hypothesized that phagocytic cells play a major role in the defense against disease. Invertebrate immunocytes (often called hemocytes, 
coelomocytes, or leukocytes, depending on the source animal and function) for most classes and phyla have been identified (Ratcliff, 1985), but characterization and terminology is often confusing. Invertebrate leukocytes are frequently referred to as lymphocytes, granulocytes or macrophages using vertebrate terminology, further increasing the level of confusion.

When studying cell types in cnidaria one must keep in mind that a particular cell (type) may serve more than one function, either concurrently or in developmental succession (Bigger and Hildemann, 1982). Since these animals lack a circulatory system, the cells involved in defense reactions may have other functions as well (Ratcliff, 1985; Lackie, 1980). Currently, amoebocytes are the putative immunocytes in cnidaria (of all classes). Several authors (reviewed in Bigger and Hildemann, 1982; Olano and Bigger, 2000) have implied that cnidarian amoebocytes are phagocytic and motile, and have implicated this cell type in a variety of functions. Amoebocytes appear to include a stem cell population and its various ontogenetic products (Bigger and Hildemann, 1982). They may function as effector cells maintaining the integrity of the body and have a role in wound healing (Young, 1974; da Sileria and van’t Hof, 1977). Other functions that have also been ascribed are mesogleal fiber secretion (Chapman, 1974), and development into scleroblasts and nematocytes (Buisson, 1970).

Prior to the present study little information on the nature of effector cells involved in cnidarian immune reactions existed. Patterson and Landholt (1979) and Young (1974) described wound healing in sea anemones, while da Silveira and van't Hof (1977), Olano (1993), Meszaros and Bigger (1999) showed the histology of wound healing in a few gorgonians. In addition, Olano (1993) documented the histological changes during 
grafting reactions in Swiftia exserta. However none of these authors describe the normal state of their model animal in detail by histology or by electron microscopy. In fact there are only seven in-depth histological studies of octocoral/gorgonian species (Bayer, 1956; Bayer, 1974; Benke and Hündgen, 1984; Bourne, 1895; Chester, 1913; Hickson, 1895; and Nutting, 1889) - none include Swiftia exserta, the animal model used here. Swiftia exserta has been used extensively in the Bigger lab to study a number of immunological reactions that include wound healing (Meszaros and Bigger, 1999), identification of activated phagocytic cells in paraffin sections (Olano, 1993; Olano and Bigger, 2000), and the cloning of the complement component C3-like cDNA (Dishaw, et al., 2005). No in depth electron microscopy study of an octocoral has been published (my chapter on the coenenchyme has been submitted), yet this area of the animal is of utmost interest for immune reactions. Fautin and Mariscal consolidated electron micrographs of assorted anthozoa into a chapter of the series "Microscopical Anatomy of Invertebrates" in 1991, but the diversity of animals in the class does not readily permit such over-generalization of grouping all anthozoa together. In chapter 2, I describe the histology and microanatomy of Swiftia exserta using light microscopy, scanning and transmission electron microscopy.

Enzyme-histochemistry has been used to identify hemocytes (and coelomocytes) capable of phagocytosis (and other immune reactions) in invertebrates and vertebrates. Chapter 3 details these studies on cryo-sections of Swiftia exserta to identify the constitutive phagocytic immunocytes in this model animal lacking a circulatory system (and thus true hemocytes). 
To study the evolution of antimicrobial peptides, important effector molecules of innate immunity, I have partially characterized Swiftin from acidified aqueous extracts of Swiftia exserta tissues (from the whole animal). Swiftin, a new molecule that I have named, is one of (at least) two proteins that show broad-spectrum antibacterial activity and is capable of killing both gram-positive and gram-negative bacteria. I show the partial purification, partial characterization, and screening for antibacterial activity of swiftin in chapter 4.

The purpose of my project was to study cellular effectors of cnidarian immunity using Swiftia exserta. This was accomplished by demonstrating: the morphology and ultrastructure of the animal, the presence of several enzymes characteristic of vertebrate phagocytic leukocytes in distinct cell types of Swiftia exserta to suggest which of these cell types is phagocytic, and the partial characterization of proteins with antibacterial activity. Since these investigations are an exploratory attempt to elucidate the immune reactions in a new model animal by methods novel to the phylum I remind the reader that the work is, by necessity, qualitative rather then quantitative due to the nature of the work. In fact, the beginnings of every field of endeavor must be descriptive in order to establish a baseline from which further lines of inquiry will originate - the questions of: what does the animal look like (inside and out); what cell types are present; which proteins can be found; and are any cells capable of phagocytosis are fundamental. These questions must be asked, and answered, before any further intelligently-designed questions can be phrased (summarized Sparks, 1993). 


\section{REFERENCES}

Bayer, F.M., 1956. The microanatomy of five holaxonian corals. M.S. Thesis. George Washington Univ.

Bayer F.M., 1974. Studies on the anatomy and histology of Plexaura homomalla in Florida. In: Prostaglandins from Plexaura homomalla: Ecology, utilization and conservation of a major medical marine resource. A Symposium. Univ Miami Press, Coral Gables, FL, pp. 62-100.

Benke, H. Hündgen, M., 1984. Mophologie und Struktur der Koralle Cornularia cornucopiae (Anthozoa, Octocorallia). Helgoländer Meeresunters. 38, 149-170.

Bigger, C.H., 1976. The acrorhagial response in Anthopleura krebsi: intraspecific and interspecific recognition. P 127-136 in Coelenterate Ecology and Behaviour, G.O. Mackie ed. Plenum Press, New York.

Bigger, C.H., 1984. Immunorecognition among invertebrates. Dev. Comp. Immunol. 3, 29-34.

Bigger, C.H., Hildemann, W.H., 1982. Cellular defense systems of the coelenterata. In: Cohen, N., Sigel, M., (Ed.) The Reticuloendothelial System. Plenum Press, New York, pp. 59-87.

Bourne, G.C., 1895. On the structure and affinities of Heliopora coerulea (Pallas), with some observations on the structure of Xenia and Heteroxenia. Proc. R. Soc. Lond. B 186, 455-483.

Buisson, B., 1970. Les supports morphologiques de l'integration dans la colonie de Veretillum cynamorium Pall. (Cnidaria, Pennatularia). Zeithschr. Morphol. Tiere 68, 136.

Burkholder, P.R., Burkholder, L.M., 1958. Antimicrobial activity of horny corals. Science 127(3307):1174-1175. 
Buscema, M., van de Vyver, G., 1984. Allogeneic recognition in sponges: Development, structure, and nature of the nonmerging front in Ephydatia fluviatilis. J. Morph. 181, 297303.

Cadavid, L.F., Powell, A.E., Nicotra, M.L., Moreno, M., Buss, L.W., 2004. An invertebrate histocompatibility locus. Genetics. 167, 357-365.

Chapman, D.M., 1974. Cnidarian Histology. In: Muscatine, L., Lenhoff, H.M. (Ed.), Coelenterate Biology. Reviews and new perspectives. Academic Press, New York, San Francisco, London, pp. 2-92.

Chester, W.M., 1913. The structure of the gorgonian coral Pseudoplexaura crassa Wright and Studer. Proc. Amer. Acad. Arts Sciences 48, 737-774.

Coombe, D.R., Ey, P.L., Jenkin, C.R., 1984. Self/non-self recognition in invertebrates. Qtr. Rev. Biol. 59: 231-250.

De Tomaso, A.W., Weissman, I.L., 1998. Mapping the genome of a model protochordate. I. A low resolution genetic map encompassing the fusion/histocompatibility $(\mathrm{Fu} / \mathrm{HC})$ locus of Botryllus schlosseri. Genetics 149, 277-287.

Dishaw, L.J., Smith, S.L., and C.H. Bigger. 2005. Characterization of a C3-like cDNA in a coral: phylogenetic implications. Immunogenetics. 57:535-548.

Fautin, D.G., Mariscal, R.N., 1991. Cnidaria: Anthozoa. In: Harrison, F.W., Westfall, J.A. (Ed.) Microscopic Anatomy of Invertebrates, Vol. 2. Placozoa, Porifera, Cnidaria, and Ctenophora. Wiley-Liss, New York, pp. 267-358.

Goldberg, W.M., Makemson, J.C., Colley, S.B., 1984. Entocladia endozoica sp nov, a pathogenic chlorophyte - Structure, Life History, Physiology, and Effect on its Coral Host. Biol. Bull. 166, 368-383.

Hauenschild, C., 1954. Genetische und Entwicklungsphysiologische Untersuchungen über Intersexualität und Gewebeverträglichkeit bei Hydractinia echinata Flemm. (Hyrdoz. Bougainvill.). Roux Arch Entwicklungsmch. 147, 1-41. 
Hauenschild, C., 1956. Über die Vererbung einer Gewebeverträglichkeits-Eigenschaft bei dom Hydroipolypen Hydractinia echinata. Zeitschr. Naturforsch. B. Chem. Biochem, Biophys. Bio. 11, 132-138.

Hickson, S.J., 1895. The anatomy of Alcyonium digitatum. Quart. J. Micr. Sci. NS. 37, 343-388, pl 36-39.

Hildemann, W.H., Raison, R.L., Cheung, G., Hull, C.J., Akaka, L., Okamoto, J., 1977. Immunological specificity and memory in a scleractinian coral. Nature 270, 219-223.

Hildemann, WH., 1984. A question of memory. Devel. Comp. Immunol. 8,747-756.

Klein, J., 1989. Are invertebrates capable of anticipatory immune responses? Scand. J. Immunol. 29, 499-505.

Lackie, A.M., 1980. Invertebrate Immunity. Parasitology. 80, 393-412.

Meszaros, A., Bigger, C.H., 1999 Qualitative and quantitative study of wound healing processes in the coelenterate, Plexaurella fusifera: spatial, temporal, and environmental (light attenuation) influences. J. Invert. Path. 73: 321-331.

Metchnikoff, E., 1892. Lecons sur la Pathologie comparee de l'Inflammation. Masson, Paris; reissued in English (1968) Lectures on the Comparative Pathology of Inflammation. Dover Publication Inc, New York.

Metchnikoff, E., 1905. Immunity in infectious diseases. Cambridge University Press, Cambridge.

Nutting, C.C., 1889. Contribution to the anatomy of gorgonidae. Univ. Iowa Lab. Nat. Hist. Bull. 1:97-160.

Olano, C.T., 1993 Cellular aspects of alloimmunity and other responses in the gorgonian Swiftia exserta. Thesis (M.S.) Florida International University. 
Olano, C.T., Bigger, C.H., 2000. Phagocytic activities of the gorgonian coral Swiftia exserta. J. Invert. Path. 76: 176-184.

Patterson, M.J., Landolt, M.L., 1979. Cellular reaction to injury in the anthozoan Anthopleura elegantissima. J. Invert. Path.. 33, 189-196.

Phillips, J.H., 1963. Immune mechanisms in phylum Coelenterata. P 425-431 in: "The lower Metazoa" E.C. Doughterly, Z.N. Brown, E.D. Hanso, W.D. Hartman eds. University of California Press, Berkeley.

Ratcliffe, N.A., 1985. Invertebrate immunity - a primer for the non-specialist. Immun. Lett. 10, 253-270.

Rinkevich, B., 2012. Neglected biological features in cnidarians self-nonself recognition. Adv. Exp. Med. Biol. 738, 46-59.

Sabbadin, A., Astori, C., 1988. Chimeras and histocompatibility in the colonial ascidian Botryllus schlosseri. Devel Comp. Immunol. 12, 737-747.

Salter-Cid, L., Bigger, C.H., 1991. Alloimmunity in the gorgonian coral Swiftia exserta. Biol. Bull. 181, 127-134.

da Silveira, F.L., van't Hof, T., 1977. Regeneration in the gorgonian Plezaura flexuosa (Cnidaria, Octocorallia). Bijdragen tot de Dierkunde 47, 98-108.

Sparks, A.K. 1993. Invertebrate Diseases - An overview. P 245-254 in: "Pathobiology of Marine and Estuary Organisms," J.A. Couch, J.W. Fournie, eds. CRC Press. Boca Raton.

Young J.A., 1974. The nature of tissue regeneration after wounding in the sea anemone Calliactis parasitica (Couch). J. Mar. Biol. Assoc. UK., 54: 599-617. 


\title{
Chapter II
}

Histology and Ultrastructure of the Octocoral Swiftia exserta, A Model Organism for Innate Immunity/Graft Rejection.

Part I: the Coenenchyme - ectoderm, cells of the mesoglea, solenia gastroderm, and axial skeleton.

\begin{abstract}
The octocoral Swiftia exserta has been utilized extensively to study innate immune reactions in cnidaria such as wound healing, auto- and allo-graft reactions, and some classical "foreign body" phagocytosis experiments. All of these reactions occur in the coenenchyme of the animal, the colonial tissue surrounding the axial skeleton in which the polyps are embedded, and do not rely on nematocysts or directly involve the polyps.

To better understand some of the cellular reactions occurring in the coenenchyme the present study employed several cytochemical methods (Periodic-acid Schiff's reaction, Mallory's aniline blue collagen stain, and Gomori's trichrome) and correlated the observed structures with electron microscopy (both scanning and transmission) and light microscopy. Eight types of cells were apparent in the coenenchyme of Swiftia exserta, exclusive of gastrodermal tissue: 1) ectoderm epithelia, 2) oblong granular cells, 3) granular gland cells, 4) granular amoebocytes, 5) small mesoglea cells, 6) axial epithelia, 7) cnidocytes with macrobasic amastigopore nematocysts, and 8) cnidocytes with atrichous isorhiza nematocysts. Several novel organizational features are now
\end{abstract}


apparent from transmission electron micrographs: the ectoderm consists of a single layer of flat epithelia-like cells, the three cell types of the mesoglea extend from beneath the thin ectoderm throughout the mesogleal cell cords, the gastroderm of the solenia is the only tissue that resembles its counterpart in Hydra ssp., and two nematocyst types have been found.

A new interpretation of the foundations of cellular immunity in octocorals is now possible with the newly described histology and ultrastructure presented here.

\section{INTRODUCTION}

Swiftia exserta (Cnidaria, Anthozoa, Octocorallia, Alcyonacea, Holaxonia, Plexauridae) forms branching colonies (fig. 1A, B) composed of a supporting hollow axis of gorgonin, an iodinated fibrous protein (Szmant-Froehlich, 1974), surrounded by coenenchyme (colonial tissue) with embedded polyps. The species was initially described in Ellis \& Solander (1786) as Gorgonia exserta and animals in this order are commonly referred to as gorgonians. The genus was renamed Swiftia and Swiftia exserta designated the type species of genus Swiftia by Duchassaing and Michelotti in 1860.

Initial descriptions of alcyonarians ([gorgonidae] v. Koch, 1887) described triploblastic tissue organization. Currently, cnidarians are considered diploblastic, however with an outer ectoderm separated from the endo/gastroderm by a fibrous or gelatinous mesoglea layer. The thickness and cellular infiltration of the mesoglea varies by class among the cnidaria (Chapman, 1974): Hydra ssp. representing the hydrazoa have a very thin acellular mesoglea (Davis and Haynes, 1968) while both the cubozoa and scyphozoa in the medusa stage have thick, mostly acellular, mesoglea (Chapman, 1953). 
The anthozoan mesoglea is generally laced with individual cells (Tucker, Shibata and Blankenship, 2011) or cords of cells (Bayer, 1974; da Silva and van't Hof, 1977).

The polyps of octocorals are composed of eight pinnate (feathered) tentacles that unite at the oral disk (illustrated nicely in v. Koch, 1887; Hickson, 1895). Tentacles are histologically simple structures composed of an outer ectoderm cell layer, a thin mesoglea, and an inner endo/gastroderm layer (Nutting, 1889; Chester, 1913). 'Aboral' and 'oral' are used to differentiate the surfaces of the hollow tentacles (Fautin and Mariscal, 1991), with the oral ectoderm facing the oral disk and the inside of the tentacles generally composed of a layer of endo/gastroderm. The tentacles unite at the oral disk which leads into the coelenteron, yet the tentacles retain their separation internally by sheets of fibrous mesoglea. These eight dividers in the gastric cavity, termed mesenteries, are lined with musculo-epithelial cells, muscle bundles, and gastroderm (v. Koch, 1887; Hickson, 1895). The oral ectoderm extends into the upper gastric cavity in an area described variously as a pharynx or stomodeum. At the elongated ends of the polyp mouth are two heavily ciliated grooves, the siphonoglyphs (Hickson, 1883). Gonads, when present, are located along the mesenteries (Bayer, Grasshoff, \& Versefeldt, 1983).

In gorgonians the gastrovascular cavities of the individual polyps are interconnected by ciliated tubes (solenia) (Murdock, 1978) to larger, axis-parallel, stem canals (Bayer, 1956, 1961; Bayer, Grasshoff, \& Versefeldt, 1983) (fig. 2). Both solenia and stem canals are lined with endo/gastroderm (Bayer, 1956, 1961, 1974), and both are embedded in mesoglea. Solenia and stem canals have been shown to circulate nutrients throughout the coenenchyme and between polyps (Murdock, 1978; Gladfelter, 1983). Similarly embedded in the mesoglea are the sclerites or spicules that are characteristic for 
a given species and are thus used to delineate genus and species (often regardless of outward morphological differences or similarities) (Nutting, 1889; Bayer, 1974; Bayer, Grasshoff, \& Versefeldt, 1983; Goldberg 2001).

Covering the mesoglea is a cellular layer of ectoderm. In various cnidarian classes the ectoderm ranges from a single columnar layer (Hickson, 1895; Chester, 1913; Bayer, 1974) to indeterminate layers and cell shapes (Kawaguti, 1966). In von Koch’s 1887 description, ectoderm consists of: 1) polygonal, mostly flat to cylindrical cells with fine hairs ["wimpern"] covering their exterior surface. These cells overlay a mix of other ectoderm cell types, including 2) epithelio-muscular cells; 3) round, undifferentiated cells; 4) thin sensory cells with thicker projections upwards and thinner ones downward to 5) interconnected ganglion cells; and interspersed between the taller, upper, cells are 6) nematocytes of various sizes and shapes.

A small handful of published reports describe the histology of zooxanthellate gorgonians: Pseudoplexaura crassa Studer \& Wright [now Pseudaoplexaura porosa] (Chester, 1913), Plexaura homomalla (Bayer, 1974), and Plexaura flexuosa (da Silveira and van't Hof, 1977). The polyps of Dendrophyllia cribrosa (Kawaguti and Yokoyama, 1966) and Heteroxenia elisabethae (Kawaguti, 1969) have been described by TEM, to complete the short list of published histological and ultrastructure studies of gorgonians. In the reports mentioned above the cell types are described based on morphology, while function is inferred from structural similarity to known (mammalian) cell types. Classifying (cnidarian) cell types solely on morphology has limitations however, as functional roles cannot be assigned with certainty. Only a few reports describe the presence of specific enzymes within Hydra ssp. tissues (Lentz and Barrnett, 1961; Hand, 
1976) and in the mesenteries of the anthozoan Pachycerianthus fimbriatus (Tiffon and Hugon, 1977) in attempts to assign some function to cell types. However, any described cell type may serve several functions, either concurrently or in developmental succession (Bigger and Hildemann, 1982).

In the current study on Swiftia exserta we will illustrate for the first time the structure, basic cell types, and tissue organization of an azooxanthellate gorgonian, Swiftia exserta. The present report is part of an organized study of the cellular/immunological defense responses of a model organism from a phylum that diverged early in metazoan evolution, prior to the deuterostome-protostome split. To understand the cellular responses, such as tissue fusion or rejection, response to injury, and foreign body responses, it is first necessary to understand the animal's normal anatomical and cellular condition and structure.

\section{MATERIALS \& METHODS}

\section{Maintenance of Animals}

Colonies of the gorgonian Swiftia exserta were obtained from Dr. Henry Feddern, who collected them off the coast of Southeast Florida by SCUBA at depths of approximately 20-30 meters. Both whole colonies and experimental tissues were maintained in 30, or 550 gallon closed system aquaria with artificial sea salts (eg. Instant Ocean, Red Sea, or Reef Crystals) adjusted to 37 ppt salinity. Water quality was minimally conditioned via sub-gravel filters, activated charcoal filters, and protein skimmers. Care was taken to avoid contact between the colonies. The animals were fed 
1-2 day old Artemia nauplii (San Francisco Bay Brand, Newark, CA) three times a week. Water temperatures ranged from $19-23^{\circ} \mathrm{C}$.

\section{Light Microscopy}

Tissues were fixed in Helley's fixative (Clark, 1981), rinsed in 0.22 micron filtered sea water (FSW), decalcified in $2 \%$ ascorbic acid, dehydrated in a graded series of ethanol and embedded in Paraplast (Fisher Scientific, Waltham, MA) at $56^{\circ} \mathrm{C}$.

Sectioning was performed on a Reichert-Jung 2800 Frigocut $\mathrm{N}$ cryostat at $-20^{\circ} \mathrm{C}$, using a metal knife to obtain 5-6 micron sections. Tissues were stained with: Harris' Hematoxlylin and Eosin Y (H\&E), H\&E/Orange G; Periodic Acid Schiff’s reagent/Alcian Blue; Toluidine Blue; Mallory’s Aniline Blue Collagen stain (without iodine); and Gomori’s Trichrome following Clark (1981).

\section{Cell counts}

Cell counts were performed by randomly selecting a 200 micron diameter field of view and counting only those cells whose nuclei were visible.

\section{Electron Microscopy}

\section{Transmission Electron Microscopy}

Short branches $(4-6 \mathrm{~cm})$ were cut from the ten different larger colonies, transported to the lab in FSW and the polyps were given time to expand. Expanded polyps were anesthetized with magnesium chloride, fixatives ( $4 \% \mathrm{v} / \mathrm{v}$ paraformaldehyde and $2 \% \mathrm{v} / \mathrm{v}$ glutaraldehyde, both from Ted Pella, Redding, CA) were added drop-wise away from the tissue, and the tissue was fixed overnight at room temperature. Tissue was processed essentially as in Menzel, et al., 2001: Fixed branchlets were washed several 
times with FSW before polyps, individual tentacles, or coenenchyme pieces were dissected out and post-fixed in $1 \%$ osmium tetroxide for four hours at room temperature. Following dehydration in a graded ethanol series and propylene oxide (Electron Microscopy Sciences, Hatfield, PA) the tissue pieces were slowly infiltrated with EmBed812 (Electron Microscopy Sciences) over two days, oriented in flat embedding molds (Ted Pella, Redding, CA) and polymerized at $60^{\circ} \mathrm{C}$ for 48 hours. Trimmed blocks were sectioned with a diamond knife (Dupont) on a Sorvall Porter-Blum MT-2B. Sections were double stained with aqueous uranyl acetate for 15 minutes at $60^{\circ} \mathrm{C}$ and Reynold's lead citrate (Reynolds, 1963) for 2.5 minutes at room temperature, and viewed with a JEM 1010 Transmission Electron Microscope (JEOL, Peabody, MA).

Sections were cut parallel to the axial skeleton or perpendicular to the axial skeleton from different blocks. Two to three sections were collected on each grid, three grids worth of sections were collected per block sectioned, and three blocks per orientation were sectioned, stained, and viewed.

\section{Scanning Electron Microscopy}

Branchlets were collected, relaxed, anesthetized, fixed, washed, and post-fixed as above. Several short $(1-2 \mathrm{~cm})$ branch pieces were dehydrated through a graded ethanol series, individually mounted on SEM stubs with sugar-free chewing gum (Walter Goldberg, pers. comm.), critically point dried with a Samdri-PVT-3D (Tousimis, Rockville, MD), coated with approximately $30 \mathrm{~nm}$ gold with an SPI-MODULE sputter coater (Structure Probe, Inc, West Chester, PA), and viewed on a JSM 5910LV Scanning Electron Microscope (JEOL, Peabody, MA). 


\section{Coenenchyme Tissue Morphology}

\section{RESULTS}

The typical anthozoan three layered body plan (ectoderm, mesoglea, and endoderm) is present in Swiftia exserta (fig. 3A). These tissues surround a hollow axial skeleton as in other members of the holaxonia (fig. 3B). The outer layer of the coenenchyme rind is composed of single layer of squamous epithelial cells covered with microvilli (fig. 3C, 3D) overlaying oval, heavily granulated cells (fig. 3E, fig. 3F). Spicules, or sclerites, are embedded in a matrix of mesoglea (fig. 4B, fig. 4E) and can, at times, extend to just below the surface such that only the flat ectoderm epithelia covers them.

Underlying the ectoderm is the thick, richly cellular mesoglea, permeated with solenia (fig. 4A) and studded with spicules (fig. 4B, fig. 4E). Cells in the mesoglea are loosely arranged into ubiquitous cell cords, or surround the spicules with thin cellular extensions (fig. 4D). The matrix of the mesoglea conforms to published reports on cnidarian mesoglea in general (fig. 5A-D) (Davis and Haynes, 1968; Bouillon and Coppois, 1977), however 'granular amoebocytes' are absent from the mesoglea matrix, but not from the mesogleal cell cords.

The gastroderm of the solenia in Swiftia exserta coenenchyme and in the stem canals is shown by histology and in TEM overview in fig.s 6A and 6B-C. Several secretory cell types (fig. 6D) including a cell type that resembles the zymogen cells found in Hydra ssp. (fig. 6E), cells with phagocytic vesicles (fig. 6C, 6E-F), and flagellated collar cells (fig. 6G-H) are easily distinguished. 
Desmocytes, the attachment foci of the coenenchyme mesoglea, and thus tissue, are used throughout cnidaria to attach the mesoglea fibers to the axial skeleton (fig 7BD). The desmocytes of Swiftia exserta are arranged in groups called plaques, as seen in fig. 7A. Cross sections of the attachment foci (fig. 7B-D) are anchored into the axial skeleton with rounded ' $\mathrm{T}$ ' shaped extensions at the base of the wedge-shaped desmocyte structures and merge into mesogleal fibers at their opposing end. Compartments within the axial skeleton that define the group holaxonia, described in Pterogorgia bipinnata (fig112, Kükenthal, 1919), are clearly visible in Swiftia exserta (fig. 3A and B).

\section{Cell Types of the Coenenchyme, excluding Solenia Gastroderm}

The gastrodermal cells of Swiftia exserta's solenia resemble anthozoan gastroderm cells described in Fautin and Mariscal (1991) and are similar to gastroderm in Hydra ssp. A detailed description of the observed cell types in the ectoderm and the mesoglea follows:

\section{Squamous epithelial ectoderm cells}

These cells of the ectoderm are thin, flattened and cover the coenenchyme of the colony. Outer surfaces of the epithelial cells are covered with microvilli (fig 3C-D), while the cytoplasm is finely granular and contains a few large mucus granules and small granules. The nucleus is flattened, ovoid, and finely granular with a prominent nucleolus. The outer surface of the epithelial cells stains strongly with Alcian blue, indicating a large amount of acidic mucopolysaccharide, mostly strongly sulphated acidic mucopolysaccharides (as demonstrated by Alcian blue $\mathrm{pH} 0.2$ staining) (Parker and Diboll, 1966). Intense staining of the ectoderm-environment surface is seen with buffered 
osmium tetroxide indicating that this outer surface is covered with a thin layer of polyunsatured lipids (fig. 3f) as determined by imidazole-buffered osmium tetroxide fixation (Angermüller and Fahimi, 1982).

\section{Oblong Granular Cells}

These cells, found just underneath the flat epithelial layer (fig. 3E-F, and fig. 4CD) are generally oblong or oval in shape (sometimes more elongate), and constitute approximately $63 \%$ of the cells in the cell cords (3429 cells were counted from sections on four grids from three different individuals, 2160 are classified as oblong granular cells). Their shape is mainly determined by contact with adjacent cells. Average dimensions are $8 \times 6 \mu \mathrm{m}$ with a small $(2 \mu \mathrm{m})$, round and dense nucleus. The cytoplasm is completely filled with highly refractile, small $(0.5-1 \mu \mathrm{m})$ uniformly sized granules (twenty granules were measured in cells from three individuals). Although in some preparations these cells stain weakly with hematoxylin or eosin, they are generally neutrophilic, staining a light yellow-brown color. By TEM these granules are intensely osmiophilic and completely fill the cytoplasm (fig. 4D). There are occasional very electron-lucent granules, that likely contained unsatured lipids now washed out by processing, interspersed between the many intensely osmiophilic granules. These cells are also located throughout the cell cords in the coenenchyme and are the most abundant cell type in the coenenchyme, representing approximately $63 \%$ of the coenenchymal cells. 


\section{Granular Amoebocytes}

Approximately $36 \%$ of the cells in cell cords are granular amoebocytes (3429 cells were counted from sections on four grids from three different individuals, 1234 are classified as granular amoebocytes). Granular amoebocytes do not represent a homogeneous population of cells (fig. 3F fig. 4C-D, fig.5D), but include various subpopulations and/or developmental stages (Bigger and Hildemann, 1982). Consequently granule size and content varies greatly in these cells. Often elongate, with sizes ranging from lengths of 6-20 $\mu \mathrm{m}$ and widths of 4-10 $\mu \mathrm{m}$ these cells are all amoeboid in shape with nuclei irregularly round or ovoid, 2-3 $\mu \mathrm{m}$ in diameter (see plates 3-5). Hematoxylin and Eosin staining usually stains the nuclei basophilic (on occasion moderately acidophilic) and the cytoplasm weakly basophilic (data not shown). Small to large granular amoebocytes have an assortment of granules of different sizes $(0.5-2 \mu \mathrm{m})$, staining properties (acidophilic, basophilic, and neutrophilic), and relative quantities. Distinct sub-populations of granular amoebocytes are difficult to classify by microscopy alone.

\section{Morula-like Cells}

These globular cells have average dimensions of 9x7 $\mu \mathrm{m}$ with a very small (2 $\mu \mathrm{m})$, dense nucleus. The cytoplasm is completely filled with spherical, uniform-sized granules (1-2 $\mu \mathrm{m})$ (fig. 5D). With H\&E staining, the nucleus is strongly basophilic and the granules are strongly acidophilic. The granules also demonstrated an acidophilic nature with Chromotrope 2R (Gomori's stain) and stain weakly with PAS. These cells 
were not very numerous representing only approximately $0.5 \%$ of the cells in cell cords and are scattered throughout the coenenchyme (3429 cells were counted from sections on four grids from three different individuals, 17 are classified as morula-like cells).

\section{Sclerocytes}

The sclerocytes (responsible for secreting spicules) are located either directly on the spicules (fig. 4E) or in the mesoglea surrounding the sclerite cavity (fig. 4B, fig. 5C). Occasionally, more than one sclerocyte is found in association with a spicule. These cells are elongate or very thin and flattened, measuring up to $35 \mu \mathrm{m}$ in length and 0.5 to $2 \mu \mathrm{m}$ in thickness. The finely granular, ovoid nucleus is equally flattened, measuring up to 6 $\mu \mathrm{m}$ at its largest diameter and $1 \mu \mathrm{m}$ in thickness. The cytoplasm contains many small granules and small vacuoles measuring between 0.5 and $2 \mu \mathrm{m}$. With H\&E staining, the cytoplasm is very weakly basophilic. PAS positive granules are most often found in the sclerocytes directly on the spicules.

\section{Mesogleal cells}

The mesogleal cells were embedded within the gelatinous mesoglea and are relatively uncommon. Since mesogleal cells are not found in the cell cords and only rarely in the mesoglea they constitute a very minor fraction of the animals entire cell population - only 28 were observed by either light microscopy or by TEM. These cells are very small amoeboid, with one or more elongated and branched processes extending into the mesoglea. The cell body is usually less than $9 \mu \mathrm{m}$ in length and very thin (as thin as $1.5 \mu \mathrm{m})$. The nucleus occupies a large portion of the cell body, and is ovoid, finely 
granular, and 2-5 $\mu \mathrm{m}$ in diameter. Often the cytoplasm contains granules that stain intensely with both osmium and aniline blue (fig. 5A-B).

\section{Axial Epithelial Cells and Desmocytes}

The axial skeleton possesses striations atop the skeletal material, perpendicular to the surface of the axis. The striated zones (desmocyte plaques) have an irregularly oval outline and are areas of axis formation (Szmant-Froehlich, 1974; Kingsley and Watabe, 1982). Each desmocyte plaque was individually surrounded by one axial epithelial cell that curved around the group of striations, while other epithelial cells of irregular shape occupied the spaces between the curved cells. The individual desmocytes are delimited by tight junctions that bind them to neighboring desmocytes (fig $7 \mathrm{~b}$ and $\mathrm{d}$ ) within a desmocyte plaque. Unfortunately, no desmocyte developmental stages were observed. Descriptions of the desmocytes of Leptogorgia virgulata (fig 2, Kingsley and Watabe, 1982) are very similar showing cells filled with secretory vesicles surrounding the striated desmocytes. The nuclei are finely granular, approximately $3 \mu \mathrm{m}$ in diameter and, along with the cytoplasm, basophilic with H\&E staining. The cytoplasm contains many small granules and vacuoles (fig. 7B). While the structure of the desmocyte attachments is very similar across octocorals they do not match Chapman's report on desmocytes in the scyphozoan Aurelia aurita or the hydrozoan Clava multicornis (Chapman, 1969).

\section{Nematocytes}

Swiftia exserta contains two types of nematocysts in the coenenchyme: small basophilic nematocysts (Type I - atrichous isorhiza) (at lower left of fig. 3F) and large 
acidophilic nematocysts (Type II - macrobasic amastigophores). Nematocyst types were identified by characteristics published (Weil, 1934).

Type I nematocysts (atrichous isorhiza) are mainly found in the coenenchyme away from the anthostele and occasionally in groups of up to three. These larger (though still relatively small) nematocysts have kidney shaped capsules 6-8 $\mu \mathrm{m}$ in length and 4-5 $\mu \mathrm{m}$ in width. The thread stains green with Gomori's Trichrome. These nematocysts also do not stain distinctively with PAS or Alcian blue. The cigar-shaped Type II nematocysts, approximately $8-10 \mu \mathrm{m}$ in length and 2-2.5 $\mu \mathrm{m}$ in width are found primarily in the polyp and the anthostele.

\section{DISCUSSION}

While the gross morphology of Swiftia exserta conformed to reports on other holaxonian gorgonians (Chester, 1913; Bayer, 1974), many differences were observed at the cellular level.

Histological descriptions of gorgonian tissues and cell types are limited (see below). The most appropriate descriptions are those of Pseudoplaxaura crassa (now known as Pseudoplexaura porosa) by Chester (1913), of Plexaura homomalla by Bayer (1974), and of Plexaura flexuosa in a study on regeneration by da Silveira and van't Hof (1977). Even the ultrastructural studies by Kawaguti $(1966,1969)$ only discuss polyps, while the reports on Leptogorgia virgulata (Kingsley and Watabe, 1982a, 1982b, 1983) focus on the axial skeleton or spicule formation and composition. However, none of these studies examined the coenenchyme, nor was electron microscopy utilized to study the coenenchyme organization. 
The coenenchymal epithelial cells of Swifttia exserta are unlike those of most coelenterates in that they were not columnar (Bourne, 1895; Hickson, 1895); instead, they were thin and flattened forming a squamous epithelium over the entire colony. Some incidental views of squamous epithelia (from Leptogorgia virgulata) can be seen in Kingsley and Watabe (1982a, fig 9), Fautin and Mariscal (1991, fig. 3, 13-15), and Satterlie and Case (1978). Chester (1913), Bayer (1974), and da Silveira and van't Hof (1977) all describe columnar ectoderm epithelia.

Because of the similarity of the cells underlying the ectoderm epithelia with the cells in the mesogleal cell cords we do not consider these cells to be part of the ectoderm. Only the thin layer of flattened cells should be referred to as the ectoderm.

The axial epithelium of Swiftia exserta is not columnar and was found to form a thin layer covering the axis, more similar to (although somewhat thinner than) that of Plexaura homomalla (Bayer, 1974). Swiftia exserta's axial epithelium is unlike the axial epithelium of the sea whip Leptogorgia virgulata (Tidball, 1981,1982a, 1982b). Sections of the attachment foci (fig. 7B-D) parallel to the skeleton axis are most similar to those found in the octocorallians Leptogorgia virgulata (Tidball 1982a), Dendronephthya hemprichi (Barneah, Malik, and Benayahu, 2002), Cornularia cornucopia (Benke and Hündgen, 1984) and to desmocytes found in hexacorallia Stylophora psitillata (Muscatine, Tambutte, and Allemand, 1997).

The gastrodermal architecture conformed to that normally found in anthozoans shown in Fautin and Mariscal, 1991, but it appears to differ from other reported anthozoan gastroderm cell types and arrangement (Chester, 1913; Bayer, 1974). Morphologically, the solenia gastroderm resembles the endoderm of Hydra ssp., 
including zymogen cells (fig. 6E, H) (Haynes and Davis, 1969), several types of secretory cells (fig. 6B-D), and collar cells (fig. 6B, G-H) (Fautin and Mariscal, 1991). The many flagella present in the solenia are likely used for liquid and nutrient movement between polyps and from polyps to the cells in the coenenchyme (Murdock, 1978; Gladfelter, 1983).

The oblong granular cells of Swiftia exserta are pigmented and thus responsible for giving the colony its orange color (W. Goldberg pers. comm. for TEM evidence; Olano, 1993). Pigment distribution in Swiftia exserta is very different than in Leptogorgia virgulata, where pigments are found surrounding the sclerites (Adams, 1979). However, pigment cells similar to those of Swiftia exserta have been found in the ahermatypic soft coral Dendrophillia cribrosa (Kawaguti and Yokoyama, 1966); they contained $1 \mu \mathrm{m}$ granules that were composed at least partially of carotenoids. The absence of oblong granular cells in Plexaura homomalla and Pseudoplexaura crassa was not surprising because the color in these colonies is also attributable to their spicules (Bayer, 1961). Although the oblong granular cells described for Plexaura flexuosa closely resemble those of Swiftia exserta, in Plexuara flexuosa they are not responsible for the color of the colony (Bayer, 1961) for the color is found in the spicules.

Although Pseudoplexaura crassa lacked the oblong granular cells of Swiftia exserta, the cells of its coenenchyme appeared the most similar to that of Swiftia exserta. The Pseudoplexaura crassa cells that Chester (1913) identified as interstitial cells and granular interstitial cells appear to be the same as the granular amoebocytes of Swiftia exserta (see Bigger \& Hildemann, 1982 for a discussion of the interstitial cell/amoebocyte issue). The mesogleal cells of both species are likewise identical. 
Chester (1913) suggested that the interstitial cells, the interstitial cells with few granules, the interstitial cells with large granules and the mesogleal cells were a developmental series. The mesogleal cells of Swiftia exserta are amoebocytic as well, but are classified separately in this study because they are a distinctly different type of amoebocyte found isolated in the mesogleal fibers. Both the interstitial cells and the mesogleal cells described for Plexaura flexuosa are very different from those of Swiftia exserta. Swiftia exserta also lacked the frothy cells (cells of the coenenchymal cell cords) and the bloodcorpuscle-like cells described for Plexaura homomalla (Bayer, 1974).

The study of Goldberg and Benayahu (1987) with Pseudoplexaura flagellosa demonstrated both primary and secondary scleroblasts. The sclerocytes observed in the tissues of Swiftia exserta seem to be engaged in the extracellular calcification of spicules (secondary sclerocytes). Primary sclerocytes, cells with internal calcification vesicules, were not found. In Swiftia exserta, the spicules formed in the regenerating front after wounding are surrounded by several scleroblasts, suggesting a multicellular origin. Electron micrographs occasionally capture a nucleus, but rarely have cell boundaries been seen around sclerites/sclerite vacuoles (fig. 4C and fig. 5C) indicating a possible syncytial nature of spicule formation (Goldberg and Benayahu, 1987).

\section{ACKNOWLEDGMENTS}

I thank Tom Beasley and the Florida Center for Advanced Electron Microscopy (FCAEM), Florida International University for his assistance (and for training LPM) on the JEOL JSM 5910LV SEM. 


\section{REFERENCES}

Adams, R.O., 1979. Results of crossbreeding color varieties of the gorgonian, Leptogorgia virgulata (Cnidaria, Octocorallia). Amer. Zool. 19, 985.

Angermüller, S., Fahimi, D., 1982. Imidazole-buffered osmium tetroxide: and excellent stain for visualization of lipids in transmission electron microscopy. Histochem. J. 14, 823-835.

Barneah, O., Malik, Z., Benayahu, Y., 2002. Attachment to the substrate by soft coral fragments: desmocyte development, structure, and function. Invert. Bio. 121, 81-90.

Bayer, F.M., 1956. The microanatomy of five holaxonian corals. M.S. Thesis. George Washington Univ.

Bayer, F.M., 1961. The shallow-water octocorallia of the West Indian region. Studies on the Fauna of Curacao and other Caribbean Islands No. 12. M. Nijhoff, The Hague.

Bayer F.M., 1974. Studies on the anatomy and histology of Plexaura homomalla in Florida. In: Prostaglandins from Plexaura homomalla: Ecology, utilization and conservation of a major medical marine resource. A symposium. Univ. Miami Press, Coral Gables, FL, pp. 62-100.

Bayer, F.M., Grasshoff, M., Versefeldt, J., 1983. Illustrated tri-lingual glossary of morphological and anatomical terms applied to octocorallia. E.J. Brill, Leiden.

Benke, H. Hündgen, M., 1984. Mophologie und Struktur der Koralle Cornularia cornucopiae (Anthozoa, Octocorallia). Helgoländer Meeresunters. 38, 149-170.

Bigger, C.H., Hildemann, W.H., 1982. Cellular defense systems of the coelenterata. In: Cohen, N., Sigel, M., (Ed.) The Reticuloendothelial System. Plenum Press, New York, pp. 59-87.

Bourne, G.C., 1895. On the structure and affinities of Heliopora coerulea (Pallas), with some observations on the structure of Xenia and Heteroxenia. Proc. R. Soc. Lond. B 186, 455-483. 
Bouillon, J., Coppois, G., 1977. Étude Comparative de la Mésoglé des Cnidaires. Cahiers Biol. Mar. 18, 339-368.

Chapman, D.M., 1969. The nature of cnidaria desmocytes. Tiss. Cell 1:619-632.

Chapman, D.M., 1974. Cnidarian Histology. In: Muscatine, L., Lenhoff, H.M. (Ed.), Coelenterate Biology. Reviews and New Perspectives. Academic Press, New York, San Francisco, London, pp. 2-92.

Chapman, G., 1953. Studies of the mesoglea of the coelenterates. I. Histology and chemical properties. Qtrly. J. Micr. Sci. 94,155-176.

Chester, W.M., 1913. The structure of the gorgonian coral Pseudoplexaura crassa Wright and Studer. Proc. Amer. Acad. Arts Sciences 48, 737-774.

Clark, G., 1981. Staining procedures used by the Biological Stain Commission. Williams $\&$ Wilkins, Baltimore, MD.

Davis, L.E, Haynes, J.F., 1968. An ultrastructural examinatioin of the mesoglea of Hydra. Z. Zellforsch. Mikr. Anat. Histochem. 92,149-158.

Duchassaing, P., Michelotti, G., 1860. Memoire sur les Coralliaires des Antilles. Turin, De L'Imprimerie Royale.

Ellis J., Solander, D., 1786. The Natural history of many curious and uncommon zoophytes: Collected from various parts of the Globe. London, Benjamin White \& Son.

Fautin, D.G., Mariscal, R.N., 1991. Cnidaria: Anthozoa. In: Harrison, F.W., Westfall, J.A. (Ed.) Microscopic anatomy of invertebrates, Vol. 2. Placozoa, porifera, cnidaria, and ctenophora. Wiley-Liss, New York, pp. 267-358.

Gladfelter, E.H., 1983. Circulation of fluids in the gastrovascular system of the reef coral Acropora cervicornis. Biol. Bull. 165: 619-636. 
Goldberg, W.M., Benayahu, Y., 1987. Spicule formation in the gorgonian coral Pseudoplexaura flagellosa. 1. Demonstration of intracellular and extracellular growth and the effect of ruthenium red during decalcification. Bull. Mar. Sci. 40, 287-303.

Goldberg, W.M., 2001. The sclerites and geographical distribution of the gorgonian Swiftia exserta. Bull. Biol. Soc. Wash. 10, 100-109.

Hand, A.R., 1976. Ultrastructural localization of catalase and L-alpha-hydroxy acid oxidase in microperoxisomes of Hydra. J. Histochem. Cytochem. 24, 915-925.

Haynes, J.F., Davis, L.E., 1969. The Ultrastructure of the zymogen cells in Hydra viridis. Z. Zellforsch. 100, 316-324.

Hickson, S.J., 1883. On the ciliated groove (siphonoglyphe) in the stomodeum of the Alcyonarians. Proc. R. Soc. London 174:693-705.

Hickson, S.J., 1895. The Anatomy of Alcyonium digitatum. Quart. J. Micr. Sci. NS. 37, 343-388, pl 36-39.

Kawaguti, S., 1966. Electron microscopy on the fluorescent green of reef corals with a note on mucous cells. Biol. J. Okayama Univ. 12, 11-21.

Kawaguti, S., Yokoyama, T., 1966. Electron microscopy on polyp and pigment granules of an ahermatypic coral, Dendrophylla cribosa. Biol. J. Okayama Univ. 12, 69-80.

Kawaguti, S., 1969. Electron microscopy on a soft coral, Heteroxenia elisabethae Kölliker. Biol. J. Okayama Univ. 15, 25-35.

Kingsley, R.J., Watabe, N., 1982a. Ultrastructural investigation of spicule formation in the gorgonian Leptogorgia virgulata (Lamarck) (Coelenterata, Gorgonacea). Cell Tiss. Res. 223, 325-334.

Kingsley, R.J., Watabe, N., 1982b. Ultrastrucutre of the axial region in Leptogorgia virgulata (Cnidaria, Gorgonacea). Trans. Amer. Micr. Soc. 101, 325-339. 
Kinglsey, R.J., and Watabe, N., 1983. Analysis of proteinaceous components of the organic matrices of spicules from the gorgonian Leptogorgia virgulata. Comp Biochem. Physiol. B. Biochem. Mol. Biol. 76, 443-447.

von Koch, G., 1887. Fauna und Flora des Gulfes von Neapel und der angrenzenden Meeresabschnitte. XV. Monographie: Die Gorgoniden. Mittheilungen der Zoologischen Station zu Neapel. Friedländer \& Sohn. Berlin.

Kükenthal, W., 1919. Gorgonaria, zweite hälfte: Allgemeiner Teil. Wissenschaftliche Ergebnisse der Deutschen Tiefsee-Expedition auf dem Dampfer "Valdivia" 1898-1899. 13. Band, Zweiter Teil.

Lentz, J.L., Barrnett, R.J., 1961. Enzyme histochemistry of Hydra. J. Exp. Zool. 147, 125-149.

Menzel, L.P., Lee, I.H., Sjostrand, B., and R.I. Lehrer, 2002, Immunolocaization of clavanins in Styela clava hemocytes. Dev. Comp. Immunol. 26:505-515.

Muscatine, L., Tambutté, E., Allemand, D., 1997. Morphology of coral desmocytes, cells that anchor the calicoblastic epithelium to the skeleton. Coral Reefs 16, 205-213.

Murdock, G.R. 1978. Circulation and digestion of food in the gastrovascular system of gorgonian octocorals (Cnidaria; Anthozoa). Bull. Mar. Sci. 28(2): 363-370.

Nutting, C.C., 1889. Contribution to the anatomy of gorgonidae. Univ. Iowa Lab. Nat. Hist. Bull. 1:97-160.

Olano, C. T., 1993. Cellular aspects of alloimmunity and other responses in the gorgonian Swiftia exserta. Thesis (M.S.) Florida International University,

Parker, B.C., Diboll, A.G., 1966. Alcian stains for histochemical localization of acid and sulfated polysaccharides in algae. Phycologia. 6, 37-46.

Reynolds, E.S., 1963. The use of lead citrate at high $\mathrm{pH}$ as an electron-opaque stain in electron microscopy. J. Cell Biol. 17, 208-212. 
Satterlie, R.A., and J.F. Case. 1978. Neurobiology of the gorgonian coelenterates, Muricea californica and Lophogorgia chilensis. II. Morphology. Cell Tiss. Res. 187:379396.

da Silveira, F.L., van't Hof, T., 1977. Regeneration in the gorgonian Plezaura flexuosa (Cnidaria, Octocorallia). Bijdragen tot de Dierkunde 47, 98-108.

Szmant-Froehlich, A., 1974. Structure, iodination and growth of the axial skeletons of Muricea californica and M. fruticosa (Coelenterata: Gorgonacea). Mar. Biol. 27, 299306.

Tidball, J.G., 1981. Lipoprotein secretion during the formation of the axial skeleton in Leptogorgia virgulata (Cnidaria: Gorgonacea). Cell Tiss. Res. 219, 327-338.

Tidball, J.G., 1982a. Fine tructural aspects of anthozoan desmocyte development (Phylum Cnidaria). Tiss. Cell 14, 85-96.

Tidball, J.G., 1982b. An ultrastructural and cytochemical analysis of the cellular basis for tyrosine-derived collagen crosslinks in Leptogorgia virgulata (Cnidaria: Gorgonacea). Cell Tiss. Res. 222, 635-645.

Tiffon, Y., Hugon, J.S., 1977. Localisation ultrastructurale de la phosphatase acide et de la phosphatase alkaline dans le cloisons septales steriles de l'anthozoaire Pachycerianthus fimbriatus. Histochem. 54, 289-297.

Tucker, R.P, Shibata, B., Blankenship, T.N., 2011. Ultrastructure of the mesoglea of the sea anemone Nematostella vectensis (Edwadsiidae). Invert. Biol. 130, 11-24.

Weil, R., 1934. Contribution a l'Étude des Cnidaires et de leurs Nématocystes. I. Recheres sur les Nématocystes (Morpholigie, Physiologie, et Développement).Travaux de la Station Zoologique de Wimeraux. Tome X. p 1-701. 
APPENDIX I

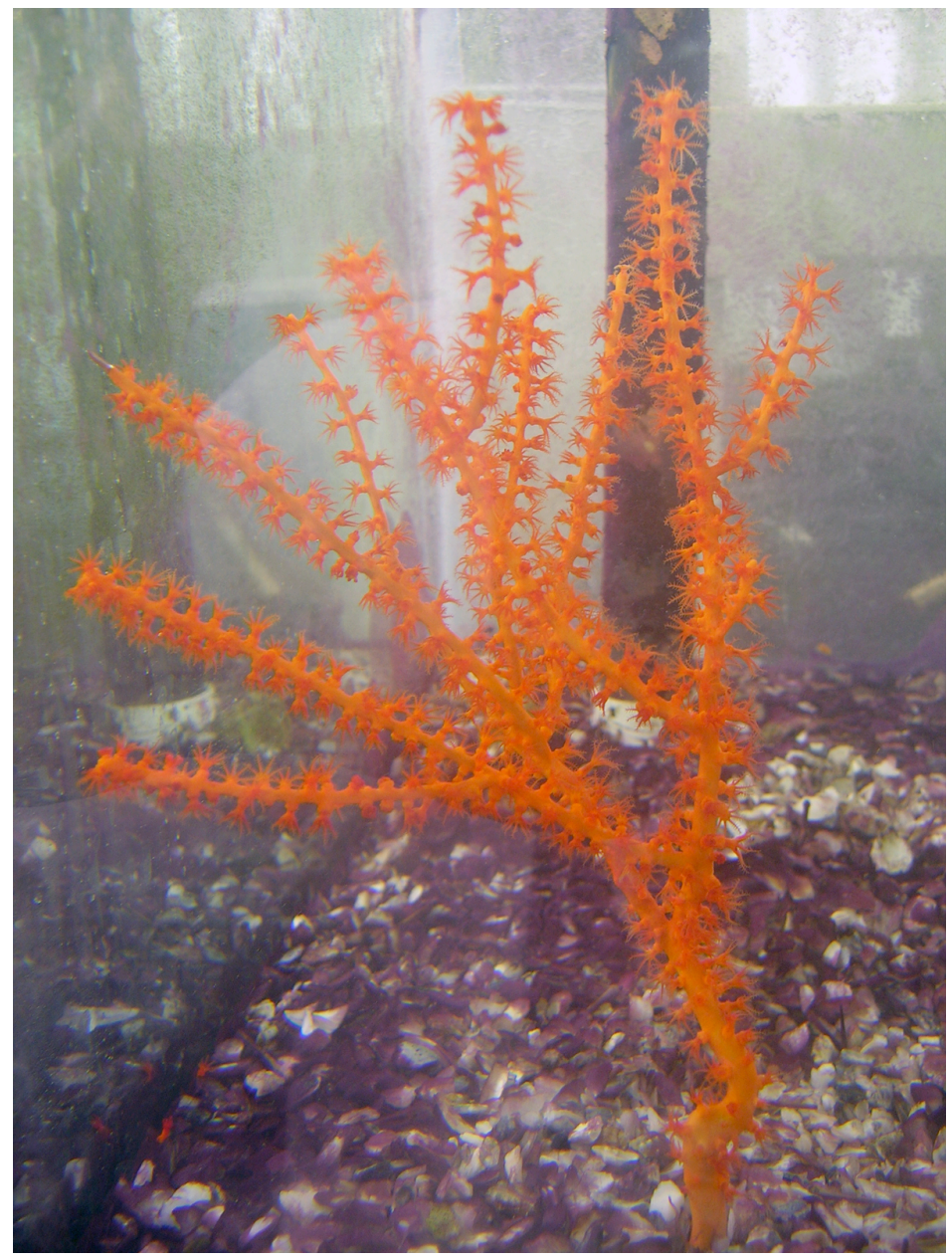

Figure 1a. Colony of Swiftia exserta in holding aquarium.

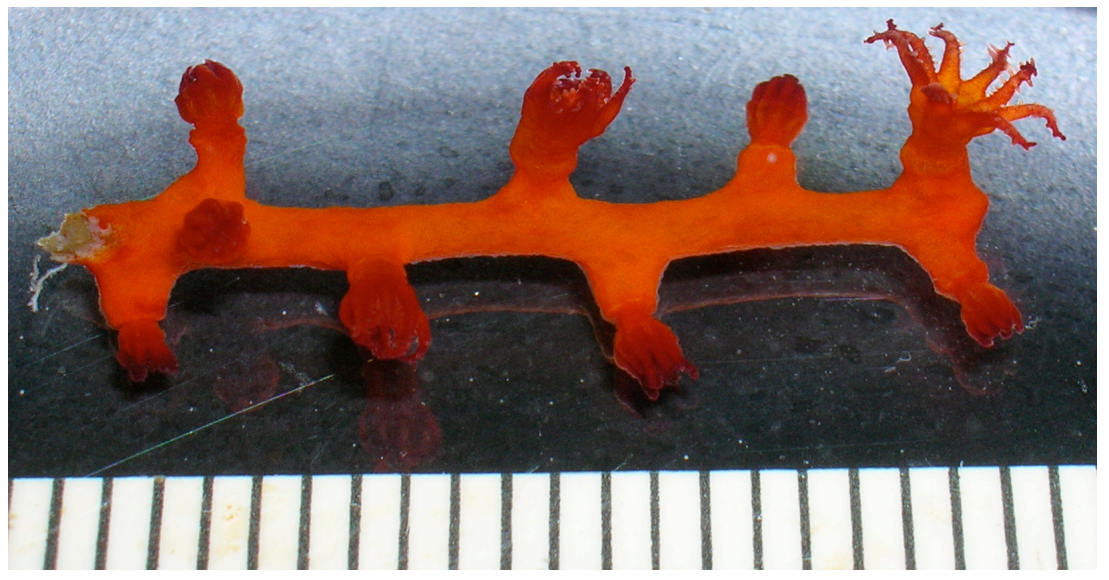

Figure 1b. Cut Swiftia exserta branchlet in artificial sea water. Scale is in millimeters. 


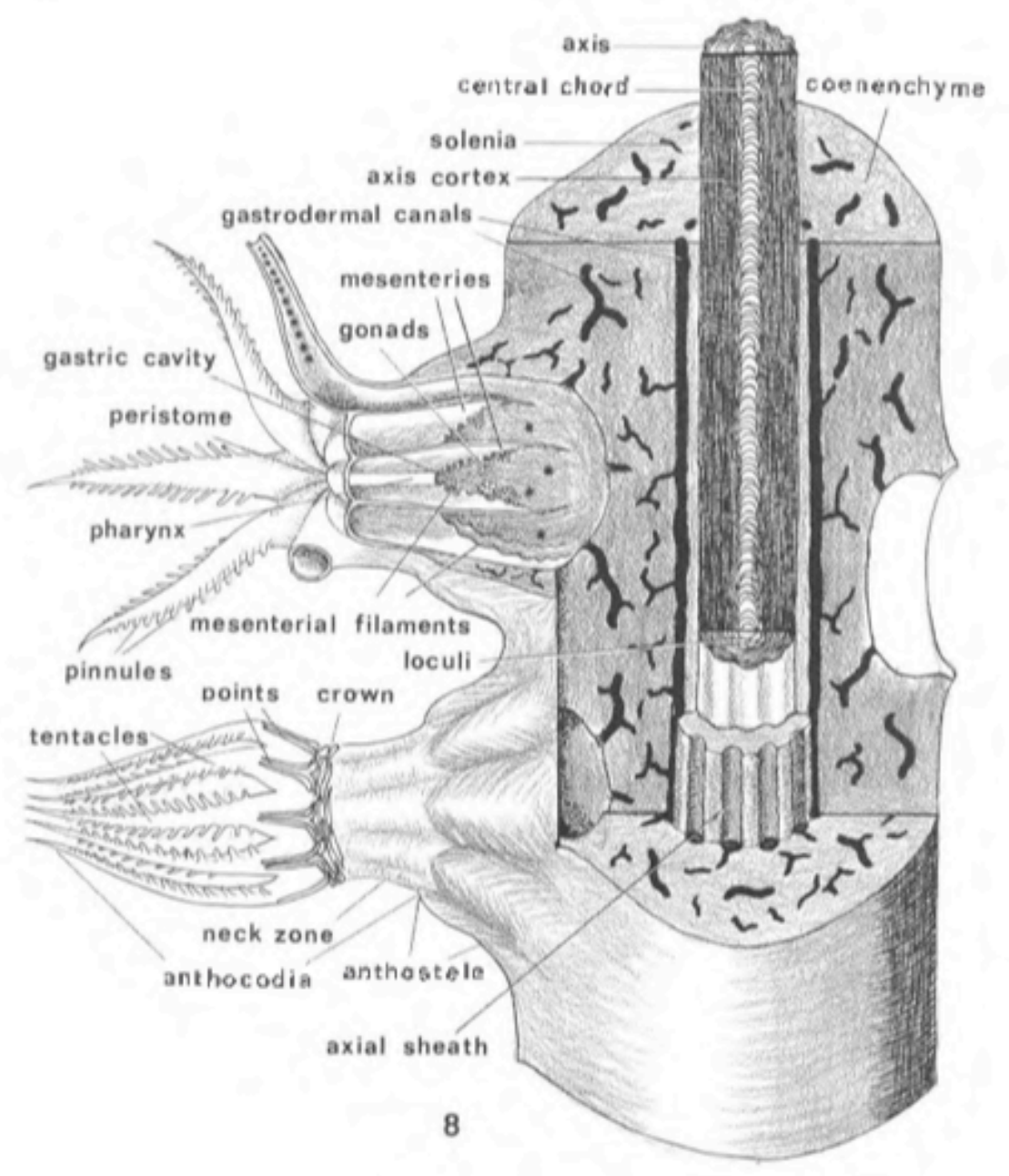

Figure 2. Diagram representation of an octocoral, from Bayer, Grasshoff, and Versefvldt, 1983. 

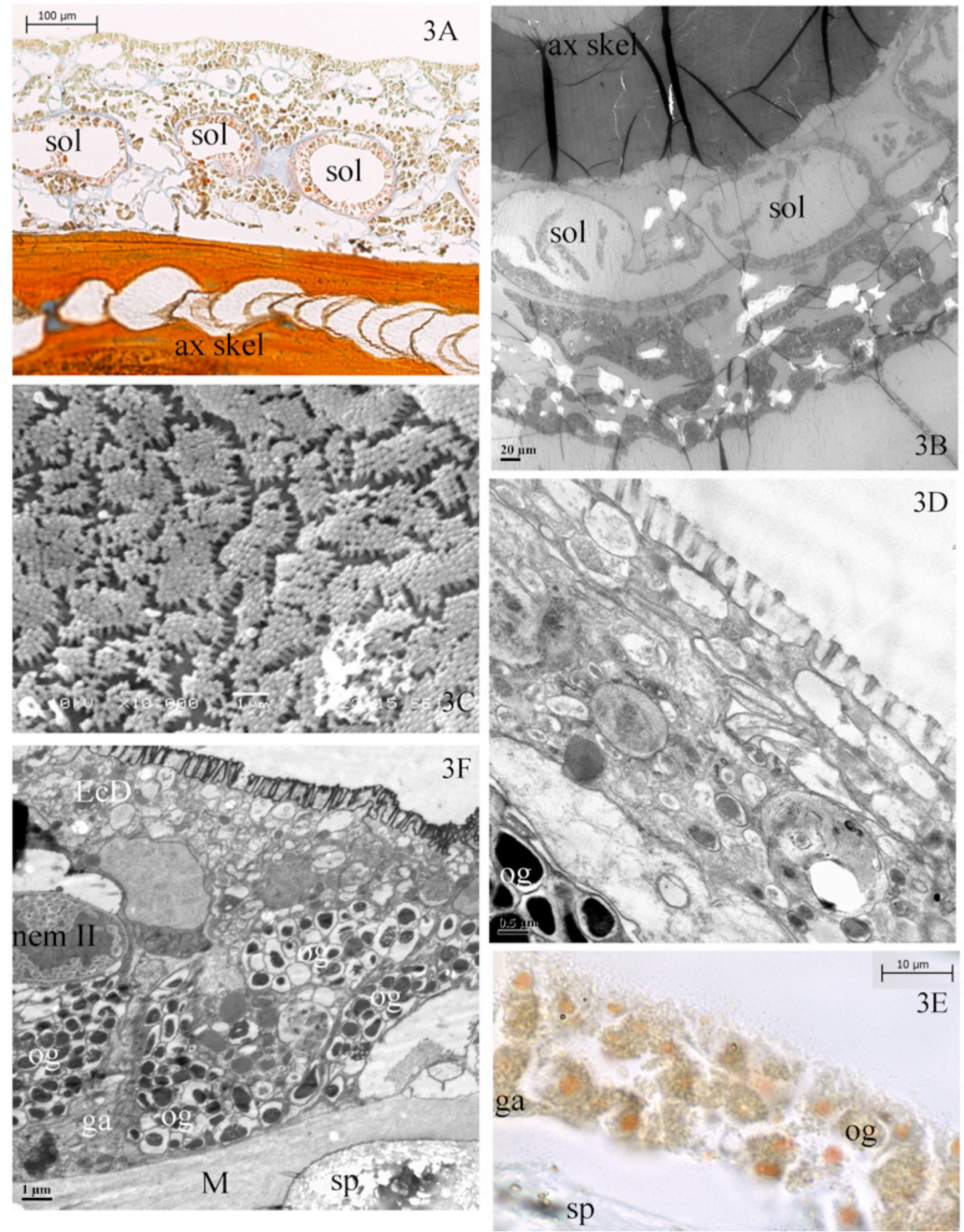

Figure 3. Coenenchyme and ectoderm. Fig 3A shows a longitudinal paraffin section stained with Mallory's aniline blue connective tissue stain. The hollow axial skeleton is visible at the bottom, several circular solenia are located in the mesoglea between the skeleton and the outer rind of cells. 3B is a cross section viewed by TEM., again the 
hollow skeleton is visble (now at top left) surrounded by solenia, mesogleal cell cords, and the outermost ectoderm. White spaces are areas where sclerites were. 3C (middle left image) shows the microvilli on the surface of the coenenchyme by SEM. 3D uses TEM to show the microvilli in cross-section and the thin, flattened ectoderm cells filled with electron-lucent granules. 3E shows a Mallory stained paraffin section with the microvilli of the ectoderm visible. Ectoderm cells cover many oblong granular cells on some granular amoebocytes. 3F gives a survey of the stratified rind of the coenenchyme - thin ectoderm cell at top covering oblong granular cells with electron-dense granules and amorphously shaped granular amoebocytes. At left is a type II nematocyst. Oblong granular (og) cells and granular amoebocytes (ga) are indicated in the panels. 

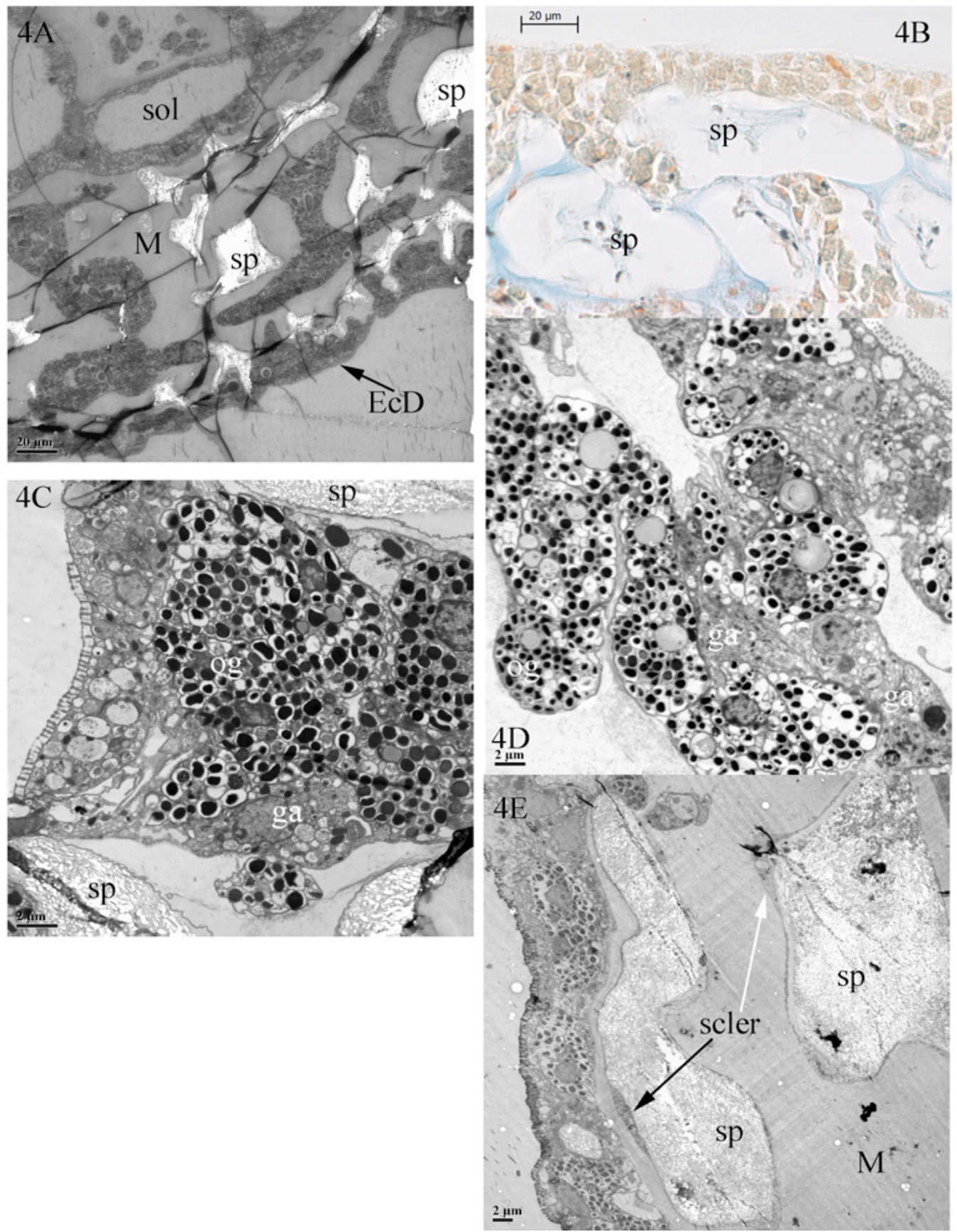

Figure 4. Cell cords in the coenenchyme with embedded spicules (sclerites). 4A shows an overview, by TEM, of the cellular architecture of the coenenchyme from the ectoderm into the mesoglea in cross section. In 4B, a Mallory stained paraffin section, the dense packing of the mesogleal cell cords around the spicules is apparent in this partially decalcified section. 4C and 4D show, by TEM, the irregularly shaped cell cords filled with oblong granular cells (with electron-dense granules), granular amoebocytes (of indeterminate shape and with granules staining less intensely and of different sizes) In 4C the sclerites are very near the surface and ectoderm (at the top and bottom of the image). 
In 4E several sclerocytes can be seen surrounding the lightly stained sclerites that are embedded in the mesoglea. Oblong granular (og) cells, granular amoebocytes (ga), sclerocytes (scler) are indicated in the panels. 

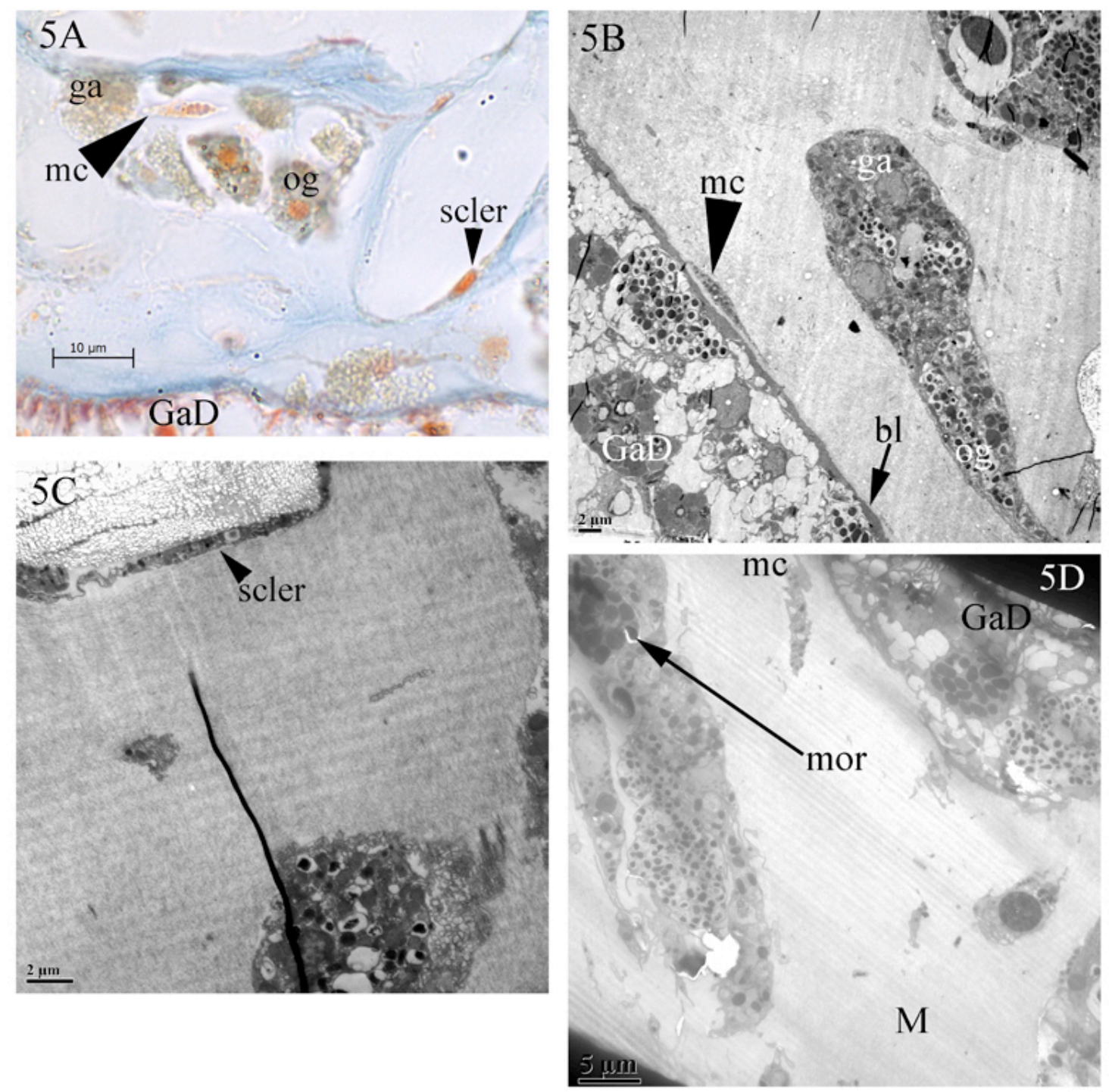

Figure 5. Mesoglea with assorted cells and cell cords. 5A shows the deep blue collagenlike staining with Mallory's. The orange nucleus of a sclerocytes is visible towards the bottom right of the sclerite space (small arrowhead). Several oblong granular cells and granular amoebocytes are clustered at the center of the image, along with one mesogleal cell (large arrowhead). 5B through 5D show the fibrous nature of the mesoglea. Figure $5 \mathrm{~B}$ shows the basal lamina-like separation of gastroderm (thin arrow) and a cell cord. 5C contains part of a sclerite and a sclerocyte (small arrow) filled with many small secretory granules. 5D shows the rather scarce morula-like cells (mor) in a mesogleal cell cord. Oblong granular (og) cells, granular amoebocytes (ga), mesogleal cells (mc), basal lamina-like structures (bl), and sclerocytes (scler) are indicated in the panels. The striations visible in the TEMS are due to knife chatter. 

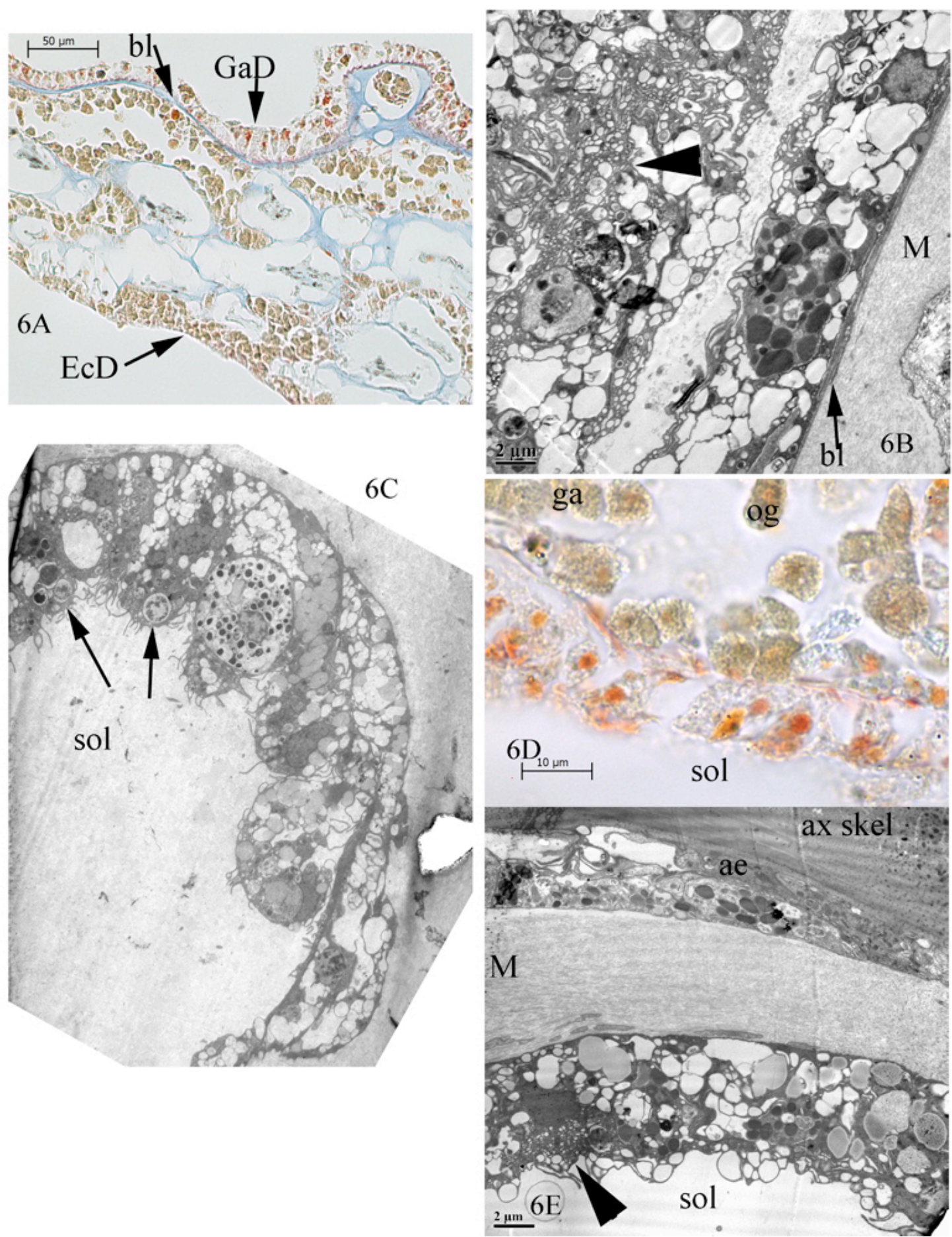

Figure 6 a-e. Solenia type endo/gastroderm. 6A shows solenia-type gastroderm lining at the upper part of the figure in a paraffin section stained with Mallory's. 6B shows an electron micrograph of a compressed solenia that is separated from the mesoglea by a basal lamina-like layer (bl). This layer is faintly visible in 6D and clearly visible in 6C 
and $6 \mathrm{E}$ as well. The arrow head in $6 \mathrm{~B}$ indicates a zymogen-like cell. $6 \mathrm{C}$ is a low magnification TEM of a section through a solenia showing several types of digestive cells. Arrows indicate phagocytic vesicles. Mallory staining in 6D indicates that one of the digestive cell types is acidophilic (bright orange-red granules in cytoplasm). $6 \mathrm{E}$ shows an section of solenia gastroderm with a zymogen-like cell (arrow head) that has an electron-dense cytoplasm and many small electron-lucent granule-like spaces. 6B, C, and D show secretory cells packed with granules, phagocytic cells with membrane ruffles, and flagella are visible in the solenia duct (in cross section) in B.

Oblong granular (og) cells, granular amoebocytes (ga), and basal lamina-like structures (bl) are indicated in the panels. 

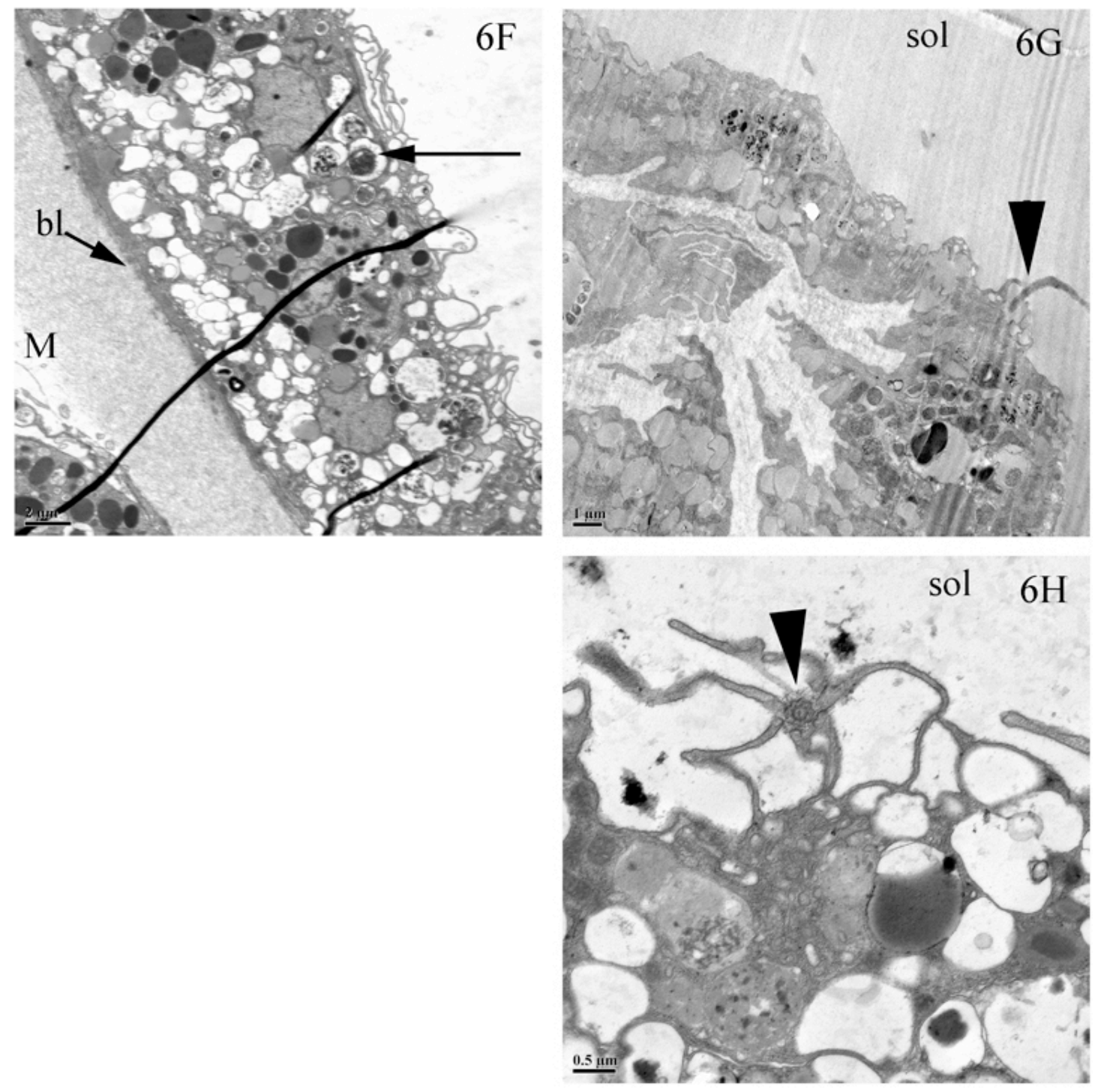

Figure $6 \mathbf{f}$-h. Solenia-type endo/gastroderm, continued. $6 \mathrm{~F}$ shows granular phagocytic cells, a phagocytic vesicle is indicated by the arrow. $6 \mathrm{G}$ and $\mathrm{H}$ show the flagellae that move liquid through the solenia $-6 \mathrm{G}$ shows the collar surrounding the base of the flagella in sagittal section (arrow head), while 6H shows a section perpendicular to the flagella (arrow head) and collar base. Striations in 6G are due to diamond knife chatter likely from building vibrations. 

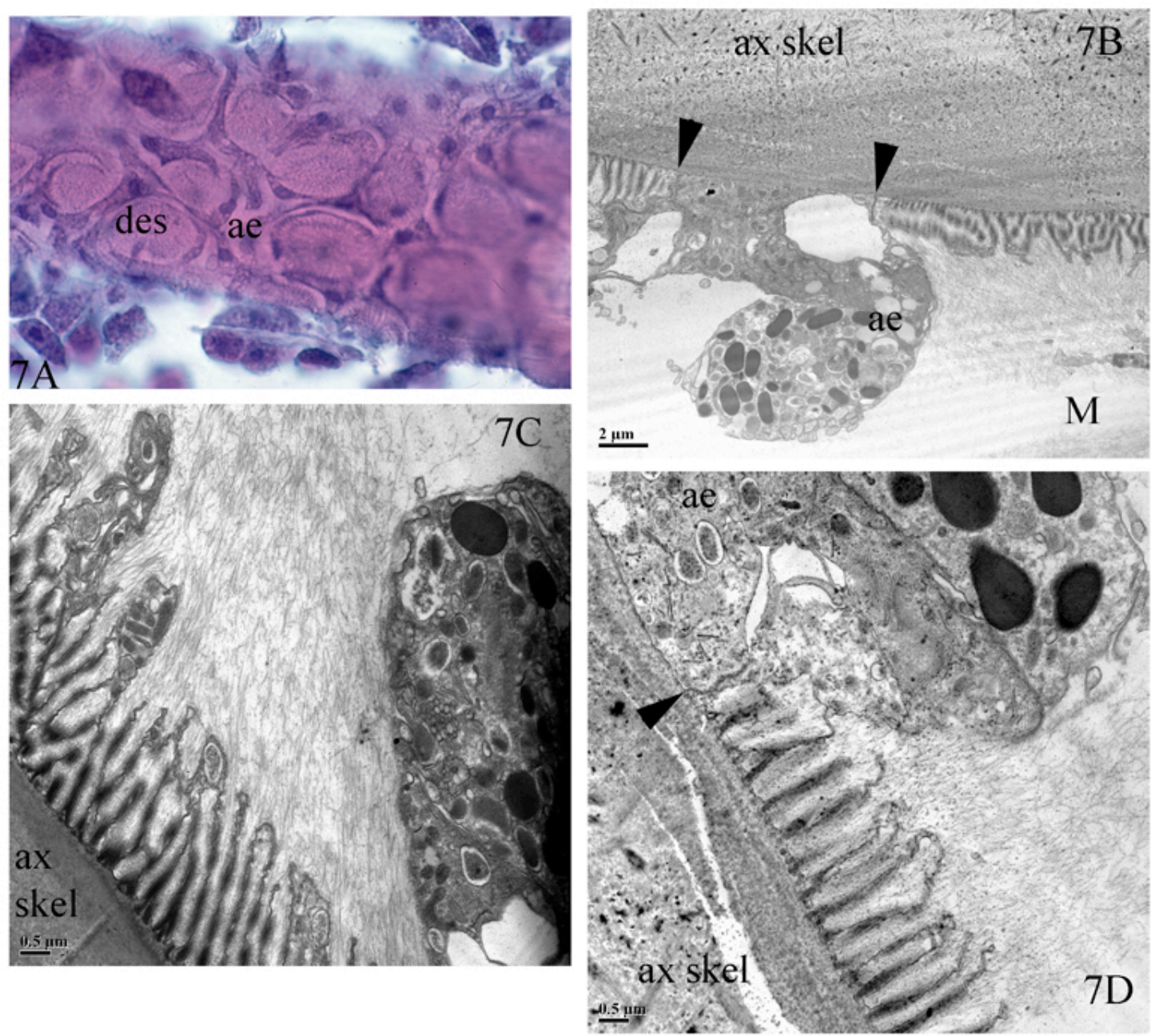

Figure 7. Desmocytes and axial epithelia. 7A show desmocyte plaques and axial epithelia with H\&E staining. 7B-D are TEM images. 7B shows the elevation of the axial epithelial cells above the plane of the desmocytes and an active axial epithelial cell still capable of secreting gorgonin. 7C and 7D show the fine structure of the desmocyte anchors into the mesoglea and the many secretory vesicles and golgi bodies found in the axial epithelial cells. Tight junctions between the desmocyte and axial epithelium cell are indicated by arrow heads in 7B and 7D. 


\title{
Chapter III
}

Initial Functional Characterization, by Enzyme Histochemistry, of the Immunocytes in Swiftia exserta, an Octocoral

\begin{abstract}
Most animals rely on circulating hemocytes as cellular effectors of immunity. These cells have traditionally been characterized on the basis of morphology, function, and cellular contents. Morphological descriptions utilize granule differences, and cell shapes; functional descriptions rely on phagocytic, chemotactic, and cytotoxic abilities, and oxygen transport, while cellular content descriptions include cytochemical features and key enzymes. Key enzymes used to identify phagocytes in tissues include hydrolytic enzymes, peroxidase, and, in invertebrates, phenol oxidase.

Cnidaria, such as our model animal Swiftia exserta, lack circulatory systems complicating the identification of immune effectors cells. To identify the immune effector cells in $S$. exserta we choose the following enzymes because of their colocalization to phagocytes: (1) acid and (2) alkaline phosphatase, (3) non-specific esterase, (4) $\beta$-glucuronidase, (5) peroxidase, and (6) dihydroxy phenylalanine/phenol oxidase. Our results indicate that there are two distinct cell populations that could function as phagocytic immunocytes. Neither cell type morphologically resembles the "granular amoebocytes" of the mesoglea found in cnidaria.
\end{abstract}

Key words: cnidaria, octocoral, innate immunity, immunocyte, enzyme histochemistry, histology 


\section{Introduction}

The effectors of the immune system have traditionally been categorized into two groups: humoral and cellular. In most animals the cellular effectors are circulating and thus readily apparent and easily isolated. The white blood cells from humans, mammals, and other vertebrates have been studied for over a century (Hayhoe and Quaglino, 1994). Studies with some invertebrate blood cells, echinoderm hemocytes, have an even longer history (Metchnikoff, 1891). Many other invertebrate hemocytes have been studied. Arthropod [e.g., Culex pipiens (Wang et al., 2011), Carcinus maenas (Söderhäll and Smith, 1983), and Limulus polyphemus (Copeland and Levin, 1985)], mollusk [Mytilus edulis (Pipe, 1990), Crassostrea virginica (Cheng and Downs, 1988), and Chamelea gallina (Pampanin, et al. 2002)], protochordate (Ballarin and Cima, 2005), and annelid (Stein and Cooper, 1978) hemocytes have been characterized in more recent years. These studies focus on cellular functions (chemo-taxis and phagocytosis) and on cellular contents (hydrolases, (per)oxidases, lysozyme (Söderhäll and Smith, 1983). Human neutrophils have been extensively studied and several reviews list granule contents for the main granule types (Borregard et al., 1993).

Phagocytic cells, such as mammalian neutrophils and macrophages, carry a range of enzymes that digest their ingested targets, usually killing ingested micro-organisms during endocytosis. Colorimetric and heavy-metal deposition reactions have been developed for several of the enzymes involved in killing microbes (e.g., lysozyme and peroxidase) as well as for an array of leukocyte specific hydrolytic enzymes (Hayhoe and Quaglino, 1994; Pearse, 1968, 1970). Different leukocyte enzymes are activated or reach 
optimal activity rates during phagosome maturation as the phago-lysosomal $\mathrm{pH}$ decreases from slightly alkaline to acidic ( 7.8 to below 5$)$.

The phago-lysosome has been shown to contain a variety of hydrolases, including phosphatases (alkaline and acidic), lipases and esterases with varying substrate specificity, and an array of substrate-specific glycosidases (Hayhoe and Quaglino, 1994). These enzymes degrade and digest microbes and other ingested particles.

In many invertebrates, the cellular immune response includes encapsulation of the foreign body in an attempt to isolate the foreign material from host tissue. During the encapsulation process phagocytic cells wrap themselves around the large foreign body in many layers while secreting enzymes and antimicrobials (peptides and compounds). The capsule is firmly held together by melanin produced by the enzyme phenol oxidase (dihydroxyphenylalanine [DOPA] oxidase in vertebrates). The (pro)phenol oxidase system has been extensively studied in marine invertebrates (Smith and Söderhäll, 1991). A series of reports by Mydlarz and co-workers has found several phenol oxidase isotypes in extracts of Caribbean corals (Mydlarz, et al., 2008, Mydlarz and Palmer, 2011).

Cnidarians, which lack a cellular vascular system, have amoeboid-shaped cells, termed "granular amebocytes", which have been reported in the mesoglea (Bigger and Hildemann, 1982). Granular amebocytes have been described in wound infiltrates (Meszaros and Bigger, 1999; Young, 1974) and graft rejection areas (Olano, 1993). On the basis of different metachromatic staining, it has been suggested that "granular amebocytes" are not a homogeneous population (Bigger and Hildemann, 1982). Some of these cells have been shown to be phagocytic (Olano and Bigger, 2000), thus they are viewed as the putative 'immunocytes' in these cnidarians. The term "granular 
amebocyte" in $S$. exserta is misleading however; there are cell types that are clearly granular and cell types that have irregular outlines (some even have granules), but ameboid motion can not be observed since living animals are heavily pigmented and the tissues are opaque.

Since the species of the phylum cnidaria lack a circulatory system, one cannot simply bleed the animals to obtain hemocytes. Additionally, aside from demonstrating phagocytic cells in Swiftia exserta, Olano and Bigger (2000) demonstrated that trauma or injury will change the phagocytic characteristics of cells in this species.

Swiftia exserta is a sessile colonial octocoral that branches from a single stem into many branches at irregular intervals. Polyps are eight-tentacled and embedded into a common fleshy tissue, the cenenchyme, at their base with the polyp's gastric cavity extending into the cenenchyme. The animal's structural support consists of a hollow protein skeleton. Gastric cavities are lined with mesentery filaments, the main sites of digestion that extend from the tentacle bases into the gastric cavity. Mesenteries are attached to the external polyp wall on only one side. Individual gastric cavities are interconnected through the coenenchyme by tube-shaped canals, the solenia. Cnidaria are considered diploblastic animals with a cellular ectoderm and endoderm (gastroderm) separated by an acellular mesoglea (Brusca and Brusca, 2003).

I decided on a functional approach to try to identify some of the potential constitutive phagocytic immunocytes in our model organism. Since hemocytes and leukocytes have for many years been characterized based on their enzyme content I decided to use this approach and choose the following enzymes due to their co-localization to phagocytic hemocytes: (1) alkaline and (2) acid phosphatase, (3) non-specific esterases, (4) $\beta$ - 
glucuronidase, (5) peroxidase, and (6) DOPA/phenol oxidase. The first four enzyme groups are hydrolytic enzymes that aid in the killing and intracellular digestion of microbes (Borregard, et al., 1993; Hayhoe and Quaglino, 1994). Peroxidase is a proxy for the superoxide (respiratory burst) mediated killing system and was one of the first enzymes linked to phagocytes (Fishel, 1910). On the basis of the extensive literature on phenol oxidase function in arthropods I decided that phenol oxidase containing cells in these gorgonians would be good immunocyte candidates.

\section{Materials and Methods}

Maintenance of Animals

Swiftia exserta colonies were collected by Dr. Henry Feddern at 20-30 m depths off Southeast Florida and maintained in 550 gallon closed system aquaria at Florida International University. Commercially available sea salt mixtures were used, with minimal water conditioning achieved with sub-gravel and activated charcoal filters and a protein skimmer. Care was taken to avoid inter-colony contacts. Animals were fed San Francisco Bay brand Artemia nauplii three times weekly (Salter-Cid \& Bigger, 1991). Aquarium temperature was maintained between $18{ }^{\circ} \mathrm{C}-22{ }^{\circ} \mathrm{C}$ and salinity between $35-$ 37 ppt.

\section{Cell and Tissue Processing}

Cryo-Embedding for Enzyme-histochemistry

Ten short, $2-3 \mathrm{~cm}$, branches were harvested from 10 individual colonies and fixed in 2\% paraformaldehyde (Electron Microscopy Sciences) in 0.22 micron filtered sea water (FSW) for 4 hours at room temperature. Tissue was infiltrated with increasing 
concentrations of sucrose $(10 \%, 20 \%, 2$ changes of $30 \%)$ in 0.22 micron filtered sterile sea water (FSW), followed by $30 \%$ sucrose : O.C.T. (Optimal Cutting Temperature, Tissue Tek) (2:1), 30\% sucrose : O.C.T. ( $1: 1)$, and three changes of O.C.T. (the last overnight). Tissues were aligned in fresh O.C.T. in plastic boats and gradually immersed in liquid nitrogen. Serial $6 \mu \mathrm{m}$ sections were cut on a Leica CM 1850 Cryo-Stat at $-25^{\circ} \mathrm{C}$ and collected onto pre-cooled Fisher-brand SuperFrost Plus glass slides.

\section{Paraffin Embedding for Histology}

Tissues were fixed in Helley's fixative (Clark, 1981), rinsed in FSW, decalcified in $2 \%$ ascorbic acid, dehydrated in a graded series of ethanol and embedded in Paraplast at $56{ }^{\circ} \mathrm{C}$. Sectioning was performed on a Reichert-Jung 2800 Frigocut $\mathrm{N}$ cryostat at $-20{ }^{\circ} \mathrm{C}$, using a metal knife to obtain 5-6 $\mu \mathrm{m}$ sections.

\section{Single Cell Suspensions for Enzyme histochemistry}

Short branches were washed 5-10 minutes each in three changes of calcium and magnesium free Artificial Seawater containing 30 mM EDTA (Humphreys, 1963). Tissue was scraped onto 50 micron nylon mesh (folded four times) and washed through the mesh into a collection vessel. The resulting single cell suspension was either (1) used directly for cytospins or (2) washed three times in artificial seawater containing calcium and magnesium (Peddie et al., 1995) and allowed to adhere to cleaned glass slides for 45

minutes. Both cytospin and adherent cells were fixed with $4 \%$ paraformaldehyde (in FSW) for 15 minutes at room temperature. 


\section{Histological Staining}

Mallory's aniline blue collagen stain (Clarke, 1981) was used for general histological staining of paraffin sections. An unstained cryo-section is also used for comparison.

\section{Histochemical Staining}

Enzyme Histochemistry

Traditional recipes, fully detailed in the reference volumes "Histochemistry, Theoretical and Applied" volumes 1 (1968) and volume 2 (1972) by A.G.E. Pearse, and “Enzyme Histochemistry” by J.D. Bancroft and N.M. Hand (1987), were followed.

Peroxidase and DOPA oxidase (phenol oxidase) followed Pearse 1968 and Pearse 1972. Bancroft \& Hand (1987) was used for acid and alkaline phosphatase, and nonspecific esterases. All reagents were purchased from Sigma (St. Louis, MO, USA) unless otherwise specified. The substrates $\alpha$-naphthyl-acetate, naphthyl AS-D chloroacetate and Tween-80 (DifCo) were used for esterase reactions, naphthol AS-BI $\beta$-D-glucuronide for $\beta$-glucuronidase, naphthol AS-BI phosphate and $\alpha$-naphthol phosphate for phosphatases. Diamino benzidine (DAB) and hydrogen peroxide (Fisher) were used to show peroxidase, DL-dihydroxyphenylalanine was used to demonstrate DOPA-oxidase. For the esterase and $\beta$-glucuronidase reactions the incubation $\mathrm{pH}$ was modified: $\mathrm{pH} 5.0,6.0$, and 7.0 were used. Fast Red ITR and Fast Blue RR were used since the animal remains slightly yellowish-orange after processing. Fast Blue RR was dissolved in N,N'-dimethyl formamide, Fast Red ITR in water where appropriate. 


\section{Enzyme Specificity Controls}

Phosphatase inhibitors included: $2 \mathrm{mM}$ sodium orthovanadate, a tryosine phosphatase, ATPase, and a non-specific alkaline phosphatase inhibitor; $20 \mathrm{mM}$ sodium fluoride, a non-specific acid phosphatase inhibitor; $4 \mathrm{mM}$ sodium pyrophosphate, an inhibitor of serine and threonine phosphatases; $50 \mathrm{mM}$ EDTA, which chelates calcium and magnesium essential for phosphatase function; and 250 microM tetramisole, a specific inhibitor of alkaline phosphatase.

Non-specific esterase activity was inhibited by $20 \mathrm{mM}$ sodium fluoride.

Peroxidase inhibitors used were: $20 \mathrm{mM}$ sodium orthovanadate, non-specific peroxidase inhibitor; $20 \mathrm{mM}$ sodium azide, an irreversible myeloperoxidase inhibitor, which also inhibits superoxide dismutase, and catalase; $20 \mathrm{mM}$ sodium cyanide, a reversible inhibitor of cytochrome c oxidase; and a complete inhibition of peroxidase activity with $3 \%$ methanolic hydrogen peroxide.

\section{Quinone and Quinoprotein Detection}

Cytospin preparations and adherent cells were fixed in 4\% paraformaldehyde in seawater, washed twice, and reacted with $0.024 \mathrm{M}$ nitro blue tetrazolium (NBT) in $2.0 \mathrm{M}$ glycine-NaOH buffer, $\mathrm{pH} 10$ protected from light (Paz, et al., 1991).

\section{Process outline}

Tissues were fixed, dehydrated with increasing sucrose concentrations, infiltrated with O.C.T. and snap-frozen in liquid nitrogen. Frozen blocks and sections were stored at 
$-80^{\circ} \mathrm{C}$ until used for enzyme histochemical staining. Single cell suspensions were either allowed to adhere or centrifuged onto slides, then fixed and used for enzyme reactions.

\section{Results}

Histological Staining in paraffin sections

Cytochemical staining of paraffin sections with Periodic Acid-Schiff's reagent stained every part of the animal, including the mesoglea in varying shades of purple. Feulgen's stain similarly stained the sections completely (less intensely than PAS). Data not shown.

Mallory's aniline-blue collagen stain (Clark, 1981) stains paraffin sections intensely (Fig 1a). In Mallory stained sections, the cell nuclei are stained orange, collagenous fibers intensely blue, mucus and amyloid fibers shades of blue, and fibrin red (Clarke, 1981).

Figure 1a shows the coenenchyme tissue loosely organized into a richly cellular mesoglea in which the mesogleal fibers stain intensely blue indicating their collagenous nature, a very thin external ectoderm, and a layer of gastroderm that is only a single columnar cell layer thick. The gastroderm is supported with an external (blue) collagenous layer and an internal (red) fibrin-like layer (similar to the gastroderm of the solenia, see Ch. II) and has a few intensely acidophilic globular gland cells randomly interspersed with poorly staining heavily granular cells. Many cells in the highly folded mesentery filaments in the gastric cavity stain intensely acidophilic and a series of parallel myonemes are visible. Open spaces in the mesoglea are from (partially) decalcified spicules. 
Figure 1b shows an unstained cryo-section: in fact, this is a negative control section for acid phosphatase. Parts of mesentery filaments and the gastric cavity are visible at the top. A lining of solenia-type gastroderm delimits the mesoglea from the gastric cavity, while a thin ectoderm (at the bottom of the figure) separates the mesoglea from the external environment. These sections retain some of the animal's natural orange-brown pigment even after the processing for cryo-sectioning.

\section{Enzyme Histochemistry}

\section{Phosphatases}

The alkaline phosphatase reactions were negative for freshly prepared cells and cryosections, with two different substrates (data not shown). However, the acid phosphatase reaction stained several cell types in both adherent and cytospin cell preparations (Fig 2a, 2b) and several cell types in cryo-sections: irregularly shaped cells with large granules, and amorphous hyaline cells with granules interspersed in the cytoplasm (Fig 2c). Inhibitor controls in cryo-sections indicated the following: sodium orthovanadate and sodium fluoride inhibited all acid phosphatase activity, while sodium pyrophosphate and EDTA restricted positive staining to the solenia gastroderm cells containing large round granules. Reactions performed without substrate convey the residual pigment in the animal.

\section{Esterases}

In the fresh cell preparations the heavily granular cells stained positive with alphanaphthyl acetate in both cytospin and adherent cell populations (Fig 3a, 3b), sodium 
fluoride inhibited this reaction completely. Using cryo-sections, naphthyl AS-D chloroacetate and Tween-80 did not yield any colorimetric reactions at any of the three pHs, whereas $\alpha$-naphthyl acetate yielded strongly positive results at pH 7.0 only (Fig 3c). The inhibitor, sodium fluoride significantly reduces staining in the sub-epithelial layer and inhibits the enzyme isotype in the gastroderm (both solenia and mesentery gastroderm).

\section{Beta-glucuronidase}

Cryo-sections did not stain for this enzyme under any of the $\mathrm{pH}$ conditions tested (data not shown).

\section{Oxidases}

Both oxidases showed distinct positive reactions in cytospin and adherent cell preparations (Fig 4a, 4b; Fig 5a, 5b), both oxidases labeling similar cell types: spherical cells filled with small, round granules, and amorphous hyaline cells with granules interspersed in the cytoplasm. Peroxidase positive cells in cryo-sections were localized mainly in the granular cell layer immediately below the ectodermal epithelia with some cells in the mesogleal cell cords also staining positive (Fig 4c; Fig 5c, 5d). Occasional mesentery gland cells stained as well. Control reactions for peroxidase included sodium orthovanadate (stained the occasional mesentery gastroderm gland cells), sodium azide (no staining), sodium cyanide (no staining), and a complete inhibition of peroxidase activity with $3 \%$ methanolic hydrogen peroxide (as expected, complete inhibition). 


\section{Quinone reactive cells}

The NBT-quinone reaction is strongly positive in cells with few and very large round granules. Weakly positive quino-protein staining is evident in amorphous hyaline cells with granules interspersed in the cytoplasm (Fig 6a, 6b). In cryo-sections quinones and quino-proteins stained blue in the outermost ectodermal epithelia cells and in oblong cells with large granules in the mesogleal cell cords (Fig 6c). Often the positive cells in the mesoglea stained very intensely indicating a high concentration of quinones and quinoproteins.

\section{Experiment Repeatability}

Reactions were repeated three times independently with freshly prepared solutions each time with the same results.

\section{Discussion}

Some cells of the cnidarian mesoglea have historically been reported to include the putative immunocyte (Chapman 1974, Bigger and Hildemann 1982) in the form of "granular amoebocytes". Because these immunocytes have been described as phagocytic, they should be involved in any foreign body response and wound healing and thus carry antimicrobial substances (enzymes, peptides and oxidative burst capacity). Here we localized a number of enzymes associated with white blood cells (leukocytes in chordates) to the layer of amorphous, highly granular cells just beneath the squamous ectodermal epithelia and in similar cells dispersed within the mesoglea in S. exserta. Ours is the first report localizing any enzymes in an octocoral, and the first to detect enzymes 
in the clonal tissue between polyps in any cnidarian (hard coral, soft coral, or hydroid). Hydrolytic digestive enzymes such as acid phosphatase and several esterases, along with peroxidase are sequestered in granule-packed cells in the mesoglea immediately below the ectodermal epithelia cells. Only the oxidases and quinones (readily available reactive oxygen) are found in the granular cells further into the mesoglea and closer to the axial skeleton. This augments the findings by Olano and Bigger (2000) that describe phagocytic cells at two hours and at 24 hours post-injury (cut or thread insertion). These authors noted that injury dramatically altered the cell types capable of phagocytosis histology on two hour post-injury sections showed that 'granular amoebocytes' were the sole phagocytic cell type, while at 24 hours post-injury internalized particles were detected in many cell types (ectoderm, gastroderm, sclerocytes, 'granular amoebocytes', and mesogleal cells). We label the 'mesogleal cells', 'globular granular cells', and 'granular amebocytes' from this earlier report (Olano and Bigger, 2000) as 'oblong granular cells' here.

The solenia-type gastroderm in the coenenchyme has many acid phosphatase positive cells, indicating the likely presence of acidic vesicles (possible lysosomes and phagolysosomes). A few of these cells also stain for peroxidase and non-specific esterase supporting a digestive function for this tissue. DOPA oxidase was not detected in cells in the gastroderm (neither in solenia nor in mesentery) since phenoloxidase is not involved with digestion.

Many of the oblong granular cells in the mesoglea stain positive for acid phosphatase to varying degrees indicating that this enzyme is used for several purposes not only host defense. This phosphatase, in combination with oxidases has served as a marker for 
"professional phagocytes," the phagocytic immune cells such as macrophages and neutrophils in mammals (Borregard et al., 1993). The scattered non-specific esterase, peroxidase, DOPA oxidase, and quinone positive cells infused throughout the cell cords in the mesoglea seem ideally situated to migrate to sites of need.

In the cells immediately below the ectodermal epithelia there are possibly two cell types: mainly digestive cells, and mainly defensive cells. Many of the granular cells beneath the ectodermal epithelia contain acid phosphatase and esterase, but not the oxidases - these cells may serve either in nutrition (Mariscal and Bigger, 1977) or in host defense. Those cells in this sub-epidermal layer that contain acid phosphatase, esterase, and the oxidases indicate that an immune function takes precedence in these oblong granular cells.

Cells positive for acid phosphatase, non-specific esterase, peroxidase, and DOPA oxidase in cytospin and adherent cell preparations are primarily compact, irregularlyshaped cells with many large amorphous granules. A smaller percentage of amorphous hyaline cells with granules interspersed in the cytoplasm also stain positive for acid phosphatase, quinones, and peroxidase. This second cell population is likely derived from the solenia-type gastroderm since one of the cell types found there also stains with the same enzymes, but has a greater cytoplasm-to-granule volume than the oblong granular cells found in the mesogleal cell cords.

The overlap in cellular shape, structure, and location strongly support the notion that many mesogleal cells can function as immunocytes, but that the thin ectoderm layer does not harbor phagocytic immunocytes. On the basis of these experiments we can only speculate that other immunocyte types could be present. However, the presence of 
quinones, potent redox capable molecules, in the outermost ectodermal epithelia may provide a first line of defense against invading pathogens susceptible to oxidative damage.

As a result of the activation cascade required for phenol oxidase the DOPA oxidase reaction stains much more strongly in the freshly prepared single cell suspensions than in the cryo sections. These cells have been shocked by calcium and magnesium withdrawal and by mechanical forces (pressure and shear) before being tested for DOPA oxidase activity.

This separation of enzyme localization suggests the presence of at least two cell types involved in cellular innate immune responses: a layer in the immediate exterior area where likely incursions will have penetrated the thin ectoderm, and a wandering cell type responding to deeper injury that may encapsulate offending material. In addition, the thin ectoderm may use quinones or quino-proteins as a first line of defense. Studies on the morphology, histology, and ultrastructure of Swiftia exserta are currently being conducted.

As noted by Elie Metchnikoff (1893) and more recently by Thomas Bosch's group hydrozoa are quite different from anthozoa. Augustin and Bosch (2010) reviewed the potential immune responses in Hydra ssp. and concluded that in this simple cnidarian the immune reactions are limited to focal responses in either the ectoderm or the endoderm (aka gastroderm). In Hydra sp. (and hydrozoa) these tissue layers are only one cell thick and are separated by a very thin mesoglea. Swiftia exserta and perhaps other anthozoa seem to have two cell populations to defend tissue integrity: the focal response cells 
immediately sub-epithelial, and the migrating DOPA-oxidase containing cells deeper in the mesoglea.

Acknowledgments

LPM thanks Cecile Tondo (Olano) for excellent paraffin sections, and the FIU Tissue Culture Core Facility for use of the Leica CM 1850 Cryo-Stat.

\section{References}

Augustin R, Bosch TCG. Cnidarian Immunity: A Tale of Two Barriers. Adv. Exp. Med. Biol. 708: 1-16, 2010.

Ballarin L, Cima F. Cytochemical properties of Botryllus schlosseri haemocytes: indications of morpho-functional characterization. Eur. J. Histochem. 49: 255-264, 2005.

Bancroft JD, Hand NM. Enzyme Histochemistry. Oxford University Press. Oxford, UK., 1987.

Bigger CH, Hildemann WH. Cellular defense systems of the Coelenterata. In: Cohen N, Sigel M (Ed.) The Reticuloendothelial System. Plenum Press, New York, 59-87, 1982.

Borregard N, Lollike K, Kjeldsen L, Sengeløv H, Bastholm L, Nielsen MH, et al. Human neutrophil granules and secretory vesicles. Eur. J. Hematol. 51: 187-198, 1993.

Brusca RC, Brusca GJ. Invertebrates. Sinauer Assoc., Sunderland, MA., 2003. 
Chapman DM. Cnidarian Histology. In: Muscatine Lenhoff L, HM (Ed.), Coelenterate Biology. Reviews and New Perspectives. Academic Press, New York, San Francisco, London, 2-92, 1974.

Cheng TC, Downs JC. Intracellular acid phosphatase and lysozyme levels in subpopulations of oyster, Crassostrea virginica, hemocytes. J. Invert. Path. 52: 163$167,1988$.

Clark G. Staining Procedures. Williams and Wilkins, Baltimore, 1981.

Copeland DE, Levin J. The fine structure of the amoebocyte in the blood of Limulus polyphemus. Morphology of the normal cell. Biol. Bull. 169: 449-457, 1985.

Fischel R. Der histochemische Nachweis der Peroxydase. Wiener klin. Wochenschr. 44: $1557,1910$.

Hayhoe FGJ, Quaglino D. Haematological Cytochemistry. Third Edition. Churchill Livingstone. London, UK., 1994.

Humphreys T. Chemical dissolution and in vitro reconstruction of sponge cell adhesions. Isolation and functional demonstration of the components involved. Dev. Biol. 53: 27-47, 1963.

Mariscal RN, Bigger $\mathrm{CH}$. Possible ecological significance of octocoral epithelia ultrastructure. In: Taylor DL (Ed.) Proc. Third Int. Coral Reef Symp. Rosenstiel School of Marine and Atmospheric Science, Miami, 127-133, 1977.

Meszaros A, Bigger $\mathrm{CH}$. Qualitative and quantitative study of wound healing processes in the coelenterate, Plexaurella fusifera: spatial, temporal, and environmental (light attenuation) influences. J. Invert. Path. 73: 321-331, 1999. 
Metchnikoff E. Lectures on the Comparative Pathology of Inflammation: delivered at the Pasteur Institute in 1891. Kegan Paul, Trench, Trübner \& Co. London, UK., 1893.

Mydlarz L, Holthouse SF, Peters EC, Harvell CD. Cellular Responses in Sea Fan Corals: Granular Amoebocytes React to Pathogen and Climate Stressors. PLoS ONE 3(3): e1811, 2008.

Mydlarz L, Palmer CV. The presence of multiple phenol oxidases in Caribbean reefbuilding corals. Comp. Biochem. Physiol. A Mol. Integr. Physiol. 159: 372-378, 2011.

Olano CT Cellular aspects of alloimmunity and other responses in the gorgonian Swiftia exserta. Thesis (M.S.) Florida International University, 1993.

Olano CT Bigger CH. Phagocytic activities of the gorgonian coral Swiftia exserta. J. Invert. Path. 76: 176-184, 2000.

Pampanin DM, Martin MG, Ballarin L. Morphological and cytoenzymatic characterization of the haemocytes of the venus clam Chamelea gallina. Dis. Aquat. Organ. 49: 227-234, 2002.

Paz MA, Flückinger R, Boak A, Kagan HM, Gallop PM. Specific Detection of Quinoproteins by Redox-cycling Staining. J. Biol. Chem. 266: 689-692, 1991.

Pearse AGE. Histochemistry, Theoretical and Applied, second edition. Volume 1. Churchill Press. London, UK., 1968.

Pearse AGE. Histochemistry, Theoretical and Applied, second edition. Volume 2. Churchill Press. London, UK., 1972. 
Peddie CM, Riches AC, Smith VJ. Proliferation of undifferentiated blood cells from the solitary ascidian, Ciona intestinalis, in vitro. Dev. Comp. Immunol. 19: 377-387, 1995.

Pipe, RK. Hydrolytic enzymes associated with granular haemocytes of the marine mussel Mytilus edulis. Histochem. J. 22: 595-603, 1990.

Salter-Cid L, Bigger CH. Alloimmunity in the gorgonian coral Swiftia exserta. Biol. Bull. 181: $127-134 ; 1991$.

Smith VJ, Söderhäll K. A comparison of phenol oxidase activity in marine invertebrates. Dev. Comp. Immun. 15: 251-261, 1991.

Söderhäll K, Smith VJ. Separation of the haemocyte populations of Carcinus maenas and other marine decapods, and prophenoloxidase distribution. Dev. Comp. Immun. 7: 229-239, 1983.

Stein EA, Cooper EL. Cytochemical observations from the earthworm, Lumbricus terrestris. Histochem. J. 10: 657-678, 1978.

Wang Z, Lu A, Li A, Shao Q, Beerntsen BT, Liu C, et al. A systematic study on hemocyte identification and plasma prophenoloxidase from Culex pipiens quinquefasciatus at different developmental stages. Exp. Parasit. 127: 135-141, 2011.

Young JA. The nature of tissue regeneration after wounding in the sea anemone Calliactis parasitica (Couch). J. Mar. Biol. Assoc. UK., 54: 599-617, 1974. 


\section{APPENDIX II}

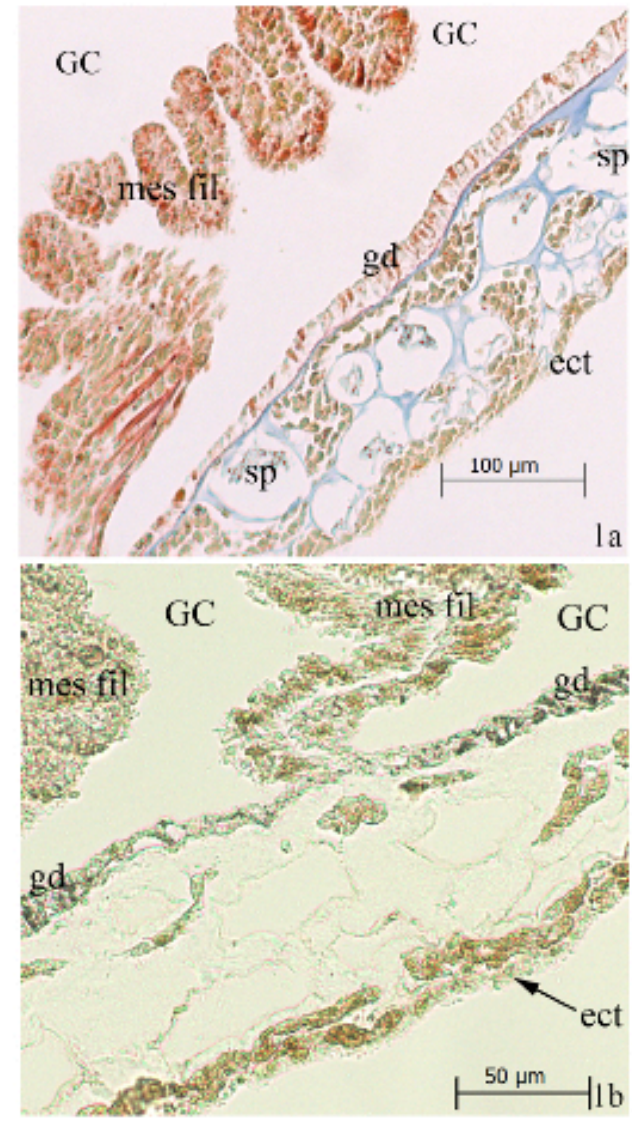

\section{Figure 1. Normal Tissue and Control Sections}

Fig 1A. Paraffin section of Swiftia exserta, through polyp base at coenenchyme interface, stained with Mallory's aniline blue collagen stain. Mesentery filaments (mes fil) in the gastric cavity (GC) top and left, coenenchyme tissue bottom and right (thin layer of solenia gastroderm-type tissue (gd) bordering gastric cavity and coenenchyme). Spicule (sp) remnants in empty cavities are seen interspersed throughout the mesoglea. The ectoderm (ect), seen at bottom right, is the outer layer of the animal and interacts with the ocean environment.

Fig 1B. Unstained cryo-section of Swiftia exserta. The gastric cavity (GC) is subdivided by mesentery filaments (mes fil) and is lined with solenia-type gastroderm (gd). The translucent mesoglea (not labeled) contains cell cords that wind throughout and abut the ectoderm (ect). Note that many cells in the mesoglea are naturally light brown, and that several cell types in the solenia-type gastroderm have highly refractile contents. This section does not show spicules (sp). This is a negative control section for acid phosphatase. 


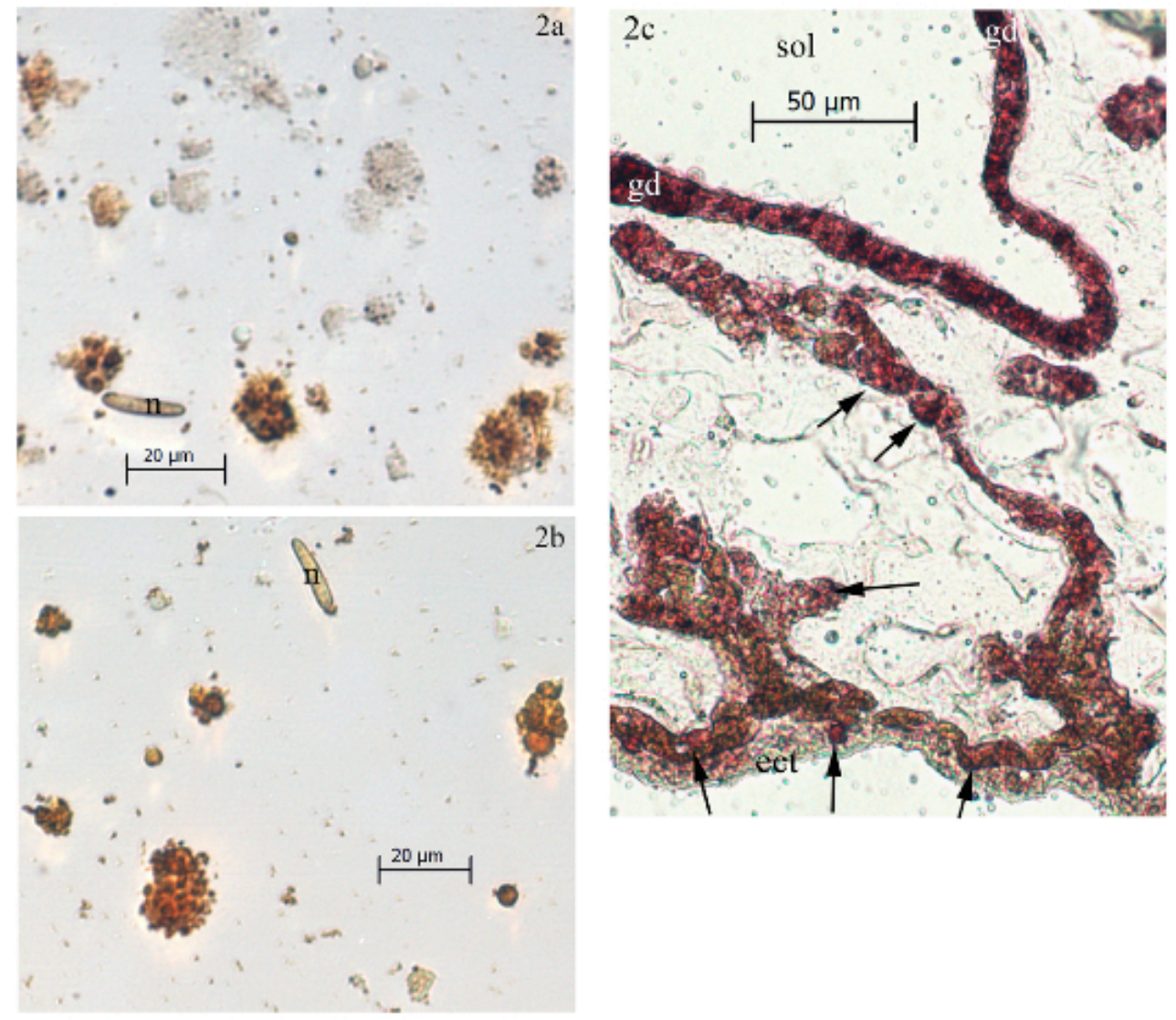

\section{Figure 2. Acid Phosphatase}

Fig 2A. Cytospin single cell suspension stained for acid phosphatase with $\alpha$-naphthol phosphate and Fast Red ITR. Note thin nematocyst (n), high percentage of granular cells staining positive, and that approximately $50 \%$ of the cells contain acid phosphatase. Fig 2B. Adherent single cell suspension stained for acid phosphatase as in $2 \mathrm{~A}$. Almost all adherent cells stain for acid phosphatase and contain granules.

Fig 2C. Acid phosphatase stained cryo-section. Solenia-type gastroderm (gd) surrounding a solenium (sol) stain intensely. Cells in the mesoglea and abutting the ectoderm (ect) contain acid phosphatase. Ectoderm cells do not contain this enzyme. 

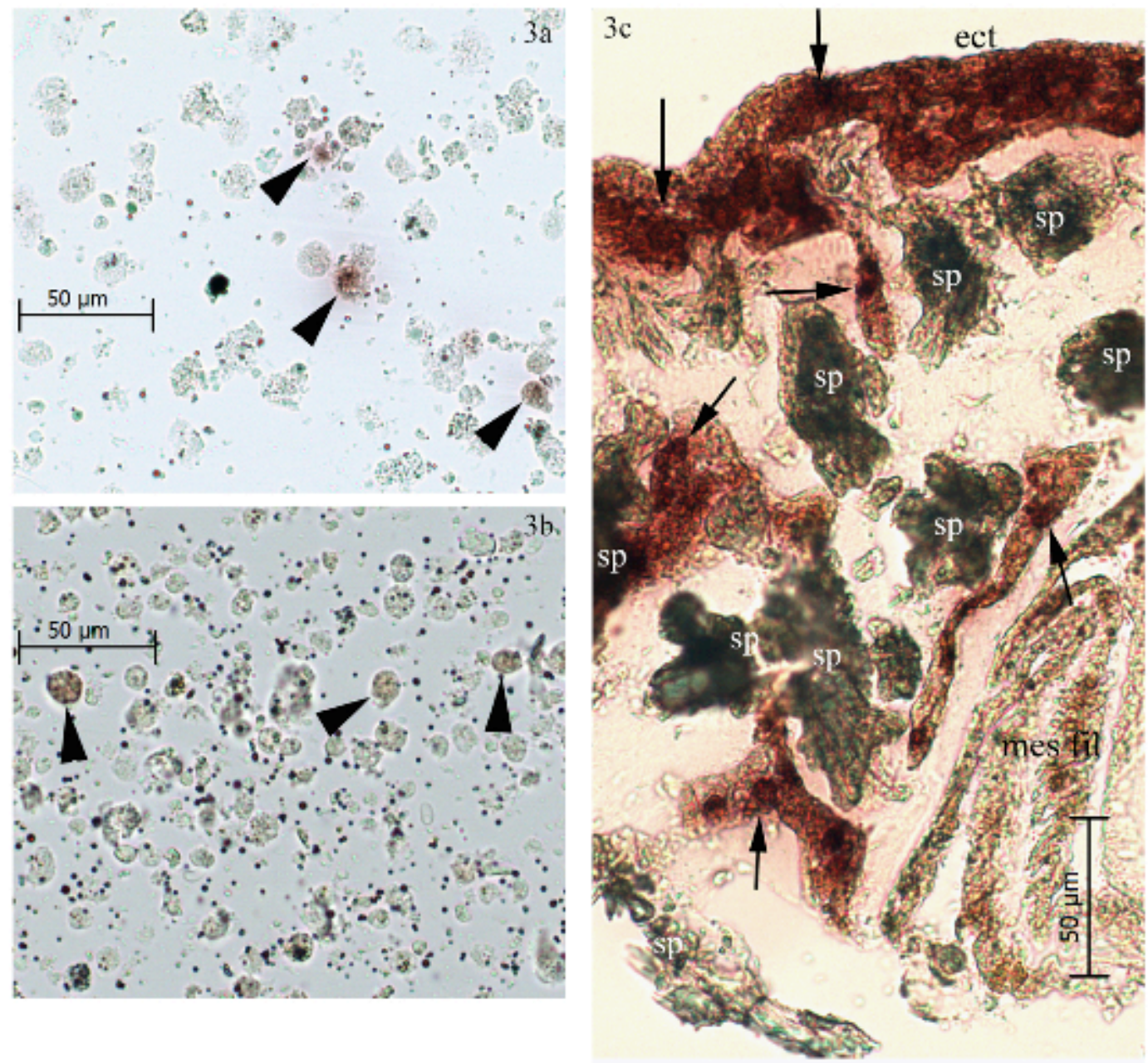

\section{Figure 3. Non-specific esterases}

Fig 3A. Non-specific esterase stain using $\alpha$-naphthol acetate with single cell suspension deposited onto slides via cytospin. Positive cells are indicated by arrow heads.

Fig 3B. Adherent single cell suspension stained with $\alpha$-naphthol acetate for non-specific esterase. Positive cells labeled as above.

Fig 3C. Cryo-sections stained for non-specific esterase with $\alpha$-naphthol acetate. Cells in the ectoderm (ect) and some of the cells in mesogleal cell cords do not stain, whereas other cells in the mesoglea (arrows) stain red for non-specific esterase. Spicules (sp) remain dark gray-black in the non-decalcified sections. A few cells in the mesentery filaments (mes fil) also stain for non-specific esterase. 


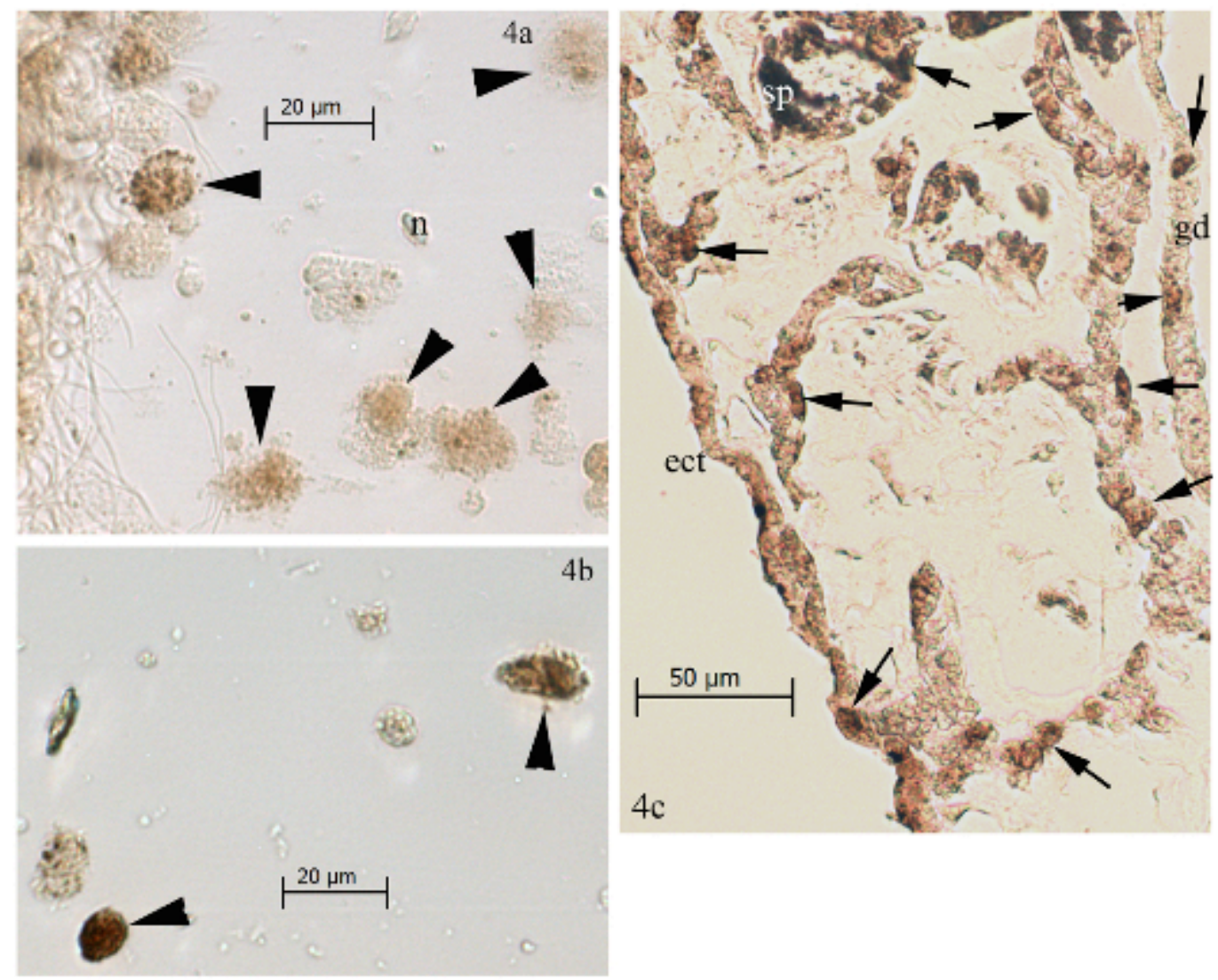

\section{Figure 4. Diaminobenzidine Peroxidase}

Fig 4A. DAB peroxidase stained cytospin preparations of single cell suspension. Large arrowheads indicate positive staining of differing intensities. A small nematocysts (n) is also visible. The clump of cells on the left edge contains many cells and remnants of discharged nematocysts (thin fibrils).

Fig 4B. Adherent cells from single cell suspension stained with DAB for peroxidase. A much higher percentage (nearly $90 \%$ ) of adherent cells stain for peroxidase.

Fig 4C. DAB peroxidase stain in cryo sections. Two cell types in the solenia-type gastroderm (gd) carry peroxidase, while isolated cells in the mesogleal cell cords stain for peroxidase. Occasional ectoderm (ect) cells stain intensely with DAB. A dark gray-black spicule (sp) remains in this section. 


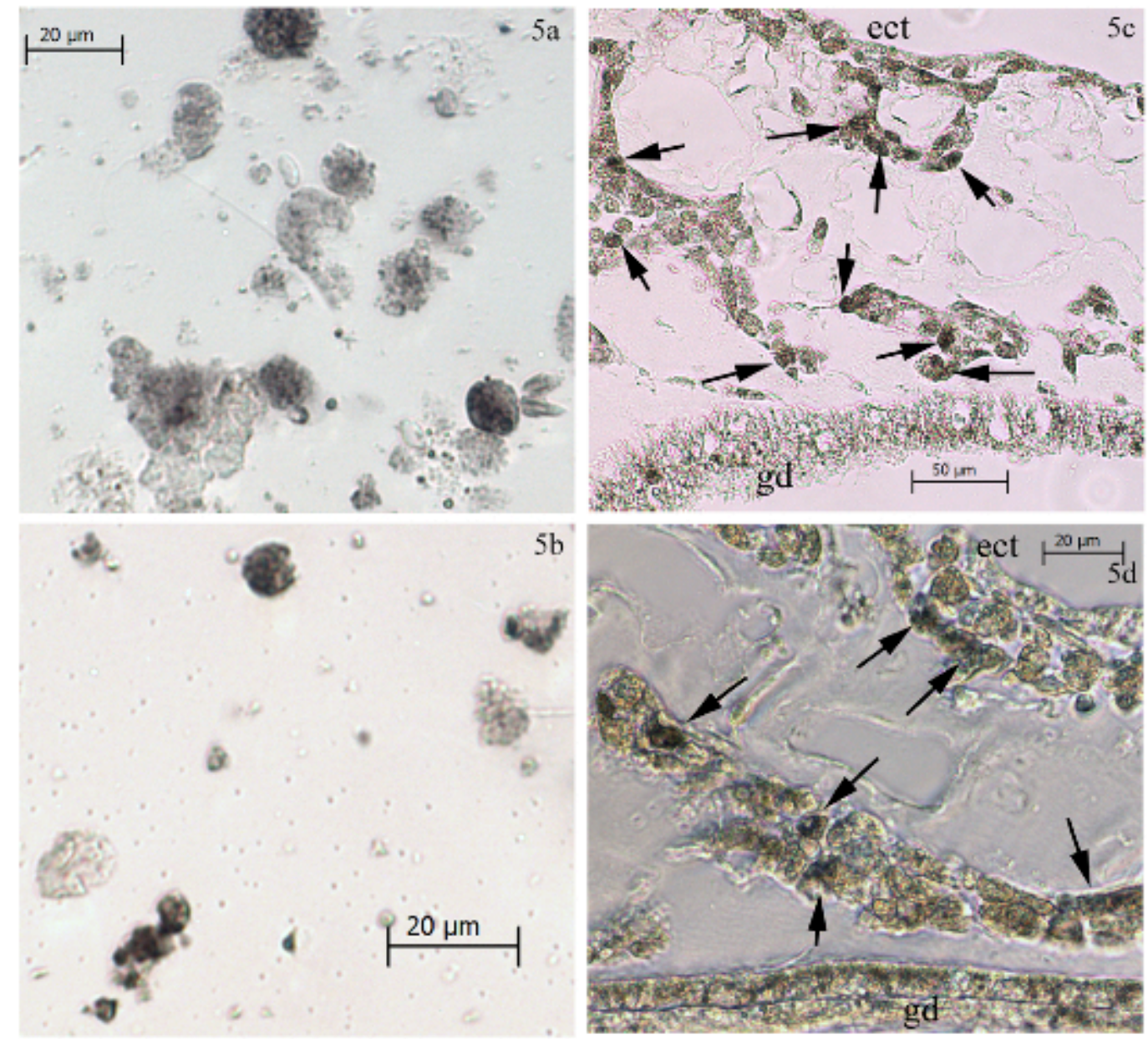

\section{Figure 5. DOPA oxidase}

Fig 5A. DihydrOxyPhenylAlanine (DOPA) oxidase stain of a cytospin preparation from single cell suspension. Many granular cells stain weakly, but a few round, heavily granular cells stain strongly with melanin.

Fig 5B. Adherent cells from a single cell suspension stained with DL-DOPA. Round, heavily granular cells and a disrupted cell with large granules contain strong melanin deposits indicating presence of DOPA-oxidase.

Fig 5C and 5D. Cryo-sections stained for DOPA-oxidase. Staining is absent from the ectoderm (ect) and the solenia-type gastroderm (gd). Cells interspersed in the cell cords of the mesoglea and adjacent to the ectoderm stain for DOPA-oxidase in these sections. 

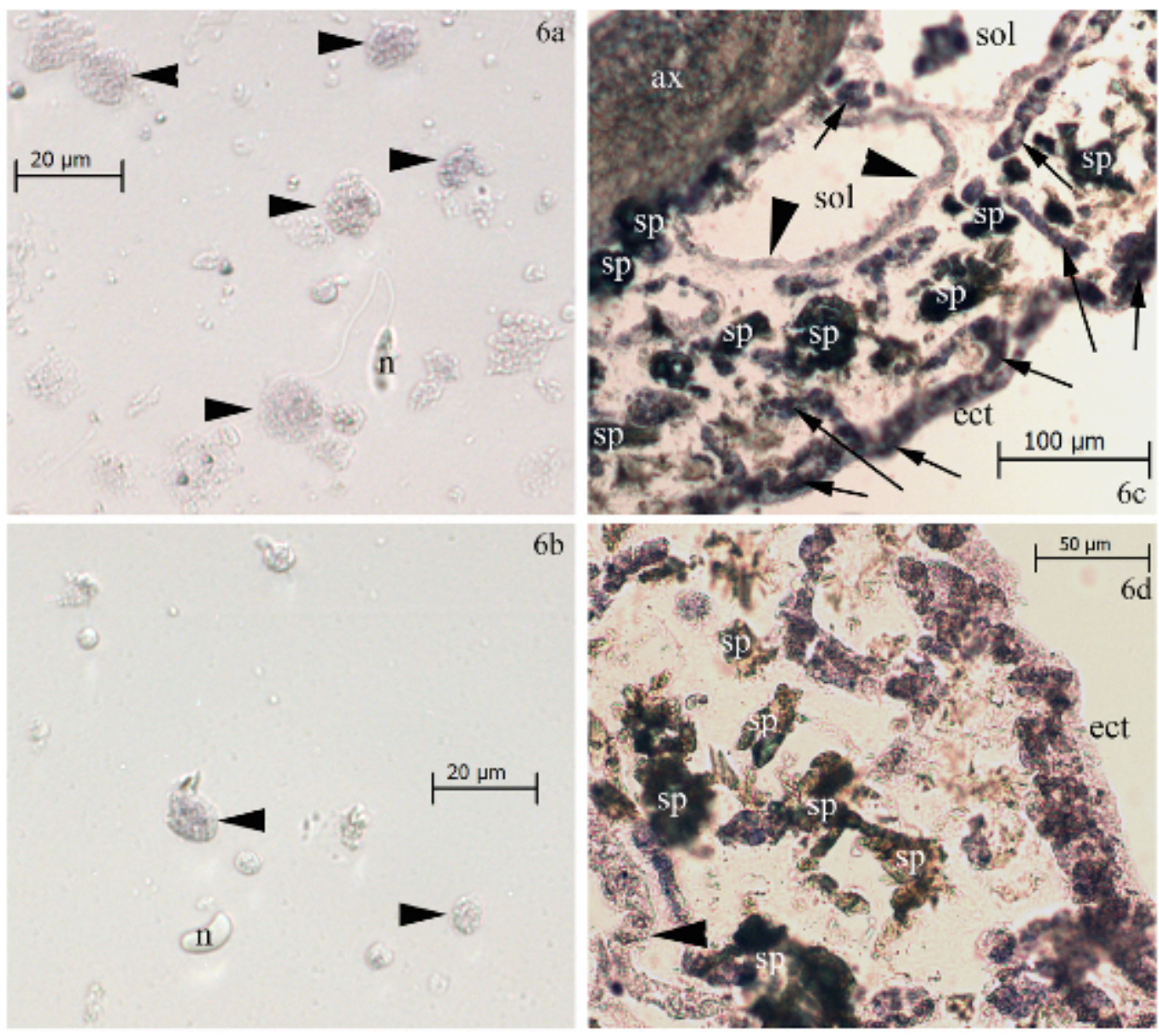

\section{Figure 6. Quinone and Quino-proteins}

Fig 6A. Cytospin preparations of single cell suspensions stained with alkaline nitro-blue tetrazolium for quinines (and quinoproteins). Large arrowheads indicate the weakly stained granular cells (common with this stain) interspersed among non-staining cells (not labeled). Most of the stained cells are rounded, a few have a less defined shape. A discharged nematocyst (n) has some highly refractive material near the thread end of the capsule.

Fig 6B. Adherent cells from a single cell suspension preparation stained for quinines. A round granular cell stains darker than a small round granular cell (arrowheads). The undischarged kidney-shaped nematocyst (n) seems transparent here.

Fig 6C and 6D. Quinone stained cryo-sections show intense staining in the oblong granular cells within the mesoglea (not labeled) and immediately below the ectoderm (ect). Arrowheads indicate the solenia-type gastroderm (gd) lining the solenia (sol) that does not stain for quinines. Arrows in 6C indicate quinone containing cells. Spicules (sp) remaining in these sections are a dark gray-black. The thin ectoderm (ect) in $6 \mathrm{C}$ seems to contain quinines while the thin ectoderm in $6 \mathrm{D}$ does not stain for quinones. Fig $6 \mathrm{C}$ is part of a section cut perpendicularly to the hollow axial skeleton, part of which is seen at the top left (ax). 


\title{
Chapter 4
}

\section{Swiftin, a Broad-Spectrum Antibacterial Peptide from an Azooxanthellate}

\section{Octocoral}

\begin{abstract}
Endogenous small antimicrobial proteins (and peptides) are important components of the innate immune response of animals. Antimicrobial peptides are widespread and have been found in all living organisms studied. Since our understanding of the evolution of innate immunity is not well developed, particularly such responses in cnidaria, my dissertation reasearch endeavors to study some of these immune responses in the octocoral Swiftia exserta (an azooxanthellate ahermatypic anthozoan).
\end{abstract}

The survival of sessile marine animals depends heavily on an efficient mechanism to protect themselves against infection/colonization by the multitude of microbes in the surrounding water column. To study the proteinaceous effectors of Swiftia's antimicrobial defense we prepared crude extracts in acidified water and tested for antibacterial activity with the two-stage radial diffusion assay (RDA). Several fractions exhibited potent antibacterial activity against gram-negative (Escherichia coli, Pseudomonas aeruginosa), and gram-positive (Staphylococcus aureus, Listeria monocytogenes) bacteria.

Two proteins with broad-spectrum antibacterial activity against both Grampositive and Gram-negative bacteria were purified by preparative electrophoresis. Of the two fractions demonstrating antibacterial activity, the later-eluting protein demonstrated considerably higher activity than the earlier-eluting protein and was the focus of 
subsequent investigations. It is this protein that I propose to name Swiftin. Swiftin is a large peptide with a mass of 4695.67 $\mathrm{Da}$ and with sequence similarity to beta-defensins.

\section{INTRODUCTION}

Sessile marine organisms are susceptible to infection from microbes in the surrounding water column and octocorals such as Swiftia exserta are no exception. Recent studies have shown that the water column and coral surfaces are rife with microbes (Brück et al. 2007). Precipitous world-wide coral reef decline has been linked to a variety of bacterial pathogens and environmental stressors, yet little research has been published in an effort to understand one of the most basic principles of host defense of anthozoans - antimicrobial peptides.

Studies on Hydra ssp. by the Bosch group indicate that the two epithelial layers (ectoderm and endo/gastroderm) of Hydra are responsible for host defense against infection (reviewed in Augustin and Bosch 2010). The three antibacterial peptides (arminin 1a, hydramacin-1, and periculin-1) are specific to one epithelial layer: the entoderm (Augustin et al. 2009, Augustin and Bosch 2010). While Hydra ssp. have only these two cellular layers (the mesoglea is acellular) many octocorals, such as Swiftia exserta, have a thick mesoglea that is infiltrated with cords of richly granular cells that have been implicated in wound healing (Meszaros and Bigger 1999) and allograft rejection (Olano, 1993). The first antimicrobial peptide from a cnidarian, Aurelin was, in fact, isolated from mesogleal cells of the moon jellyfish Aurelia aurita (Ovchinnikova et al. 2006). More recently, Damicornin, an antibacterial peptide has been reported from the hard coral Pocillopora damicornis challenged with the coral pathogen Vibrio 
coralliilyticus (Vidal-Dupiol et al. 2011). These authors show that damicornin is localized to epidermal granular cells. Clearly there are a multitude of cell types that can be involved in host defense in various cnidaria, hence we are using a "whole animal" extraction to screen for antibacterial activity.

Other marine invertebrates have yielded antimicrobial peptides from their hemocytes, a "whole animal" approach was not needed since the immunocytes of these animals are readily apparent and easily isolated. The hemocytes isolated from protochordates studied have yielded antimicrobial peptides from the solitary tunicates: plicatamide (Tincu, et al., 2003) from Styela plicata; styelins (Lee, et al., 1997b) clavanins (Lee at al., 1997a) from Styela clava; Halocynthia aurantium has an array of antimicrobial peptides, inluding halocidin (Jang, et al., 2002), dicynthaurin (Lee, et al., 2001), halocynthin and papillosin (Galinier, et al., 2008); and the peptide named CiMAM-A24 has been characterized from Ciona intestinalis (Fedders, et al., 2008). Arthropods are another well-studied phylum of marine invertebrates within the context of antimicrobial peptides. Hemocytes are again used as the starting cell types for these studies. Order chelicerata has has yielded several antimicrobial peptides: tachyplesins and 'big defensin', which were first found in the hemocytes of the Japanese horseshoe crab Tachypleus tridentate (Nakamura, et al., 1988; Saito, et al., 1995), and, not to be outdone, the American horseshoe crab, Limulus polyphemus, hemocytes carry polyphemusin (Mikata, et al., 1989). Homarin has been isolated from the American lobster, Homarus americanus (Battison, et al., 2008), while hyastatin and arasin 1 have been isolated from the hemocytes of Hyas aranesa, the spider crab (Sperstad, et al., 2009b, and Stensvåg, et al., 2008). Hemocytes from the spider crab and from other crabs 
have crustins (Sperstad, et al., 2009a). The penaeidin-family of antimicrobial peptides was first discovered in the white shrimp, Penaeus vannameii by Destoumiex (1997) and has since been found in many other decapod crustaceans (reviewed in Cuthbertson, et al., 2008).

In the order mollusca, the best studied species is Mytillus edulis. Hemocytes of M. edulis have been shown to carry defensins, mytilin, and mytimycin (Charlet, et al., 1996). Among the mollusks, the gastropods have only two candidate species that have been investigated for antimicrobial peptides: the sea hare Dolobella auricularia which has the beta-sheet peptide dollabellanin B2 (Iijima, et al., 2003), and the snail Rapana venosa whose 11 peptides were not named and fully characterized (Dolashka, et al., 2011). Destoumieux-Garzon has since isolated 'big defensins' from pacific oyster Crassostrea gigas hemocytes and linked the large array of antimicrobial peptides in C. gigas to homeostasis of the microbiota in this animal (reviewed in Schmitt, et al., 2012).

Stensvåg's group, that has been studying chelicerates in arctic waters off Norway, has also isolated several antimicrobial peptides from an echinoderm, the sea urchin Strongylocentrotus droebachiensis coelomocytes (their equivalent for hemocytes) that carry strongylocins ( $\mathrm{Li}$, et al., 2008) and centrocins (Li, et al., 2010).

Naming conventions for antimicrobial peptides are based on two criteria: peptide properties or peptide sources. Thus investigators can use three acceptable categories when naming novel antimicrobial peptides: 1) Property based, such as LL-37 (a 37 residue peptide starting with two Leucines, [Gudmundsson, 1996]); 2) Source based, such as styelins and clavanins (from the tunicate Styela clava (Lehrer et al. 2003); and 3) 
combining both property and source, such as So-D1 (a defensin derived from spinacia oleracea [Segura et al., 1998]).

Many of these aforementioned peptides can easily be sorted into the major structural classes of antimicrobial peptides: 1) beta-sheet structures (disulfide bond stabilized hairpin structures), 2) arginine-proline rich peptides that usually assume an alpha-helical shape and have 6 or more positively charged amino acids, or 3) more moderately positively charged peptides that are of indeterminate shape until these peptides insert into membranes. Defensins (Schröder, 2010), protegrins (Kokryakov, et al., 1993), tachyplesin (Nakamura, et al., 1988; Miyata, et al., 1989), polyphemusins (Miyata, et al., 1989), big defensins (Saito, et al., 1995), crustins (Sperstad, et al., 2009a), homarins (Battison, et al., 2008), strongylocins (Li, et al., 2008), dollabelanin B2 (Iijima, et al., 2003), mytilins (Charlet, et al., 1996) are all beta-sheet structure assuming a hairpin-like shape that is stabilized by multiple intramolecular disulphide bonds (anywhere from 2-6 disulphide bridges per molecule). Intermediate between the solely beta-sheet or alpha-helix structure are the penaeidins (Cuthbertson, et al., 2008), which have both cystein-rich and proline-rich domains. Several of the peptides from Halocynthia aurantium are also intermediate in structure: Dicynthaurin is alpha-helical and forms homo-dimers with another molecule of dicynthaurin via a single cysteine present in each molecule (Lee, et al., 2001). Halocidin follows this pattern of helical peptides with a single cysteine forming intermolecular disulphide bridges except that it forms heterodimers between the 15-mers and 18-mers of halocidin (Jang, et al., 2002).

The alpha helical peptides include arasin-1, a proline rich helical peptide (Stensvåg, et al., 2008), the styelins and clavanins from Styela clava (Lee et a., 1997a; 
1997b), the peptides from Halocynthia papillosa - halocyntin and papillosin (Galinier, et al., 2008), and the active antimicrobial peptide from hCAP-18 - LL-37 (Agerbert, et al., 1995; Cowland, et al., 1995; Larrick, et al.,, 1995).

In addition, many vertebrate antimicrobial peptides can be grouped by gene arrangement and primary translation product into two groups: cathelicidins, which have several domains in common; and a mixed-bag group of 'not cathelicidins'. Cathelicidin antimicrobial peptides have been identified in most vertebrates (reviewed in Wang et al., 2011), including agnathans (Uzzell, et al., 2003). Zanetti (2005) established this class of antimicrobial peptides and reviews the structural features common to the cathelicidin family. These consist of a two highly conserved domains: the signal peptide and the Cathelin propiece (a cysteine protease inhibitor). The active antimicrobial peptides display an incredible structural diversity, but all have potent antimicrobial activity. Each mammal studied contains at least one alpha-helical antimicrobial peptide, but many vertebrates' cathelicidins also include beta-sheet and proline-arginine rich active peptides (reviewed in Zanetti, 2005). In many vertebrates the gene structure of their respective cathelicidins has been determined.

Swiftia exserta (Cnidaria, Anthozoa, Octocorallia, Alcyonacea) was initially described by Ellis and Solander (1786) and later classified as the genus type-species by Duchassaing and Michelotti (1864). This soft coral species is an attractive model system for anthozoans since Swiftia exserta has an internal skeleton and no symbiotic zooxanthellae. In addition, there seems to be a limited bacterial flora associated with Swiftia exserta (pers. obs.). This lack of zooxanthellae and associated microbiota means that any antibacterial peptides/proteins isolated from this octocoral are encoded solely in 
the genome of Swiftia exserta, obviating some of the steps needed to identify the origins of damicornin as elaborated in the elegant report by Vidal-Dupiol et al. (2011).

To date most antibacterial activity from gorgonians has been isolated from organic extracts and has thus been characterized as due to organic compounds (see Chen, et al. 2011 for an example). One early study (Burkholder and Burkholder 1958) indicated antimicrobial activity with aqueous and organic extracts but there was no follow-up of the aqueous extracts. In the present study, my approach has been to look for proteins or peptides with antibacterial activities by using aqueous extracts.

\section{METHODS}

\section{Purification and Characterization Outline}

Full details are listed after the accompanying flow-chart.

Branchlets from several randomly selected Swiftia exserta colonies were combined, the tissues and cells disrupted by sonication in acidified water, the resultant slurry stirred overnight at $4^{\circ} \mathrm{C}$ to completely extract granules, and the resultant extract finally clarified by high-speed centrifugation to remove nuclei and other large cellular debris. This procedure produces an aqueous extract of mainly proteins and peptides free of most lipids, large organelles, and longer nucleic acids. Spicules and the axial skeleton are also removed during centrifugation.

To separate the proteins in this crude extract I used two methods of polyacrylamide gel electrophoresis: acetic acid-urea (AU) and sodium dodecyl sulfate (SDS) PAGE. Acetic acid-urea polyacrylamide gel electrophoresis (AU-PAGE) 
separated proteins and peptides primarily by positive charge (the acetic acid present protonates the proteins completely) while SDS PAGE separates proteins primarily by size (the denatured and extended proteins are complexed in a direct linear relationship with the anionic detergent SDS before electrophoretic separation). Following the initial separation utilizing preparative AU-PAGE the proteins were purified further to homogeneity with Reverse-Phase High Pressure Liquid Chromatography (RP-HPLC) by taking advantage of protein species specific hydrophobic interactions with the C-18 (18 carbon chain hydrocarbon attached to silica spheres) packing resin in the HPLC column.

During each step from crude extract to purified protein every fraction generated was tested for bactericidal activity against four bacteria strains (two Gram-positive and two Gram-negative bacteria). Some salt was added during the testing conditions to increase stringency during the screening process since salts, specifically anions, generally reduce antimicrobial activity.

In order to determine the identity of the two fractions found to have significant antibacterial activity I decided to use the ultra-sensitive mass-spectrometry based sequencing methods - these methods not only give accurate masses for the parent ions (the whole proteins) but also provide internal peptide sequences due to initial in vitro trypsin digestion and in-machine fragmentation. 


\section{Purification Flow chart}

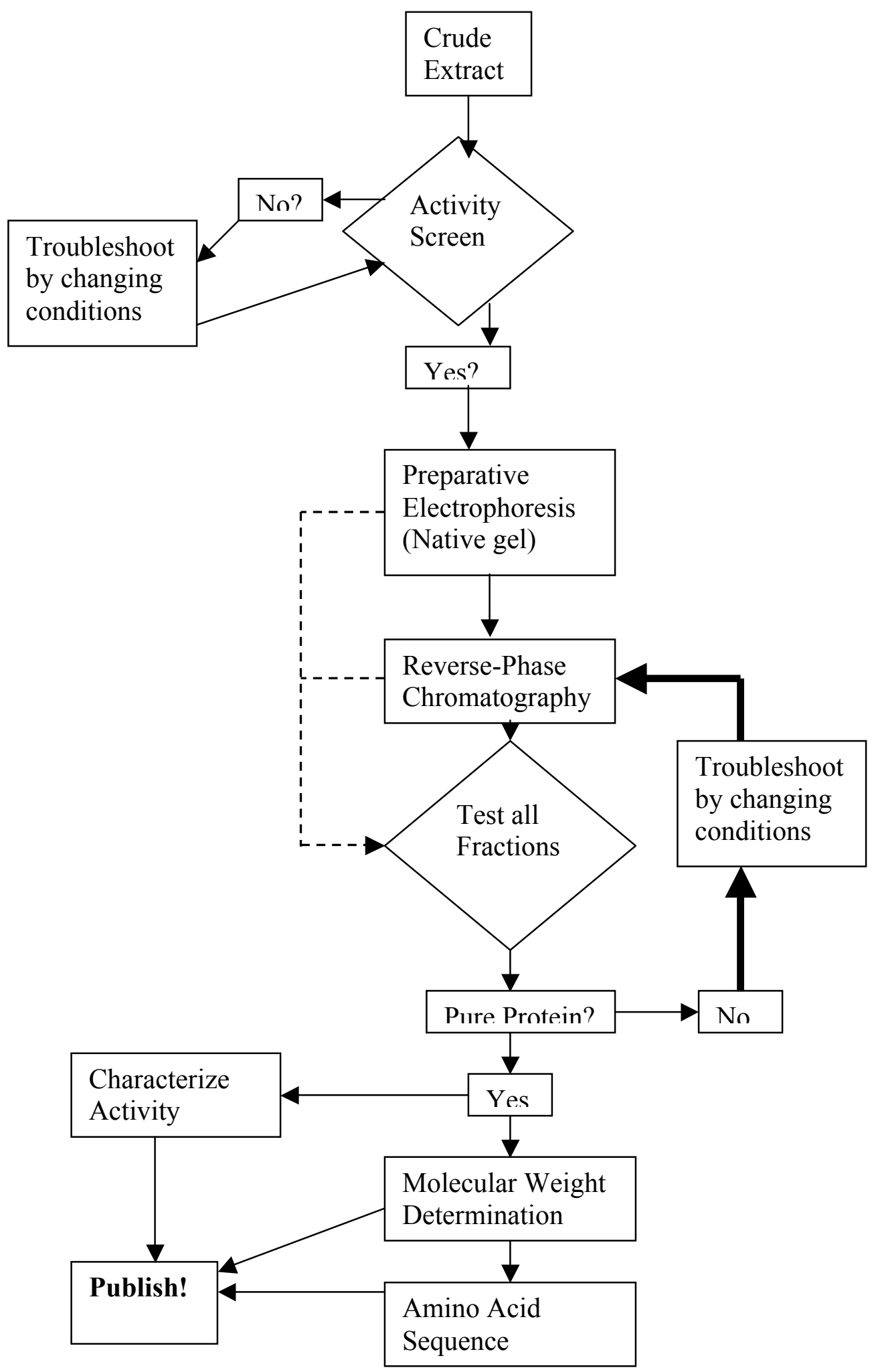




\section{Detailed Methods}

\section{Maintenance of Animals}

Swiftia exserta colonies were collected off Southeast Florida at depths of approximately 20-30 meters by Dr. Henry Feddern. Whole colonies were maintained in 550 gallon closed system aquaria with sub-gravel filters, activated charcoal filtration, and protein skimmers. Care was taken to avoid contact among colonies. Over the course of this study 50 to 75 colonies were sacrificed. The animals were fed two-day old Artemia nauplii (San Francisco Bay Brand) three times per week (Salter-Cid \& Bigger 1991). Temperatures ranged from $18-22^{\circ} \mathrm{C}$.

\section{Protein Purification Methods:}

\section{1) Tissue Extractions}

Fifty to seventy four to five centimeter branches from three or four whole colonies were first cut and stored at $-80^{\circ} \mathrm{C}$ until used. Frozen branchlets were submerged in an aqueous solution containing either 5\% acetic acid (Lee et al. 1997), 5\% acetic acid and 5M urea (Tincu et al. 2003), or 5\% acetic acid, 5M urea and 20\% acetonitrile (Schröder, 2010). These were then sonicated at 50 watts for three $60 \mathrm{sec}$ bursts on ice. After the central skeleton remains were removed the resultant slurry was stirred overnight on a magnetic stirplate (how else?) at $4^{\circ} \mathrm{C}$, clarified by high-speed centrifugation for 45 minutes at $10,000 \mathrm{xg}$, and stored at $-20^{\circ} \mathrm{C}$ in $1 \mathrm{ml}$ aliquots until further need.

\section{2) Preparative Electrophoresis}

Thawed $1 \mathrm{ml}$ aliquots were mixed with $0.5 \mathrm{ml}$ of Acid-Urea (AU) PAGE sample buffer [ $8 \mathrm{M}$ urea, $5 \%$ acetic acid, methyl green] and loaded onto a $10 \mathrm{~cm}$ tall preparative 
AU PAGE in a Bio-Rad 491 Preparative Electrophoresis cell. Gel consistency was 5\% acetic acid, $5 \mathrm{M}$ urea, $12.5 \%$ acrylamide-bisacrylamide. A constant voltage of $240 \mathrm{~V}$ was applied. Eluants were collected in 5\% acetic acid via a peristaltic pump and 20 minute fractions were collected (approx $6 \mathrm{ml}$ each). Acrylamide (Life Technologies, cat\# 15512023) and bis-acrylamide (Life Technologies, cat\# 15516-024) were of highest grade purity from Gibco BRL (Life Science, Grand Island, NY), electrophoresis grade TEMED (Pierce cat\# 17919) from Thermo-Pierce (Rockford, IL), and ammonium persulfate (Sigma cat\# A3678) purchased from Sigma (St. Louis, MO).

The collected fractions were lyophilized to dryness by centrifugal evaporation in a Savant 200 centrifuge and Savant 4104 cold trap (Kokryakov et al. 1993, Lee et al. 1997).

\section{3) Reverse-phase HPLC}

Five hundred $\mu l$ aliquots of Schröder-style extracts were injected onto a HAISIL 300 C18 column (model \# HS-2546-W185, Higgins Analytical, Mountain View, CA) and eluted with a linear $1 \%$ per minute gradient to $60 \%$ acetonitrile. $0.1 \%(\mathrm{v} / \mathrm{v})$ trifluoroacetic acid (TFA) was used as ion-pairing agent. HPLC grade water (W5-4) and acetonitrile (A9984) were purchased from Thermo-Fisher, sequanal grade TFA (85183) from Thermo-Pierce. The collected fractions were lyophilized to dryness by centrifugal evaporation in a Savant 200 centrifuge and Savant 4104 cold trap (Kokryakov et al. 1993, Lee et al. 1997).

\section{4) Analytical Electrophoresis}

Sodium dodecyl sulfate-tricine polyacrylamide gel electrophoresis (SDS-PAGE, Schägger and von Jagow, 1987) and Acid-Urea PAGE (Panyim and Chalkey, 1969) was 
performed using $12.5 \%$ acrylamide gels throughout to assess purification and approximate molecular weight of the active peptides. Enhanced silver staining for increased sensitivity in detecting protein bands was used to visualize proteins (Wray et al, 1981).

\section{5) Protein concentration determination}

The enhanced method was used with Pierce Chemicals commercial Bicinchoninnic acid (BCA) assay (Pierce, Rockford, IL, cat \# 23225). Bovine serum albumin, supplied with the kit at $1.0 \mathrm{mg} / \mathrm{ml}$ was used to establish s standard curve. The concentrations used for the curve are (in $\mu \mathrm{g} / \mathrm{ml}$ ): $250,200,150,100,50$, and $25 \mu \mathrm{g} / \mathrm{ml}$. Each crude extract was measured in triplicate, by adding $30 \mu \mathrm{l}$ of crude extract to $600 \mu \mathrm{l}$ of freshly prepared working solution and incubating this mixture for 60 minutes at $60^{\circ} \mathrm{C}$ in borosilicate glass tubes. The appropriate extraction buffer and the diluent for the standard were used (both sets in triplicate) as blanks for the extracts and the standard curve, respectively. After cooling the reaction mixture, the liquid was transferred to cuvettes and the absorbance at 562nm was recorded on a Beckman DU-730 spectrophotometer (Beckman Coulter, Brea, CA).

\section{Antimicrobial Testing:}

\section{1) Bacteria and Culture conditions}

Four test strains were graciously provided by: Dr. Alexander Cole (UCF), Dr. Tomas Ganz (UCLA), and Dr. Robert I. Lehrer (UCLA). All four bacteria were maintained on trypticase soy agar plates, two Gram-negative bacteria, Escherichia coli ML-35p and Pseudomonas aeruginosa H-103, and two Gram-positive bacteria, 
Staphylococcus aureus 930918-3 and Listeria monocytogenes EGD. E. coli ML-35p plates contained $100 \mu \mathrm{g} / \mathrm{ml}$ ampicillin to maintain selection for the plasmid carrying periplasmic beta-lactamase (Lehrer, et al., 1988). Mid-log phase bacteria were obtained 3 hours after seeding $50 \mathrm{ml}$ of trypticase soy broth (TSB) with $100 \mu \mathrm{l}$ of an overnight (stationary phase) culture of bacteria suspension. The overnight suspension was prepared by inoculating $50 \mathrm{ml}$ of TSB with bacteria from their respective agar plates. All bacteria were cultured at $37^{\circ} \mathrm{C}$, while bacteria solutions were also aerated in a shaker-incubator.

\section{2) Gel Overlay Assay}

Proteins in crude extracts were separated by electrophoresis on Acetic acid-Urea (AU) PAGE slab gels (Schägger and von Jagow, 1987). $20 \mu$ of crude extract was mixed with $10 \mu \mathrm{l}$ of sample buffer [8M urea, $5 \%$ acetic acid, methyl green] and loaded onto $10 \mathrm{~cm}$ AU-PAGE gels. The extracts were separated on 12.5\% acrylamide-bisacrylamide gels at $120 \mathrm{~V}$ (constant voltage) for 50 minutes with reverse polarity allowing the positively charged proteins to migrate into, and through, the PAGE gel. After washing the PAGE gel two times with $10 \mathrm{mM}$ sodium phosphate buffer ( $\mathrm{pH}$ 6.5) for 10 minutes each, the PAGE gel was carefully overlayed (to avoid air bubbles) onto an agarose layer (10mM sodium phosphate $\mathrm{pH} 6.5,100 \mathrm{mM}$ sodium chloride, $0.1 \%(\mathrm{w} / \mathrm{v})$ trypticase soy broth, $1 \%$ low EEO type 1 agarose) seeded with $4 \times 10^{\wedge} 6$ colony-forming units of midlogarithmic growth phase bacteria for 3 hours at $37^{\circ} \mathrm{C}$. Following the three hour incubation the PAGE gel was removed and stained by standard methods with $1 \%$ formalin Coomassie Blue (as in: Lee, et al., 1997; Menzel, et al., 2002) 


\section{3) Radial Diffusion Assay}

Every fraction from preparative electrophoresis was resuspended in $200 \mu 10.01 \%$ acetic acid, every fraction from RP-HPLC was resuspended in $100 \mu 10.01 \%$ acetic acid, and $7 \mu \mathrm{l}$ of every from fraction was pipetted into individual wells for a two-stage radial diffusion assay (Steinberg and Lehrer, 1997, Lee et al., 1997; Schröder, 2010). During initial screens $5 \mu \mathrm{g}$ of synthetic Clavanin A-acid (Peptide 2.0, Chantilly, VA) was added to one well as a positive control while $0.01 \%$ acetic acid was used as the vehicle control in another well of every plate. Every fraction collected during separation procedures was tested for antibacterial activity against the four test bacteria strains listed above while they were in mid-log growth phase.

\section{Mass spectrometry:}

\section{1) “Top Down" Protein Identification (Parent mass first, then fragment for internal sequence)}

Masses of purified active fractions from the Bio-Rad 491 Prep cell were initially screened on an Applied Biosytems/MDS Sciex Quadropole mass spectrometer. Single fractions were introduced by Electrospray Ionization (ESI) from a reverse phase $\mu \mathrm{HPLC}$ operating a linear $1 \%$ per minute gradient from $10 \%$ to $80 \%$ acetonitrile with $1 \%(\mathrm{v} / \mathrm{v})$ formic acid as ion-pairing agent. A splitter valve was employed to divert approximately $50 \%$ of the flow into fractions collected for one minute periods.

Fractions that contained protein were then applied to a Bruker SolariX-hybrid Qq-FTMS equipped with a 15 Tesla magnet system by ESI for accurate mass determination. 


\section{“Bottom-Up” Protein Identification (Fragment for internal sequence, then reconstruct parent ion)}

An Agilent QTOF was used to obtain internal amino acid sequence information from in-solution trypsin digested of the purified antibacterial peptide. In brief, peptides quantified on a NanoDrop were lyophilized, resuspended in digestion buffer, trypsin (sequencing grade) was added in the ratio 1:50 trypsin to peptide molecules, and digested at $37^{\circ} \mathrm{C}$ for 4 hours. Digested samples were desalted using a homemade $\mathrm{C} 18$ zip-tip, then loaded onto a $\mathrm{C} 18$ column, eluted with a gradient running from $10 \%$ acetonitrile to $40 \%$ acetonitrile over 65 minutes, and introduced into the QTOF by ESI. Every fifth spectrum of precursor ions ( $250 \mu$ s per spectrum) was subjected to collision energy sufficient to fragment the parent ion. Fragment ion spectra were collected for $200 \mu \mathrm{s}$. MASCOT was used on the data from this "bottom-up" approach to analyze mass spectra and screen against the NCBI non-redundant proteins database to identify likely parent proteins.

A further, manual BLAST screening of the trypsin-fragments' assigned amino acid sequences was performed by filtering the NCBI non-redundant protein database with the keyword "antimicrobial" since the peptide has antimicrobial activity.

\section{RESULTS}

\section{Initial screening by 'Gel Overlay Assay'}

Crude aqueous extracts from Swiftia exserta branchlets showed antimicrobial activity in initial screens as two distinct bands on AU-PAGE (fig 1a) and a 'gel-overlay assay' (fig 1b). Each lane was loaded with $20-30 \mu \mathrm{g}$ of total protein. The protein pattern 
seen in figure 1 is highly characteristic of Swiftia exserta and very repeatable if the salt concentrations in the various extracts are taken into account (i.e., the extracts are diluted with $5 \%$ acetic acid until the inherent salt concentrations do not adversely effect the electrophoresis). During my attempts to purify more peptide more than 15 extracts were prepared and electrophoresed on AU-PAGE. Each protein band stained Coomassie

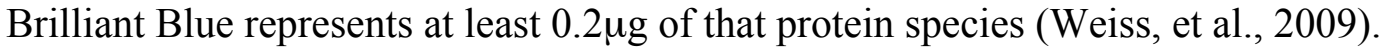

\section{Purifying and testing for antimicrobial proteins}

Each set of extracts of branchlets from three to four individual colonies were made in $70 \mathrm{ml}$ batches, and stored in $1 \mathrm{ml}$ aliquots at $-20^{\circ} \mathrm{C}$ before being separated by preparative electrophoresis (also AU-PAGE) to yield 95 fractions. More then 10 distinct extracts were made, tested, and fractionated. Protein concentrations, as determined by the enhanced bicinchoninic acid assay, in these extracts ranged from $1.8-4.7 \mathrm{mg} / \mathrm{ml}$. Testing antimicrobial activity of each of these 95 fractions with the 'radial diffusion assay' showed two fractions with activity against four bacteria: the Gram-positives $E$. coli ML-35p and P. aeruginosa H-103, and the Gram-negative $S$. aureus 930918-3 and L. monocytogenes EGD (fig. 2). The elution pattern shown in fig 2 is indicative of 5 preparative electrophoresis separation procedures. Since each set of fractions for a given electrophoretic separation are initiated manually the exact fraction number with the two active peptides shifted, but the pattern of late elution and a less active fraction followed by a more active fraction five to six fractions later was consistent between separations. 


\section{Assessing Purification by Alternate Electrophoresis Method and by Mass- \\ Spetrometry}

SDS-PAGE of the fraction with higher antimicrobial activity (the later fraction with greater activity, e.g. 76 in Fig 2), routinely exhibited electrophoretic mobility of approximately $15 \mathrm{kDa}$ under non-reducing conditions. Under reducing conditions (right lane of Fig 3) there is an additional smear between 4.5 and $5 \mathrm{kDa}$ along with the band at approximately $15 \mathrm{kDa}$ (fig. 3, middle lane). Crude extract is shown in the left lane for comparison, 20-30 $\mu \mathrm{g}$ of crude extract was loaded for that lane. Since Coomassie Brilliant Blue did not stain any bands in the center and right lanes (indicating that less than 50ng of protein is present), these bands are visualized with enhanced-sensitivity silver staining indicating that very low concentrations of proteins are present. Coomassie Brilliant Blue staining of protein bands in gels routinely detects $0.1 \mu \mathrm{g}$ of separated protein species, whereas enhanced silver staining can detect proteins present at less than lng (Weiss, et al., 2009). No protein concentration determination by BCA is possible at such low concentrations. The more active antibacterial fraction from the Bio-Rad 491 Prep Cell separation yields one mass peak on the Sciex quadrapole mass spectrometer. This isolated peptide demonstrated a mass range of 4695.67 Da by FT-MS. Figure 4 is a representative ion trace from FT-MS.

\section{Determining protein sequence via Mass-Spectrometry}

Peptide sequences obtained after trypsin digestion and assigned by manual BLAST search of the NCBI non-redundant protein database filtered for the keyword "antimicrobial" aligned to various beta-defensins, and other cathelicidin family members. 
Several of the sequences identified by mass spectrometry are aligned with two cathelicidins and the human alpha-defensin in Table 1. Current sequence information, however, limits a definitive identification of the most active antibacterial fraction's sequence and identity at this time.

\section{DISCUSSION}

Innate immunity, across multi-cellular animal phyla, depends heavily on antimicrobial peptides to control invading pathogens (Bulet et al. 2004). My goal was to discover, purify and characterize some of these peptides in our model organism, Swiftia exserta (Cnidaria, Anthozoa, Octocroallia, Alcyonaria). The lack of zooxanthellae in my animal model ensures that any characterized antibacterial activity is due to gene products of Swiftia and will, thus, allow further insight into the molecular evolution of these geneencoded host defense peptides/proteins. The conventions regarding the nomeclature for antimicrobial peptides are reviewed by Wang (2010), but essentially allow the investigator fairly free reign. The two main conventions take either the species and genus of origin or the relevant amino acids into consideration when naming the novel antimicrobial peptide. I thus propose to name the more active peptide discovered in this investigation swiftin in reference to the species of origin. In addition, logic dictates that the more active or abundant peptide be characterized first.

These peptides from the octocoral anthozoan Swiftia exserta complement the 2006 report on Aurelin (from Aurelia aurita in the class scyphozoa), the 2011 description of Damicornin from the hexacoral anthozoan Pocillopora damicornis, and the three antibacterials, arminin, periculin and hydramacin from Hydra ssp. to begin an 
understanding of the repertoire of antibacterial peptides in cnidaria. Further characterization of the antibacterial proteins found in Swiftia exserta (and other cnidaria, animals that diverged before the protostome-deuterostome split) will further our understanding of the evolution of this crucial aspect of innate immunity.

Initial screening for antibacterial activity shows the existence of two relatively abundant antibacterial peptides with strong antibacterial activity from whole aqueous extracts of Swiftia exserta (fig 1a and 1b). The strongly staining protein bands visible in fig 1a indicate that antimicrobial peptides make up approximately $5-10 \%$ of the total proteins extracted. However, once purified, there is not enough protein in the active fractions to perform the chemical protein concentration determination by bicinchonninc acid (BCA), enhanced silver staining indicates that only approximately 5-10ng survive this purification procedure (a loss of more than 97\%).

Further characterization of the most-active peptide, with a mass of 4698 Dalton coupled with the approximately $15 \mathrm{kDa}$ bands on SDS-PAGE indicates the likely presence of an antimicrobial peptide from the cathelicidin family. Cathelicidins are translated as $15-18 \mathrm{kDa}$ prepropeptides and are processed to release an active antimicrobial peptide with a mass range of 4-6 $\mathrm{kDa}$ (Zanetti, 2005). The human cathelicidin, LL-37, was initially discovered in the $18 \mathrm{kDa}$ preproform and described as hCAP18 (human Cathelicidin Antimicrobial Peptide of $18 \mathrm{kDa}$ ) by Agerberth, et al., (1995) and Cowland, et al., (1995). Follow-up on these exciting indications could yield the first cathelicidin antimicrobial peptide found in invertebrates. Fragments of internal sequence align with the preproprotein region of both the human cathelicidin, hCAP18, 
and with the hagfish cathelicidin, hematopoetic antimicrobial peptide 37 (table 1)

supporting the hypothesis that swiftin is an ancestral cathelicidin.

Data analysis of the FT-MS dataset would have been performed had an appropriate, manually created, database been available to screen against. Time constraints during my research trip to the UCLA Passarow Mass Spectrometry facility (directed by Dr. Kym Faull) interfered with creating this database, and technical difficulties interfered with transferring the NCBI non-redundant protein database for use; however, the data is available for future use if such a database were to be created.

Utilizing the amino acid sequences of the various mass spectrometry derived peptide fragment to screen Swiftia exserta mRNA will allow future phylogenetic analysis and provide evolutionary insights into the origins of immune systems. Determining the mRNA sequence by using degenerate primers with 5-prime and 3-prime Rapid Amplificatino of cDNA Ends (RACE) will provide the complete cDNA and thus the amino acid sequence of the complete protein. Further use of molecular biology techniques will determine the gene structure and chromosomal location. In addition, a synthetic peptide can be used to determine the secondary and tertiary structure of swiftin, provide sufficient peptide to establish a Minimal Inhibitory Concentration (MIC), and test the optimal conditions for antimicrobial activity. Having both the cDNA and synthetic peptide will allow the determination of expression patterns (both transcription via riboprobes and translation with antibodies to synthetic peptide) in naïve and immunochallenged animals. In addition, a synthetically produced swiftin can be used to confirm the mechanism by which swiftin kills microbes. The general mechanism used by most antimicrobial peptides is to assemble into oligomeric pores in the target's plasma 
membrane causing osmotic imbalance and eventual rupture of the target cell (Bolintineanu, et al., 2010).

Discovering these more divergent antibacterial peptides/proteins is also of obvious potential clinical interest since many human pathogens are developing resistance to traditional antibiotics. A better understanding of the defense mechanisms of anthozoa will be of great benefit in the on-going efforts to preserve the rich biodiversity of coral reefs that are currently in precipitous decline world-wide, in part due to widespread disease problems. 
Flow chart for future investigations:

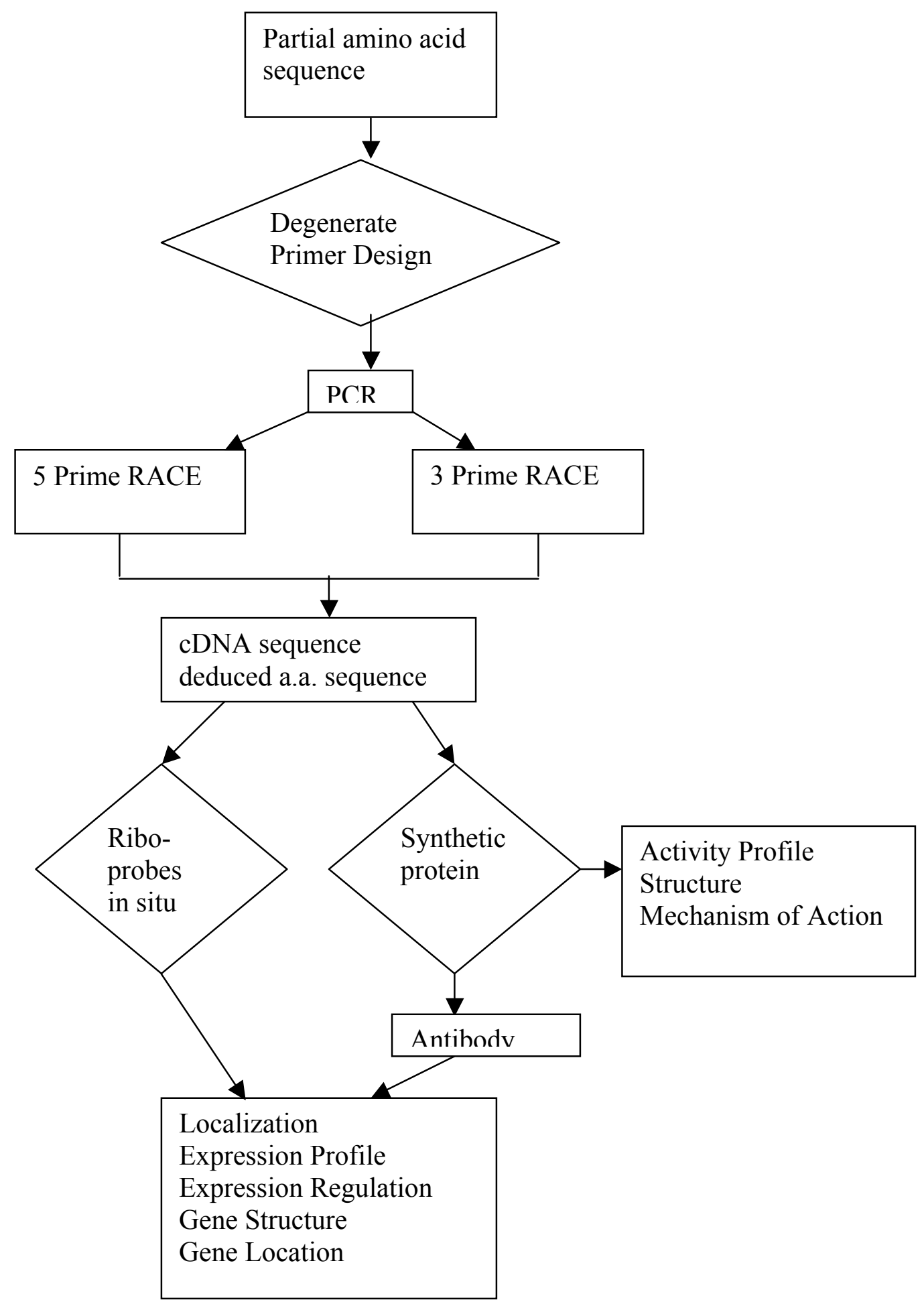




\section{ACKNOWLEDGMENTS}

I thank Tomas Ganz for invaluable assistance with HPLC hardware configuration; Sylvia Harwig, In-Hee Lee, and Robert Lehrer for their patience and for scientific insights; and eBay for facilitating lab equipment purchases; and Kym Faull for allowing me to visit the Passarow Mass Spectrometry Facility at UCLA and have unrestricted access to the instruments there.

Test bacteria [E. coli ML-35p, S. aureus 930918-3, L. monocytogenes EGD, and $P$. aeruginosa $\mathrm{H}-103$ ] were provided by Robert Lehrer, Tomas Ganz, and Alexander Cole. Support provided by NIH/NIGMS grant R25 GM061347 as a subproject award to LPM.

\section{REFERENCES}

Agerberth, B., Gunne, H., Oderberg, J., Kogner, P., Boman, H., ang G. Gudmundsson. 1995. FALL-39, a putative human peptide antibiotic, is cystein-free and expressed in bone marrow and testis. Proc. Nat. Acad. Sci. USA. 92:1995-199.

Augustin, R., Anton-Erxleben, F., Jungnickel, S., Hemmrich, G., Spudy, B., Podschun, R., and T.C.G. Bosch. 2009. Activity of the novel peptide Arminin against multiresistant human pathogens shows the considerable potential of phylogenetically ancient organisms as drug sources. Antimicrob. Agents Chemother. 53:5245-5250.

Augustin, R., and T.C.G. Bosch. 2010. Cnidarian immunity: a tale of two barriers. Adv. Exp. Med. Biol. 708:1-16.

Battison, A.L., Summerfield, R., and A. Patrzykat. 2008. Isolation and characterization of two antimicrobial peptides from the haemocytes of the American lobster Homarus americanus. Fish Shellfish Immunol. 25:181-187.

Bolintineanu, D., Hazrati, E., Davis, H.T., Lehrer, R.I., and Y. Kaznessis. 2010 Antimicrobial mechanism of pore-forming protegrin peptides: 100 pores to kill E. coli. Peptides. 31:1-8. 
Brück, T.B., Brück, W.M., Santiago-Vázquez. L.Z., McCarthy, P.J., and R.G.Kerr. 2007. Diversity of the bacterial communites associated with the azooxanthellate deep water octocorals Leptogorgia minimata, Iciligorgia schrammi, and Swiftia exserta. Mar. Biotech. (NY). 9(5):561-576.

Bulet P., Stöcklin R., and L. Menin. 2004. Anti-microbial peptides: from invertebrates to vertebrates. Immunol. Rev. 198:169-184.

Burkholder, P.R. and L.M. Burkholder. 1958. Antimicrobial activity of horny corals. Science 127(3307):1174-1175.

Charlet, M., Chernysh, S., Phillipe, H., Hetru, C., Hoffmann, J.A., and P. Bulet. 1996. Innate immunity: isolation of several cysteine-rich antimicrobial peptides from the blood of a mollusk, Mytilus edulis. J. Biol. Chem. 271:21808-21813.

Chen, D., Yu, S., van Ofwegen, L., Proksch, P., and W. Lin. 2011.Anthogorgienes A-O, new guaiazulene-derived terpenoids from a Chinese gorgonian Anthogorgia species, and their antifouling and antibiotic activities. J. Agric. Food Chem. 60(1):112-123.

Cowland, J.B., Johnson, A.H., and N. Borregard. 1995. hCAP-18, a cathelin/probactenicin-like protein of human neutrophil specific granules. FEBS Lett. 368:173-176.

Cuthbertson, B.J., Deterding, L.J., Williams, J.G., Tomer, K.B., Etienne, K., Blackshear, P.J., Büllesbach, E.E., and P.S. Gross. 2008. Diversity of penaeidin antimicrobial peptide form and function. Dev. Comp. Immunol. 23(3):167-181.

Destoumieux, D., Bulet, P., Loew, D., van Dorsselaer, A., Rodriguez, J., and E. Bachère. 1997. Penaeidins, a new familiy of antimicrobial peptides isolated from the shrimp Penaeus vannameii (Decaapoda). J. Biol. Chem. 272:28398-28406.

Dolashka, P., Moshtanska, V, Borisova, V., Dolashki, A., Stevanovic, S., Dimanov, T., and W. Voelter. 2011. Antimicrobial proline-rich peptides from the hemolymph of marine snail Rapana venosa. Peptides. 32:1477-1483. 
Ellis J., and D. Solander. 1786. The Natural history of many curious and uncommon Zoophytes: Collected from various parts of the globe. London, Benjamin White \& Son.

Fedders, H., Michalek, M., Grötzinger, J., and M. Leippe. 2008. An exceptionally salttolerant antimicrobial peptide derived from a novel gene family of the haemocytes of the marine invertebrate Ciona intestinalis. Biochem. J. 416:65-75.

Galinier, R., Roger, E., Sautiere, P-E, Aumelas, A., Banaigs, B., and G. Mitta. 2008. Halocyntin and paillosin, two new antimicrobial peptides isolated from hemocytes of the solitary tunicate, Halocynthia papillosa. J. Pept. Sci. 15:48-55.

Gennaro, R., and M. Zanetti. 2000. Structural features and biological activities of the cathelicidin-derived antimicrobial peptides. Biopolymers. 55:31-49.

Gudmundsson, G.H., Agerberth, B., Odeberg, J., Bergman, T., Olsson, B., and R. Salcedo. 1996. The human gene FALL39 and processing of the cathelin precursor to the antibacterial peptide LL-37 in granulocytes. Eur. J. Biochem. 238(2):325-332.

Iijima, R., Kisugi, J., and M. Yamazaki. 2003. A novel antimicrobial peptide from the sea hare Dolabella auricularia. Dev. Comp. Immunol. 27:305-311.

Jang, W.S., Kim, K.N, Lee, Y.S., Nam M.H, and I.H. Lee. 2002. Halocidin: a new antimicrobial peptide from hemocytes of the solitary tunicate, Halocynthia aurantim. FEBS Lett. 521:81-86.

Kokryakov, V.N., Harwig, S.S., Panyutich, E.E, Shevchenko, A.A., Aleshina, G.M., Shamova, O.V., Korneca, H.A. and R.I. Lehrer. 1993. Protegrins: leukocyte antimicrobial peptides that combine features of corticstatic defensins and tachyplesins. FEBS Lett. 327(2):231-236.

Larrick, J.W., Hirata, M., Zhong, J., and S.C. Wright. 1995. Anti-microbial activity of human CAP18 peptides. Immunotechnology. 1:65-72.

Lee, I.-H., Zhao, C., Cho, Y., Harwig, S.S., Cooper, E.L., and R.I. Lehrer. 1997a. Clavanins, alpha-helical antimicrobial peptides from tunicate hemocytes. FEBS Lett. 400(2):158-162. 
Lee, I.H., Cho, Y., and R.I. Lehrer, 1997b. Styelins, broad-spectrum antimicrobial peptides from the solitary tunicate, Styela clava. Comp. Biochem. Physiol. B. Biochem. Mol. Biol. 118(3):515-521.

Lee, I.H., Lee, Y.S., Kim, C.H., Kim, C.R., Hong, T., Menzel, L., Boo, L.M., Pohl, J., Sherman, M.A., Waring, A., and R.I. Lehrer. 2001. Dicynthaurin: an antimicrobial peptide from hemocytes of the solitary tunicate, Halocynthia aurantium. Biochim. Biophys. Acta, 1527:141-148.

Lehrer, R.I., Barton, A., and T. Ganz. 1988. Concurrent assessment of inner and outer membrane permabilization and bacteriolysis in E. coli by multiple wavelength spectrophotometry. J. Immunol. Meth. 108(1-2):153-158.

Lehrer, R.I., Tincu, A.J., Taylor, S.W., Menzel, L.P., and A.J. Waring. 2003. Natural peptide antibiotics from tunicates: structures, functions and potential uses. Integr. Comp. Biol. 43(2):313-322.

Li, C., Haug, T., Styrvold, O.B., Jørgensen, T.O., and K. Stensvåg. 2008. Strongylocins, novel antimicrobial peptides from the green sea urchin, Strongylocentrotus droebachiensis. Dev. Comp. Immunol. 32:1430-1440.

Li, C., Haug, T., Moe, M.K., Styrvold, O.B., and K. Stensvåg. 2010. Centrocins: isolation and characterization of novel dimeric antimicrobial peptides from the green sea urchin, Strongylocentrotus droebachiensis. Dev. Comp. Immunuol. 34:959-968.

Menzel, L., Lee, I-H., Sjostrand, B. and R.I. Lehrer. 2002. Immunolocalization of clavanins in Styela clava hemocytes. Dev. Comp. Immunol. 26: 505-515.

Meszaros, A., and C.H. Bigger. 2008. Qualitative and quantitative study of wound healing processes in the coelenterate, Plexaurella fusifera: spatial, temporal, and environmental (light attenutation) influences. J. Invert. Path. 73:321-331.

Miyata, T., Tokunaga, F., Yoneya, T., Yoshikawa, K., Iwanaga, S., Niwa, M., Takao, T., and Y. Shimonishi. 1989. Antimicrobial Peptides, Isolated from Horseshoe Crab Hemocytes, Tachyplesin II, and Polyphemusins I and II: Chemical Structures and Biological Activity. J. Biochem. 106(4):663-668. 
Nakamura, T., Furunaka, H., Miyata, T., Tukonaga, F., Muta, T., Iwanaga, S., Niwa, M., Takao, T., and Y. Shimonishi. 1988. Tachyplesin, a class of antimicrobial peptide from the hemocytes of the horsehsoe crab (Tachypleus tridentatus). Isolation and chemical structure. J. Biol. Chem. 263(32):16709-16713.

Olano, C.T., 1993. Cellular aspects of alloimmunity and other responses in the gorgonian Swiftia exserta. Thesis (M.S.) Florida International University.

Ovchinnikova, T.V., Balandin, S.V., Aleshina, G.M., Tagaev, A.A., Leonova, Y.F., Krasnodembsky, E.D., Men'shenin, A.V., and V.N. Kokryakov. 2006. Aurelin, a novel antimicrobial peptide from jellyfish Aurelia aurita with structural features of defensins and channel-blocking toxins. Biochem. Biophys. Res. Comm. 348(2):514-523.

Panyim, S., and R. Chalkey. 1969. High resolution acrylamide gel electrophoresis of histones. Arch. Biochem. Biophys. 130:337-346.

Saito, T., Kawabata, S., Shigenaga, T., Takayenoki, Y., Cho, J., Nakajima, H., Hirata, M., and S. Iwanaga. 1995. A novel big defensin identified in horseshoe crab hemocytes: isolation, amino acid sequence, and antibacterial activity. J. Biochem. 117(5):1131-1137.

Schägger, H., and G. von Jagow. 1987. Tricine-sodium dodecyl sulfate-polyacrylamide gel electrophoresis for the separation of proteins in the range from 1 to $100 \mathrm{kDa}$. Anal. Biochem. 166:368-379.

Schmitt, P., Rosa, R.D., Duperthuy, M., de Lorgeril, J., Bachère, E., and D. Destoumieux-Garzon. 2012. The antimicrobial defense of the pacific oyster, Crassostrea gigas. How diversity may compensate for scarcity in the regulation of resident/pathogenic microflora. Front. Microbiol. 3:160.

Schröder, J.-M. 2010. Purifying antimicrobial peptides from human skin. Methods Mol. Biol. 618:15-30.

Segura, A., Morenao, M., Molina, A., and F. Garcia-Olmedo. 1998. Novel defensin subfamily from spinach (Spinacia oleracea). FEBS Lett. 435:159-162. 
Sperstad, S.V., Haug, T., Paulsen, V., Rode, T.M., Strandskog, G., Solem, S.T., Styrvold, O.B., and K. Stensvåg. 2009a. Characterization of crustins from the hemocytes of the spider carb, Hyas araneus, and the red king crab, Paralithodes canthschaticus. Dev. Comp. Immunol. 33(4):583-591.

Sperstad, S.V., Haug, T., Vasskog, T., and K. Stensvåg. 2009b. Hyastatin, a glycine-rich multi-domain antimicrobial peptide isolated from the spider crab, (Hyas araneus) hemocytes. Mol. Immunol. 46:2604-2612.

Steinberg, D.A. and R. I. Lehrer. 1997. Designer assays for antimicrobial peptides. Disputing the "one-size-fits-all" theory. Methods Mol. Biol. 78:169-186.

Stensvåg, K., Haug, T., Sperstad, S.V., Rekdal, Ø., Inddrevoll, B., and O.B. Styrvold. 2008. Arasin 1, a proline-arginine-rich antimicrobial peptide isolated from the spider crab, Hyas araneus. Dev. Comp. Immunol. 32:275-285.

Tincu, J.A., Menzel, L.P. Azimov, R., Sands, J., Hong, T., Waring, A.J., Taylor, S.W., and R.I. Lehrer. 2003. Plicatamide, an antimicrobial octapeptide from Styela plicata hemocytes. J. Biol. Chem. 278(15):13546-13553.

Uzzell, T., Stolzenberg, E.D., Shinnar, A.E., and M. Zasloff. 2003. Hagfish intestinal antimicrobial peptides are ancient cathelicidins. Peptides. 24:1655-1667.

Vidal-Dupiol, J., Ladière, O., Destoumieux-Garzón, D., Sautière, P.-E., Meisterzheim, A.-L., Tambutté, E., Tambutté, S., Duval, D., Fouré, L., Adjerour, M., and G. Mitta. 2011. Innate immune responses of a scleractinian coral to vibriosis. J. Biol. Chem. 286:22688-22698.

Wang, G. 2010. Antimicrobial peptides: Discovery, design and novel therapeutic strategies. Adv. Mol. Cell. Biol. Vol. 18. CABI. England.

Wang, J., Wong, E.S.W., Whitley, J.C., Li, J., Stringer, J.M., Short, K.R., Renfree. M.B., Belov, K., and B.G. Cocks. 2011. Ancient antimicrobial peptides kill antibiotic-resistant pathogens: Australian mammals provide new options. PLoS One. 6(8):e24030.

Weiss, W., Weiland, F., and A. Görg. 2009. Protein detection and quantitation technologies for gel-based proteome analysis. Meth. Molec. Biol. 564:59-82. 
Wray, W., Boulikas, T., Wray, V.P. and R. Hancock. 1981. Silver staining of proteins in polyacrylamide gels. Anal. Biochem. 118(1):197-203.

Zanetti, M. 2005. The role of cathelicidins in the innate host defense of mammals. Curr. Issues. Mol. Biol. 7(2):179-196. 


\section{APPENDIX III}

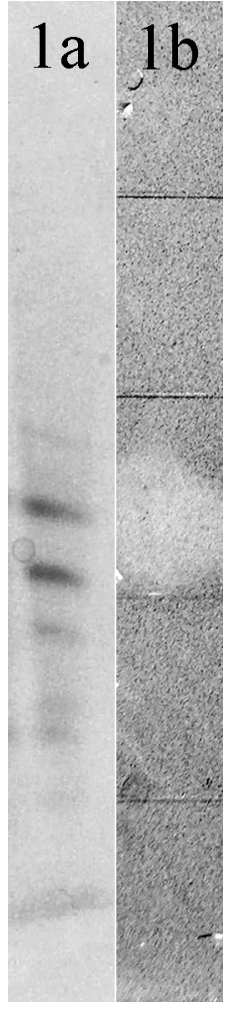

Figures 1a and 1b. Initial screening for antibacterial ativity. Fig 1a. AU-PAGE of Swiftia exserta extract.

Fig.2 Extracts electrophoresed on AU-PAGR as in Fig 1. After washing two times with $10 \mathrm{mM}$ sodium phosphate buffer $\mathrm{pH} 7.2$, the gel was overlayed onto a nutrient poor agar ( $1 \%$ agar, $0.3 \%$ trypticase soy broth, $10 \mathrm{mM}$ sodium phosphate buffer $\mathrm{pH} 7.2,100 \mathrm{mM}$ sodium chloride) seeded with $4 \times 10^{\wedge} 6$ Staphylococcus aureus colony forming units (CFU), and incubated at $37 \mathrm{C}$ for three hours. Following the incubation the gel was removed and replaced with a nutrient rich top agar (6\% trypticase soy broth, $1 \%$ agarose, $10 \mathrm{mM}$ sodium phosphate buffer $\mathrm{pH} 7.2,100 \mathrm{mM}$ sodium chloride). The plate was then incubated at $37 \mathrm{C}$ overnight to allow colony formation. Clear zones in Fig 2 correlate with the Coomassie stained band in the AU-PAGE shown in Fig 1. 
Typical Radial Diffusion Assay of Preparative Electrophoresis Fractions

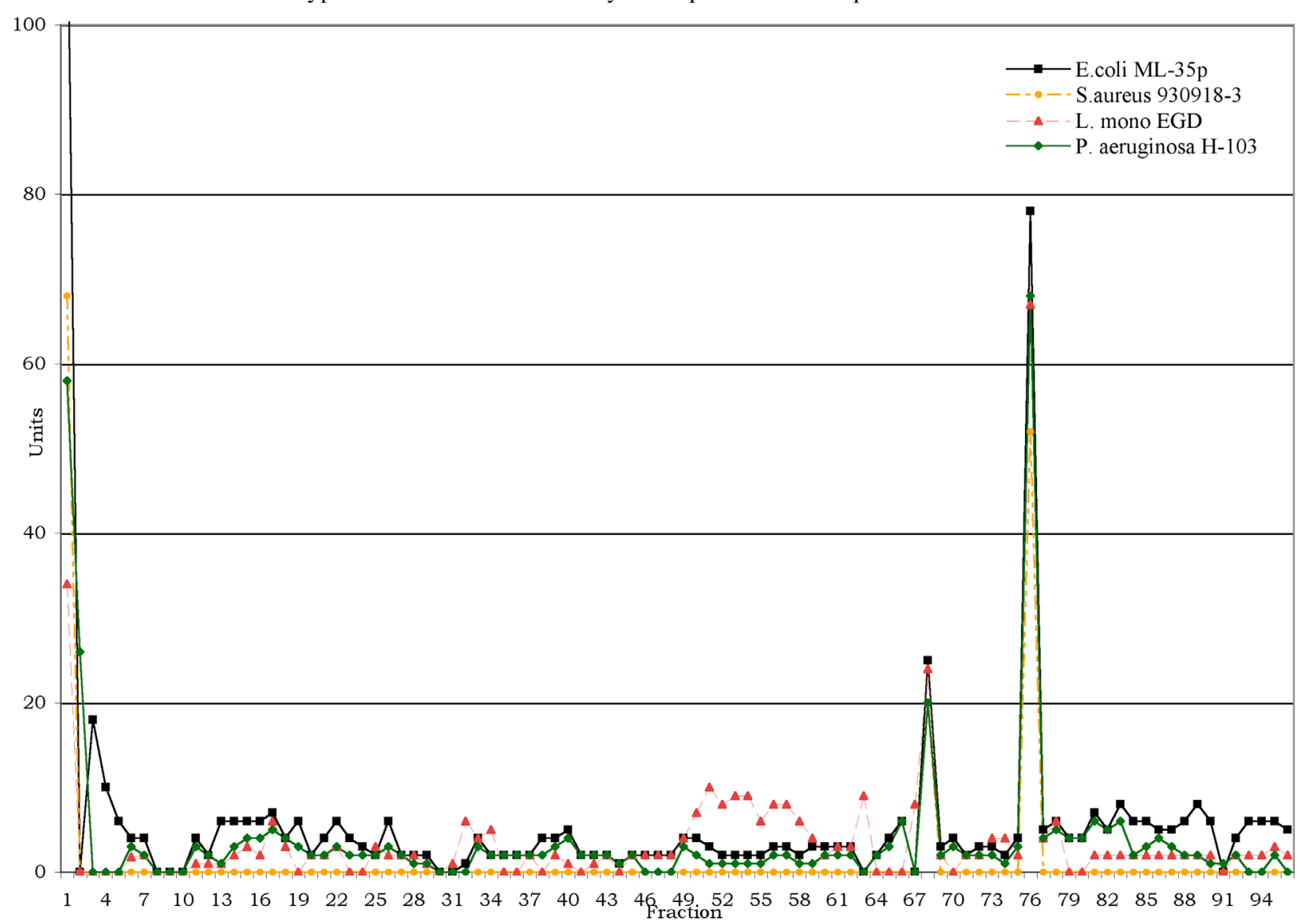

Figure 2. A representative graph of typical antibacterial activity as measured with the radial diffusion assay. Zone of clearance units are measured in $1 / 10^{\text {th }}$ millimeter. Fractions were collected from a Bio-Rad 491 prep cell, concentrated 100-fold by

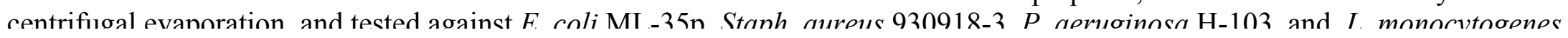




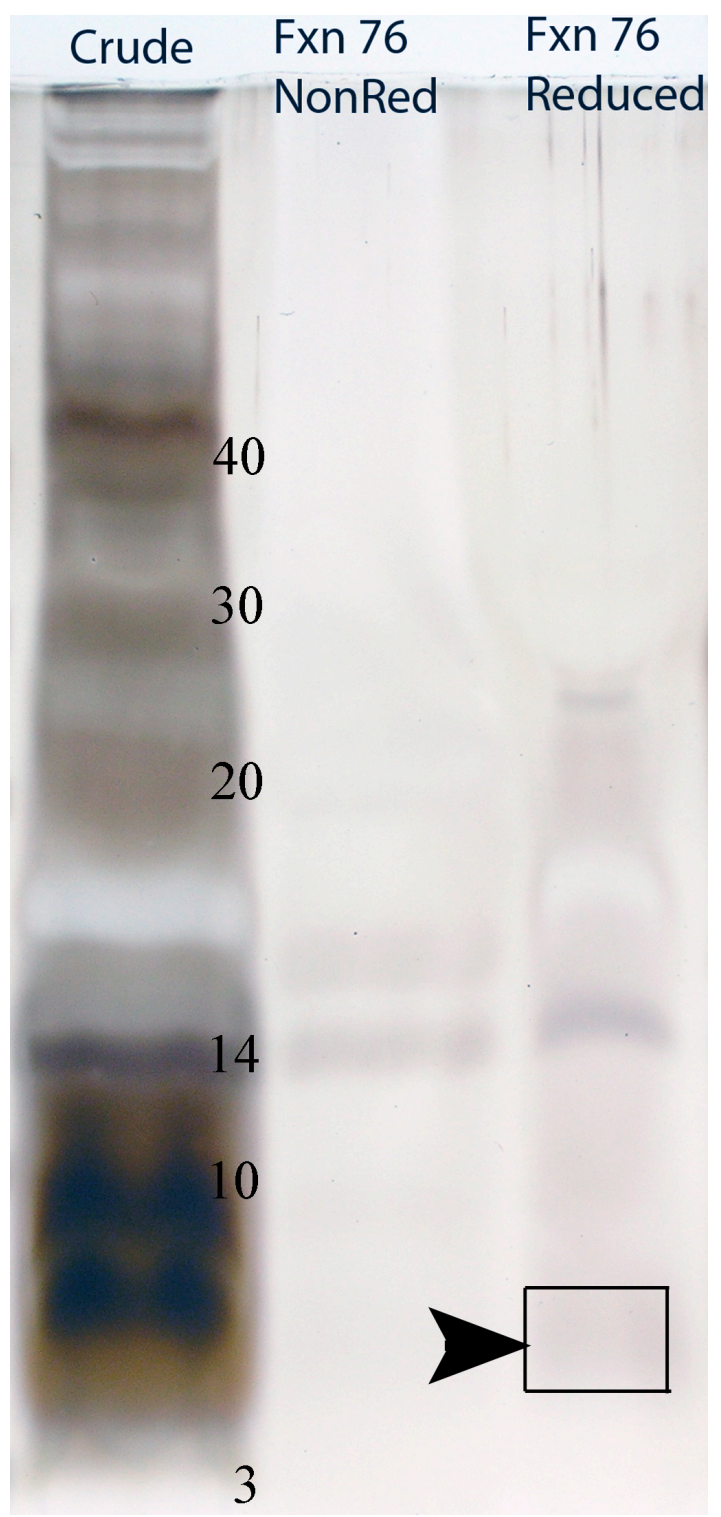

Figure 3. A 10\% acrylamide PAGE formalin silver stained. Lanes contain, from left to right: $20-30 \mathrm{mg}$ crude extract not reduced, fraction 76 from the figure 3 (higher activity) not reduced, and (same) fraction 76 reduced with 2-mercaptoethanol. The more active antibacterial fraction migrates at approximately $5 \mathrm{kDa}$ in the right lane. Molecular weights are indicated to the right of the crude extract. 
\#61415 AV: 443 IT: 500.000 ST: 0.98 uS: 1 CS: 4 AMW: 4695.67 NL: $9.67 E 2$ F: FTMS + p NSI Full ms [800.00-2000.00]

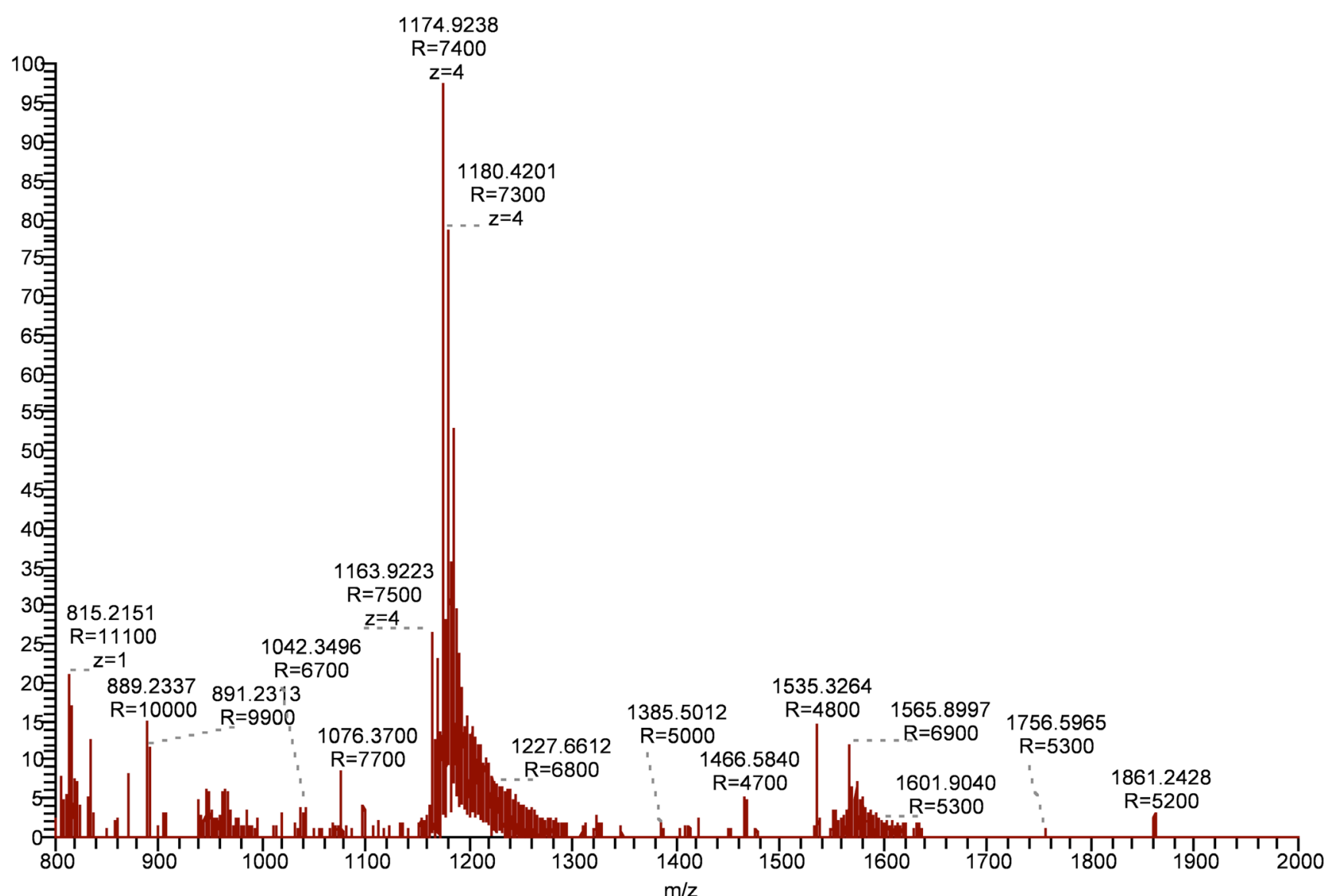

Figure 4. FT-MS $\mathrm{m} / \mathrm{z}$ trace showing the major ion peak from fraction 76 (same as from figure 3 and figure 4). $1174.9238 \mathrm{~m} / \mathrm{z}$ is the protonated +4 charge state of the molecular ion $[\mathrm{M}+] 4698.67$. 
Table 1

Alignment of Swiftin fragments to hCAP PreProProtein (without active antimicrobial peptide)

KQR---SVGPYPIAFLLFDLDLFK KNAIMAILIGLGLIFAFRFSQK CYVDDL RTGSTN CDLPMVLL

hCAP18 1 MGTMKTQRDGHSLGRWSLVLLLLGL-------VMPLAI-IAQVLSYKEAVL RAIDGI NQRSSD ANL--YRL 61

fragments LDLEPAK------GSGSTY SLTLSSPK C------GPVRALQAWK

hCAP18 62 LDLDPRPTMDGDPDTPKPV SFTVKETV CPRTTQQSPEDCDFKKD 107

fragments GVIQTHVGLFFASIIFSLLHIR CSQICVNTK--

hCAP18 108 GLVKRCMGTVTLNQARGSFDIS CDKD--NKRFA 136

\begin{tabular}{|c|c|c|c|c|c|c|}
\hline Descr. & Max score & Total score & Query cover & E-value & Ident & Accession \\
\hline protein & 15.3 & 15.3 & $26 \%$ & 0.39 & $23 \%$ & 40111 \\
\hline
\end{tabular}

Query MAILIGLGLIFAFRF SQKCYVDDLRTGSTNCDLPMVL LLDLEP
$\mathrm{M}+\mathrm{I}++++++\quad+\mathrm{D}+\mathrm{S}+++\mathrm{L} \quad \mathrm{LLDL}+\mathrm{P}$

Sbjet 27 MPLAI-IAQVLSYKEAVLRAIDG INQR SSDANL_YR LLDLDP 66

Alignment of Swiftin fragments to hCAP active antimicrobial peptide - LL-37

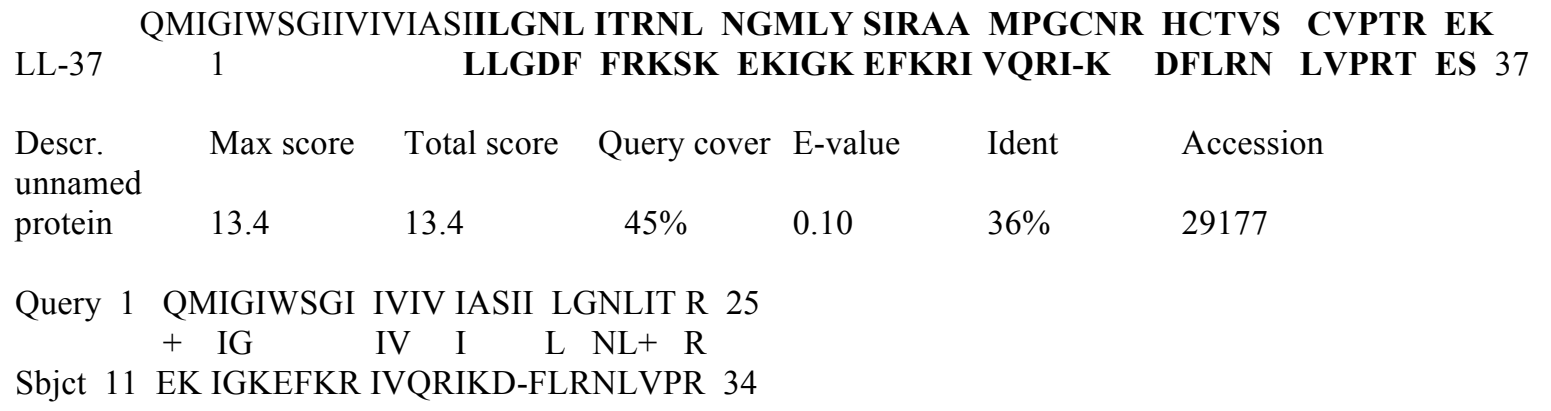


Alignment of Swiftin fragments to Hagfish PreProProtein (without active antimicrobial peptide) KVDCANLSSPWKPLLLILPMR CAASS

1 MKSLCVPAVLSLVLI LLLDQ 20

GAPGALPRPGVSR QVVVEVTDQSGKPIR KQLLE----AVRENQLLIVVGDTGSGK

21 -APTARADDSLSK EQVENAVDEALDKLN KQQVSTRKLALSEQQ---- --DIQADE 68

\section{LHTEGHNVIGTSR VMASCLK ETGALHPR IAGAIKQR GNRTPVAN KGLDVTETFPK}

69 TDVEGQFTIKFDV VETEC-- --NADDPR DWADCPIA TDSTPV-D AQCEVTVLSTE 118

\section{DGL-INGVG C-FGSTTKSFRR YTLVRQAENQGR}

119 DSLDVGDAT CDFNRTDGNARR -- $\quad$--RRG 142

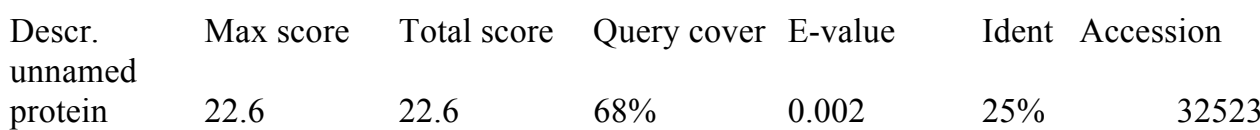

Query 46 APGA LPRPG VSRQ VVVEVT DQSGKP IRKQLL E AVRENQ LLIVVGDTG SGKLHT EGHNVIG

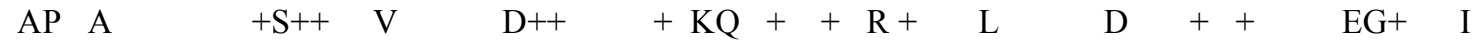

Sbjct 21 APTA RADDS LSKE QVENAV DEALDK LNKQQV-STRK-LA LSEQQ DIQ ADETDV EGQFTIK 78

Query 106 TSR VMAS CLKETGALH PRIAGAIKQRGNRTPVA NKGL DVTETFP KDGL-INGVGC - FGST
A PR
+ TPV +
$+\mathrm{VT}$
$+\mathrm{D} \mathrm{L}+$
$\begin{array}{lll}\mathrm{C} & \mathrm{F}\end{array}$

Sbjet 79 FDV VETE C- - - NADD PRDWADCPIATDSTPV - DAQC EVTVLST EDSLDVGDATCDFNR T 133

Query 164 TKSFRR

RR

Sbjct 134 DGNARR 139 
Alignment of Swiftin fragments to Hagfish active antimicrobial peptide - AMP37

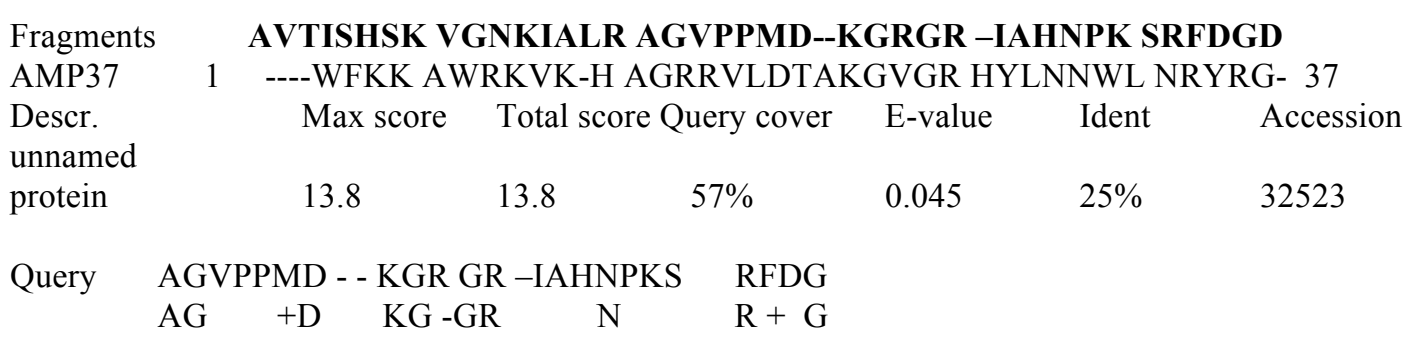

Sbjct 12 AGRRVLD TAKGVGR HYLNNWLN RYRG 37

Alignment of Swiftin fragments to human alpha-defensin-1 PreProProtein (without active antimicrobial peptide)

Fragments AVTISHSK VGNKIALR AGVPPMDKGRGR IAHNPK SRFDGD EWTNVSGGK VTVVLSPR TPPSESPR

HNP-1 MRTLAILA AILLVALQ AQAEPLQARADE VAAAPE QIAADI PEVVVSLAW -DESLAPK HPGSRKNM 64 


\section{Chapter 5}

\section{Conclusions}

While the work presented here is by no means an exhaustive study of the immune reactions in Swiftia exserta I have built a foundation to further our understanding of how Swiftia exserta, and other cnidaria, might defend themselves from invasion by non-self (pathogens or graft-like parabiosis). In the first chapter I set out to document the over-all architecture, anatomical arrangement of cells and their composition, and identify the cell populations present in the normal, non-stimulated, non-injected (Olano and Bigger, 2000), and non-reacting (Olano, 1993) animal to establish a basis for understanding the differences in stimulated (or reacting) animal. While this basic information may seem insignificant it is crucial for any further studies involving Swiftia exserta or similar cnidaria to have a baseline for "normal" morphology, cell types, and cell populations.

In the next chapter I examined the functional abilities of the coenenchyme cell types in the normal un-stimulated state. This new information now pairs the location of several key enzymes found in constitutive phagocytes with some of the previous results about phagocytic activity of stimulated cells (Olano and Bigger, 2000). With novel insight from these two chapters I can now propose a model for host defense in Swiftia exserta that may apply to other octocorals as well.

The schematic, figure 1, will help visualize this new model. In step one, or the general state for Swiftia exserta (and other animals), potential pathogens are kept out of the body by the integrity of the outer cell layer (fig. 1a). Inevitably, some potentially invasive micro-organisms will adhere to the ectoderm of Swiftia exserta which the 
increased surface area provided by numerous microvilli may encourage. As the bacteria enter the ectodermal cells they will encounter an array of quinones or quino-proteins (fig. 1b). Figure 6 in chapter 3 demonstrates a high concentration of quinones or quinoproteins in the thin outer ectoderm of the octocoral. These quinones, organic compounds with strong oxidative capacity, are capable of considerable damage to bacteria by oxidizing lipids, sugars (some found in DNA and RNA), and proteins.

The constitutive phagocytes, the primary immunocytes, that underlay the ectoderm engulf as demonstrated in chapter 3 , kill and digest any bacteria that pass through the thin ectoderm (fig. 1c). A second 'reserve' set of immunocytes deeper in the cell cords of the coenenchyme, that contain (pro)phenoloxidase, will be able to encapsulate any bacteria that reach this deeper level (fig. 1d). These immunocytes might also migrate to their targets since they are likely motile within the mesoglea. Robson in 1957 (per Bigger and Hildemann, 1982) conjectured that the mesoglea might serve as a conduit for amoeboid cells (akin to blood vessels for hemocytes in 'higher' metazoans). In many ways the progress made here to increase understanding of anthozoan immune reactions builds solely and directly on the 1982 review by Bigger and Hildemann, Olano's 2000 report on phagocytic activity in activated coenenchymal cells of Swiftia exserta, and on Metchnikoff's seminal 1892 lecture on the etiology of inflammation in immune reactions.

The potent antibacterial peptides present in cells throughout Swiftia exserta are likely to assist the host, as in other organisms, to eliminate pathogens. Some antimicrobial peptides are utilized to balance the host microbiome, but by morphology there is little evidence of a holobiome in Swiftia exserta - neither scanning nor 
transmission electron microscopy showed any microbes on, or in, the 10 randomly selected animals studied, mirroring the 2007 report about Porites compressa's relative lack of surface microbes by Johnston, but contradicting Brück et al. (2007). Unfortunately, further progress to fully identify and begin characterizing the antimicrobial peptides in Swiftia exserta has met with considerable hurdles - salt and concentration differences among starting materials interferes with electrophoretic separation and thus the main purification method. Both of the fully identified antimicrobial peptides from saltwater cnidaria, damicornin (Vidal-Dupiol, et al 2011) and aurelin (Ovchinnikova, et al., 2006), are both defensin-like in sequence and secondary structure. Confirming the identity of swiftin as a defensin-like peptide will strengthen the evolutionary pre-eminence of the defensin family of antimicrobial peptides.

The results presented in this dissertation provide a much-needed foundation to study the immune systems in (octo)corals. However, much work remains before we can truly appreciate the complex nature of immune reactions in these primitive metazoans direct follow-up experiments should include enzyme histochemistry during wound healing and grafting reactions and identifying the cellular effectors of wound healing and grafting reactions; determining the proteins involved in the self/non-self recognition reactions that underpin the grafting reactions; characterizing the signaling involved in both wound healing and grafting reactions; extending these studies to the immunological memory described in Swiftia exserta (Salter-Cid and Bigger, 1991); and finally establish the identity of swiftin. 


\section{REFERENCES}

Bigger, C.H., Hildemann, W.H., 1982. Cellular defense systems of the Coelenterata. In: Cohen, N., Sigel, M., (Ed.) The Reticuloendothelial System. Plenum Press, New York, pp. 59-87.

Brück, T.B., Brück, W.M., Santiago-Vazquez, L.Z., McCarthy, P.J., Kerr, R.G., 2007. Diversity of the bacterial communities associated with the azooxanthellate deep water octocorals Leptogorgia minimata, Iciligorgia schrammi, and Swiftia exserta. Mar. Biotech. 9, 561-576.

Johnston, I.S., Rohwer, F., 2007. Microbial landscapes on the outer surfaces of the reefbuilding coral Porites compressa. Coral Reefs. 26, 375-383.

Metchnikoff, E., 1892. Lecons sur la Pathologie comparee de l'Inflammation. Masson, Paris; reissued in English (1968) Lectures on the Comparative Pathology of Inflammation. Dover Publication Inc, New York.

Olano, C.T., 1993. Cellular aspects of alloimmunity and other responses in the gorgonian Swiftia exserta. Thesis (M.S.) Florida International University.

Olano, C.T., Bigger, C.H., 2000.. Phagocytic activities of the gorgonian coral Swiftia exserta. J. Invert. Path. 76, 176-184.

Ovchinnikova, T.V., Balandin, S.V., Aleshina, G.M., Tagaev, A.A., Leonova, Y.F., Krasnodembsky, E.D., Men'shenin, A.V., and V.N. Kokryakov. 2006. Aurelin, a novel antimicrobial peptide from jellyfish Aurelia aurita with structural features of defensins and channel-blocking toxins. Biochm. Biophys. Res. Comm. 348, 514-523.

Salter-Cid, L., Bigger, C.H., 1991. Alloimmunity in the gorgonian coral Swiftia exserta. Biol. Bull. 181, 127-134.

Vidal-Dupiol, J., Ladière, O., Destoumieux-Garzón, D., Sautière, P.-E., Meisterzheim, A.-L., Tambutté, E., Tambutté, S., Duval, D., Fouré, L., Adjerour, M., and G. Mitta. 2011. Innate immune responses of a scleractinian coral to vibriosis. J. Biol. Chem. 286, 22688-22698. 


\section{APPENDIX IV}

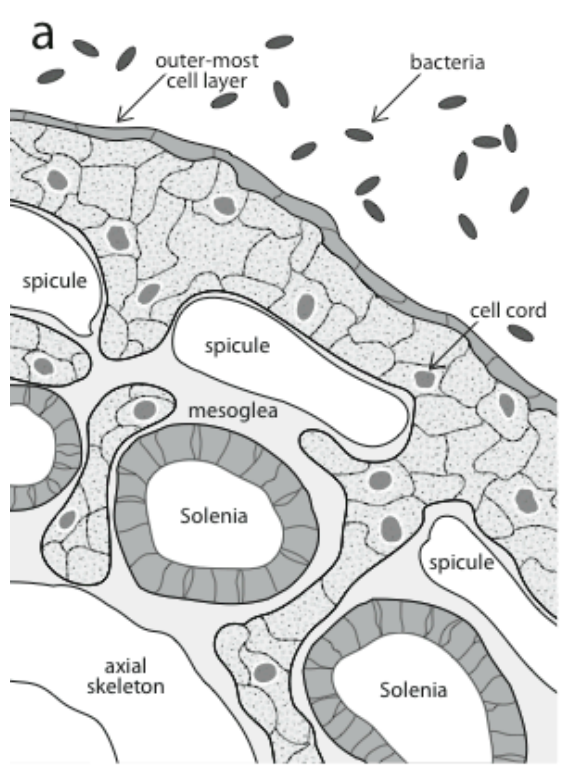

C
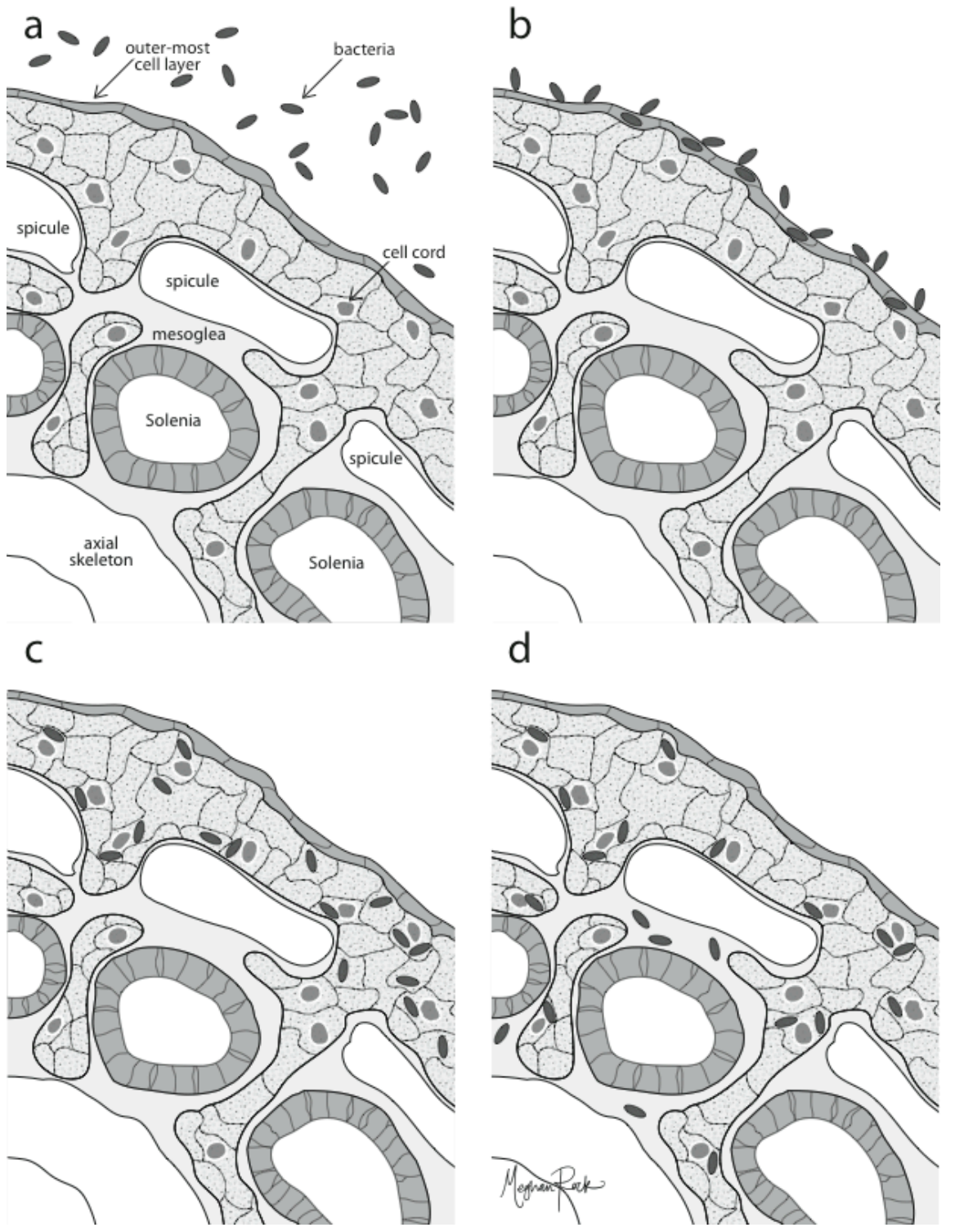

Figure 1. Schematic of Swiftia exserta anatomy and innate immune defenses. A) bacteria outside; b) contact and penetration into the ectoderm where quinones oxidize, modify, and possibly impair bacterial reproduction, some bacteria remain outside the animal (not pictured); c) modified or non-dividing bacteria are ingested by constitutive phagocytic immunocytes, while those remaining outside the animal are unaffected (not pictured); and c) second group of immunocytes has phenoloxidase to isolate (encapsulate) any microbes that have penetrated this layer, while the remaining bacteria outside of the animal (not pictured) are unaffected. 
VITA

Lorenzo P. Menzel

North Miami, FL 33181

EDUCATION

lorenzo.menzel@,fiu.edu

Ph.D. Candidate, Biology, Florida International University, Miami, FL 2013

B.S. Molecular, Cellular, and Developmental Biology, University of California, Los Angeles, CA 2004

\section{EXPERIENCE}

Visiting Researcher, Dr. Kym Faull lab, UCLA (August 2013)

Teaching Assistant, Florida International University

Cell Biology Lab, 2006

Biochemistry Lab, 2006

Evolution Lecture, 2012

\section{AWARDS}

Teaching Assistantship, Florida International University, 2006.

FIU MBRS-RISE BRI Grant, Summer 2008.

FIU MBRS-RISE BRI Grant, Summer 2009.

Travel Bursary, $11^{\text {th }}$ International Congress ISDCI, 2009.

SICB Charlotte Mangum Student Housing Award, 2012.

FIU GPSC Conference Funding to attend 2012 Annual SICB Meeting, 2012.

FIU GPSC Conference Funding to attend Microscopy \& Microanalysis, 2012.

SICB Charlotte Mangum Student Housing Award, 2013.

\section{PROJECTS}

$\mathrm{Ph}$.D. Dissertation, Aspects of Innate Immunity in the Carribean Octocoral Swiftia exserta

Juan Liuzzi, LPS effects inflammatory cytokine expression in hepatocytes

M. Alejandro Barbieri and Sushmita Mustafi, Effects of Dihydrolactone on P. aeruginosa Brittany Yusko, Quantification of mesotocin by ELISA 


\section{PRESENTATIONS}

1. Menzel, L.P., Bigger, C.H., 2013e. Enzyme histochemical identification of the potential "immunocytes" in the octocoral Swiftia exserta. Biomedical \& Comparative Immunology Symposium. March 7-8, 2013. Florida International University. Miami, FL (Talk).

2. Menzel, L.P., Bigger, C.H., 2013c. Antibacterial peptides from the Caribbean octocoral Swiftia exserta. Gordon Research Conference on Antimicrobial Peptides, Ventura, CA Feb 23-Mar 1, 2013. (Poster).

3. Menzel, L.P., Bigger, C.H., 2013b. Can enzyme histochemistry identify the immune cells of the octocoral Swiftia exserta? Integrative \& Comparative Biology. Vol 53(S1):E333.(Poster).

4. Menzel, L.P., Bigger, C.H., 2013a. Antibacterial peptides from the Caribbean octocoral Swiftia exserta. Integrative \& Comparative Biology. Vol 53(S1):E144. (Talk).

5. Menzel, L.P., Stein, B., Bigger, C.H., 2012c. Ultrastructure of Swiftia exserta, a gorgonian octocoral from the western Atlantic. Microsc. Microanal 18(S2):80 (Talk).

6. Menzel, L.P.Bigger, C.H., Antimicrobial activity in aqueous extracts of the Caribbean octocoral Swiftia exserta. ISDCI $12^{\text {th }}$ Congress. July 9-13, 2012. Fukuoka, Japan (Poster).

7. Menzel, L.P., Stein, B., Bigger, C.H., 2012a. Morphology and histology of the gorgonian coral Swiftia exserta. Integrative \& Comparative Biology. Vol 52(S1):E120. (Talk)

8. Menzel, L., Quirke, J.C.K, Quirke J.M.E., 2011 Following in the footsteps of Domagk: Photographic demonstrations of the synthesis of prontosil and bioassay of its degradation products. 2011 ACS Meeting, Aug 28, 2011. Denver, CO. (Poster)

9. Menzel, L.P., Bigger, C.H., 2009 Initial characterization of an agglutinin from Swiftia exserta, a gorgonian octocoral. ISDCI $11^{\text {th }}$ Congress, June 29-July 7, 2009, Prague, Czech Republic. (Poster) 